\title{
Santuarios y Fortalezas. Cuestiones de indigenismo, heleniza- ción y romanización en torno a Emporion y Rhode (S. VI - I A.C.).
}

Joaquín Ruiz de Arbulo

Universitat de Lleida

\begin{abstract}
En cuanto a los iberos, el hecho de que se paseen con ropas de tragedia ricamente decoradas y que lleven túnicas caídas hasta los pies no les impide hacer la guerra con vigor. Por el contrario los massaliotas, que portan los mismos vestidos que los iberos, tienen costumbres afeminadas y su falta de energía interior, tanto como su gusto por la molicie, hacen su comportamiento del todo inconveniente; de ahí el conocido proverbio: "que puedas tu remar hacia Massalia" (Ateneo, XII, 523 b-c), s. II d.C.
\end{abstract}

\section{Resumen}

Se presentan diversas cuestiones de la relación entre los modelos helénicos de las colonias de Emporion y Rhode y las costumbres indígenas evidenciadas en los yacimientos ibéricos de su entorno. Los cultos de Artemis y Apolo como dioses protectores de la emporía arcaica de los foceos, el urbanismo de Rhode en el siglo III a.C., los cultos emporitanos, la interpretación del yacimiento de Pontós, la mezcla de cultos griegos y celtas en Ullastret y Pontós y un cálato excepcional en un campo de silos al pie de S. Julià, se estudian como evidencias de esta relación. En el siglo II a.C., Roma implantará un nuevo orden político y económico del que Emporion será la gran beneficiada.

\section{Abstract}

In this paper we present different aspects of the complex interaction between the Hellenic models found in the colonies at Emporion and Rhode, and the indigenous customs as shown in the Iberian sites surrounding them. As evidences of this interaction we will study the cult of Artemis and Apollo as protector deities of the archaic Phocean emporía, the urbanism in Rhode during the 3rd century $\mathrm{BC}$, the cults at Emporion, the interpretation of the lberian site at Mas Castellar de Pontós, the blend of Greek and Celtic cults in the indigenous sites at Ullastret and Pontós, and an unique decorated lberian pottery kalathos found in an underground grain silos field close to the site at $\mathrm{S}$. Julià de Ramis. During the 2nd centrury BC Rome imposed a new political and economic order in which Emporion would become the greatest beneficiary.

\section{MAsSAlia, UN CENTRo de ACUlturación}

En su descripción de la Galia, escrita en torno al año 18 a.C. y basada en textos de Posidonio, Artemidoro, Polibio y Asinio Polión, Estrabón dedica una amplia atención a la vieja fundación focea de Massalia (cf. Hermary, Hesnard, Treziny 1999). Al describir la ciudad, de imponentes murallas, levantada sobre un anfiteatro rocoso que rodeaba la bahía portuaria, Estrabón incluye la mención de una acrópolis con dos templos dedicados respectivamente a Apolo, el dios común de los jonios, y a la Artemis de Éfeso, cuya presencia explica a través de la leyenda fundacional de los massaliotas. Recordaba esta tradición como entre los griegos de Focea, partidos en época arcaica a la gran aventura colonizadora que debía hacerles salir de la miseria, se habría corrido la voz de tener que dirigirse a Éfeso y tomar como guía a quien decidiera la gran diosa 
Artemis. Al llegar sus naves a la ciudad y comenzar la búsqueda, Aristarca, una rica aristócrata efesia, recibiría en sueños de la diosa

"la orden de embarcarse con los foceos tomando con ella una maqueta reducida del santuario...Cuando los colonos llegaron al término de su expedición, construyeron el santuario y honraron a Aristarca con la mas alta dignidad haciéndola sacerdotisa. En todas las colonias de Massalia, se venera a Artemis por encima de cualquier otra divinidad y se conserva su ídolo con la misma actitud y su culto con los mismos ritos que en la metrópolis" (Estr., IV, 1, 4).

Estrabón describe a continuación la constitución aristocrática que regía desde siempre la vida de la ciudad, con leyes "jonias" expuestas en público, los dos consejos de gobierno dirigidos por tres magistrados supremos; el territorio, rocoso y accidentado, escaso en cereales pero rico en cultivos intensivos de olivos y viñedos (que sabemos económicamente muy rentables). Pero una carencia en cereales era siempre peligrosa y los massaliotas pudieron superarla gracias a su dominio en la navegación:

"En sus inicios, los massaliotas supieron contar más con el mar que con la tierra, y aprovecharon con preferencia las ventajas naturales que ofrece la navegación. Pero más tarde, su coraje y energía les hizo bastante fuertes para añadir a sus posesiones algunos de los valles que les rodean. Desplegaron en esta conquista la misma fuerza militar empleada en la fundación más antigua de las ciudades que les sirven de bastiones, unas de la parte de Iberia contra los iberos, a los cuales además transmitieron su culto nacional de la Artemis de Éfeso, enseñándoles a sacrificar según los ritos griegos...” (Estr. IV, 1, $5)$.

Su habilidad en la construcción de naves y máquinas de guerra y los servicios prestados a Roma durante la Segunda Guerra Púnica, favorecerían la intervención romana a fines del siglo II a.C. El cónsul C. Sextio Calvino, tras vencer a los salios y establecer una guarnición militar permanente en Aquae Sextiae, habría expulsado de las costas próximas a las tribus galas "regalando a los massaliotas todo el terreno evacuado". Estrabón observa en último lugar la antiquísima alianza entre ambas ciudades como atestiguaría el hecho de que la imagen de la diosa Diana del gran santuario de los plebeyos en el Aventino siguiera el modelo de la Artemis massaliota.

A pesar del error cometido por la ciudad al seguir el partido de Pompeyo y enfrentarse a César, el dictador habría respetado los privilegios massaliotas manteniendo su autonomía (y de las ciudades de ella dependientes) respecto a los prefectos romanos. Finalmente, en el contexto de la nueva pax romana, Estrabón describe el singular papel de aculturación que en el siglo I a.C. jugaba Massalia entre los distintos pueblos del sur de la Galia:

"Desde la guerra civil entre César y Pompeyo, los massaliotas que habían abrazado la causa del partido perdedor, perdieron la mayor parte de su prosperidad. Subsiste sin embargo entre sus habitantes algunos rasgos de su antiguo espíritu emprendedor, en particular en la construcción de máquinas de guerra y armamento naval. Por otra parte, como los bárbaros del interior del país son cada vez más accesibles a la civilización y abandonan la guerra para dedicarse a las actividades urbanas y la agricultura bajo la influencia de la dominación romana, con más razón los massaliotas no sabrían mantener entre ellos un gusto vivo por estas actividades de las que hemos hablado. Una prueba la tenemos en su situación actual: todos los ciudadanos de buena familia se dedican al arte de la oratoria y a la filosofía, hasta el punto que su ciudad servía muy recientemente como escuela para los bárbaros, haciendo de los galos unos filo-helenos hasta el punto de redactar únicamente sus contratos en griego. Hoy, la ciudad ha sabido a su vez persuadir a los romanos más ilustres para venir a estudiar bajo sus muros mejor que a Atenas si desean de verdad instruirse. Viéndolos residir allí, los galos orientan voluntariamente sus ocupaciones hacia un género de vida análogo al suyo. Y todo esto pasa no tan solo por la decisión de individuos aislados, sino realmente por una razón pública: acogen a sofistas que son retribuidos unos por particulares y otros por el tesoro público, y otro tanto ocurre con los médicos... " (Estr., IV, 1, 5)

El lector debe pues acudir a este libro IV de Estrabón para aclarar las dudas acumuladas por la lectura del anterior libro III, dedicado íntegramente a la descripción de Iberia. Cotejadas las noticias que el de Amasia va suministrando en sus diferentes libros, emerge una primera noticia de interés etnográfico: a través de sus "bastiones" en Iberia, establecidos ya en la época arcaica, los massaliotas habrían transmitido a los iberos su culto nacional a la diosa Artemis, incluyendo la "enseñanza" de los ritos y sacrificios característicos.

\section{EMPORION Y RHODE.}

Desgraciadamente, las noticias recopiladas por Estrabón sobre la colonización focea en Iberia, no llegan ni mucho menos a tener la amplitud y detalle del relato sobre los massalio- 
tas. La mención de mayor entidad se refiere a la descripción de las colonias de Emporion y Rhode, en el golfo de Rosas:

"Emporion es fundación de los massaliotas y dista del Pirineo y de la frontera entre la Iberia y la Céltica unos 200 estadios. Y toda esta costa es fértil y tiene buenos puertos. Por allí está también la pequeña ciudad de Rhodos, cuyos habitantes vienen de Emporion pero que habría sido fundada, dicen, por los rodios. También aquí y en Emporion hay el culto de la Artemis de Éfeso, lo que explicaré en lo que diré sobre Massalia. Los emporitanos vivían antes en una islita delante de la costa que hoy se llama Palaiápolis, pero hoy viven ya en tierra firme. Emporion es una ciudad doble, estando dividida por una muralla, teniendo antes como vecinos algunos indicetas, que a pesar de que conservaban su administración propia quisieron tener una muralla común con los griegos para su seguridad, resultando así una fortificación doble, dividida por una muralla media. Pero con el tiempo se unieron en un solo estado, compuesto por leyes bárbaras y griegas, como sucede también en otras muchas ciudades.

Corre por allí cerca también un río que viene del Pirineo y cuya boca sirve de puerto a los emporitanos. Los emporitanos son hábiles en la fabricación de lino. Como territorio tienen el interior y este en partil es fértil y en parte solo cría junco de la especie palúdica, de poca utilidad. De esto recibe su nombre el Campo Juncario. Algunos (emporitanos) habitan también los altos del Pirineo hasta el

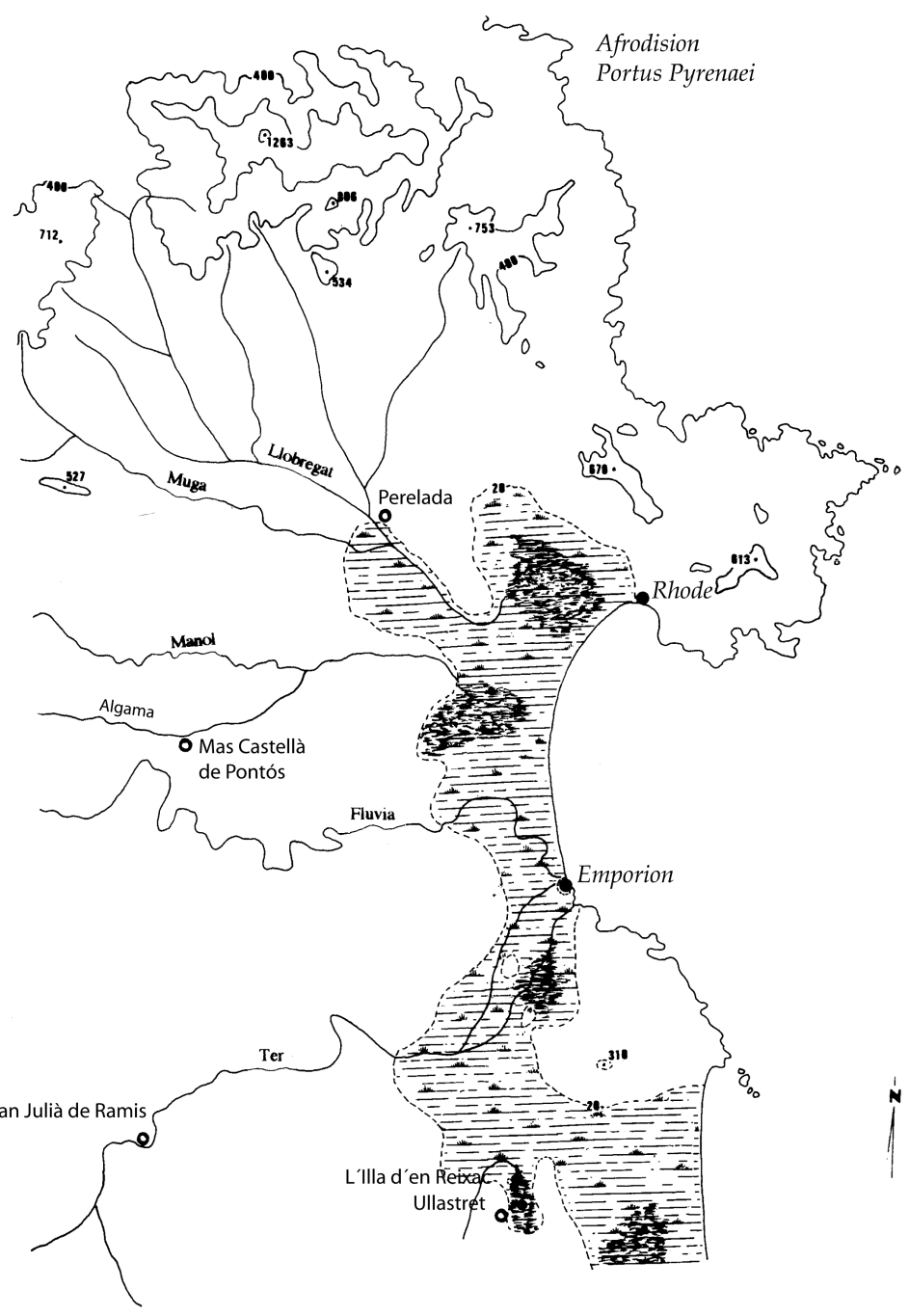

monumento de Pompeyo, por donde pasa la vía que llaman 'exterior' y que va de Italia a Iberia" (Estr. III, 4, 8-9).

Como ocurriera en Massalia, Estrabón describe Emporion y Rhode cotejando una tradición anticuarial referida a los orígenes de ambas ciudades
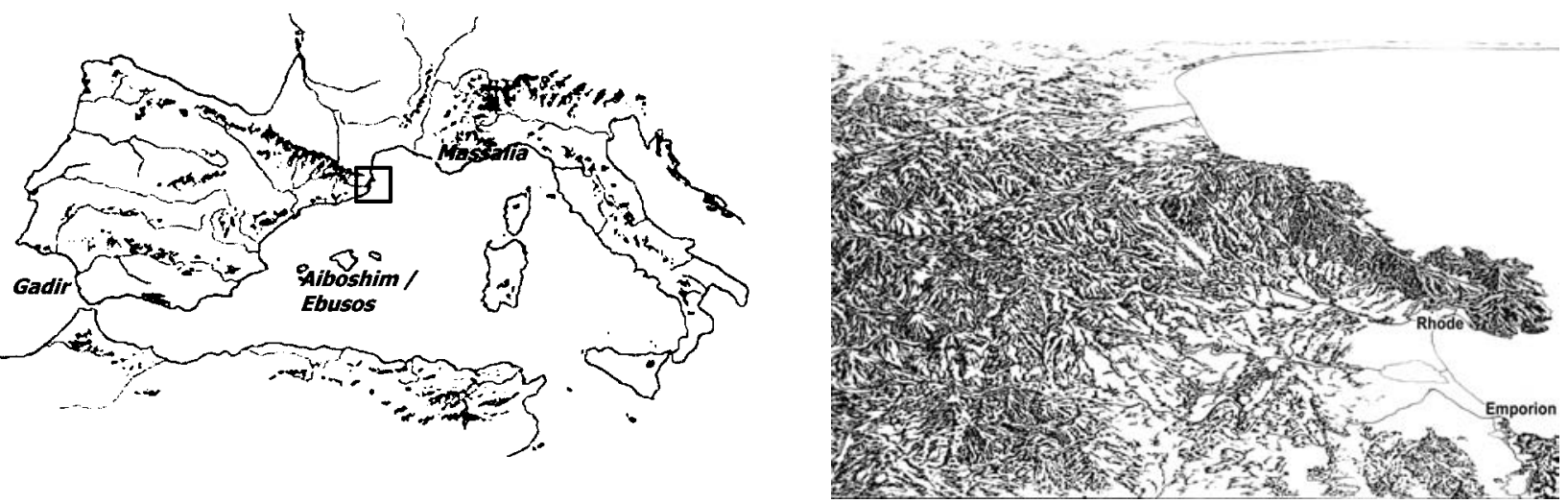

Fig.1.- Plano de situación con las grandes paleounidades físicas y restitución del relieve (dibujos autor). 
con otros autores más próximos a su época, ya que se mencionan los trofeos de Pompeyo levantados en el 71 a.C. junto a la gran vía romana sistematizada a fines del siglo II a.C. Pero en el largo proceso histórico que condujo desde el siglo VI a.C. hasta esta realidad histórica tardorepublicana nos queda la duda, a falta de otra información, de saber si los santuarios de Artemis citados en Emporion y Rhode jugaron realmente en época arcaica ese papel misionero que les atribuye Estrabón en la transmisión de creencias y ritos hacia las comunidades iberas del entorno. Y también, en el otro extremo temporal del discurso histórico, si la Emporion tardorepublicana, convertida por Roma en guardiana de la región, pudo ser también un centro de aculturación con un papel equivalente (aunque lógicamente a una escala mucho menor) al ejercido por Massalia entre los galos meridionales.

En lo que respecta al papel de los Artemisia, la cita de Estrabón ha sido tan difícil de comprobar arqueológica e históricamente como la propia ubicación exacta en tierras levantinas del más famoso de sus santuarios en Hemeroskopeion / Dianion (Estr., III, 4, 6). Ahora bien, Emporion y Rhode deberían permitirnos mayores precisiones, pues aquí sí que podemos confrontar una dilatada investigación arqueológica en ambas ciudades con los resultados obtenidos en los yacimientos iberos de las comarcas interiores. Una región pues idónea para comprobar el sentido de las citas de Estrabón en relación a los "modos de contacto y procesos de transformación” entre colonizadores e indígenas que estudiara el congreso de Cortona, cuyas páginas nos parecen siempre de plena actualidad (Modes de contact 1983).

En 1993, dos breves síntesis de A. Martin y E. Sanmartí abordaron la cuestión de la iberización en torno a Emporion y Rhode. El balance de la información disponible era sin embargo mucho menor al que por aquellos años se conocía en el entorno de Massalia, con ocasión del gran congreso de 1990 (Bats et alii 1992; Voyage en Massalie 1990). Afortunadamente, la situación en el 2004 es ya otra muy diferente. Las excavaciones intensivas de larga duración realizadas en los principales yacimientos empordaneses, exposiciones (Cabrera y Sánchez 2000) y diversas reuniones científicas de síntesis (Cabrera, Olmos, Sanmartí 1994; Buxó y Pons 1999; Buxó y Pons 2000; Cabrera y Santos 2000; Martin y Plana 2001), hacen que hoy resulte arduo poder leer de forma detallada todo lo publicado en los últimos diez años sobre Emporion, Rhode y los principales yacimientos del mundo ibero indiceta: Perelada, Mas Castellar de Pontós, Ullastret / Illa d’en Reixach,
Begur, Porqueres y S. Julià de Ramis, por citar únicamente los principales yacimientos.

En las páginas siguientes vamos a intentar destacar diversas cuestiones referidas a esta interacción entre comunidades. Prevenimos al lector que vamos a hacerlo siguiendo un guión que ya hemos publicado anteriormente (Ruiz de Arbulo 2000) pero que ahora intentaremos matizar y ampliar, extrayendo nuevas conclusiones.

\section{SANTUARIOS Y EMPORÍA DURANTE EL ARCAISMO.}

Resulta evidente que una ciudad denominada Emporion, el mercado, no pudo nacer como una empresa colonizadora de un grupo de guerreros y mujeres desesperados bajo el liderazgo de un oikista con personalidad y méritos destinados a una futura heroización. Los relatos míticos "conquistadores" propios de las fundaciones dorias en Italia dejaron paso en Occidente a una dilatada experiencia de tomas de contacto entre los comerciantes marítimos itinerantes y las poblaciones indígenas costeras. Fue ésta la emporía aristotélica, el tráfico marítimo de redistribución inventado por los navieros aristócratas del Orientalizante practicantes del "comercio del don" recogido en los relatos de Homero y Hesíodo (Mele 1979; Ruiz de Arbulo 1999, 16-17 con bibl.; Domínguez Monedero 2001).

En Emporion, los ajuares de las necrópolis arcaicas y las nuevas estratigrafías de la Neápolis evidenciaban ya en los años 80 la presencia de un asentamiento indígena del Bronce Final, frecuentado libremente en los inicios del siglo VI a.C. por mercaderes marítimos portadores de materiales semitas, etruscos y griegos con cronologías algo posteriores a las documentadas en Massalia y el comercio etrusco en el Languedoc (Sanmartí 1992). Las nuevas excavaciones realizadas en los años 90 en diferentes puntos de $\mathrm{S}$. Martí d'Empúries, la Palaiápolis de Estrabón, refrendan esta imagen proporcionando nuevas evidencias estratigráficas del poblamiento durante el Bronce Final y más tarde del Primer Hierro en los inicios del siglo VI a.C., con la llegada de ánforas fenicias y etruscas, cántaros de bucchero nero, vasos corintios, copas jonias y cerámicas grises a torno (Aquilué et alii 1999; Aquilué et alii 2002).

Respecto a las características de este primer hábitat indígena todavía se encuentra inédita una magnífica necrópolis tumular del Bronce Final, excavada parcialmente como urgencia a fines de los años 90 en la margen derecha de la desembocadura del Ter Vell y cuyas urnas, extraidas con sus contenidos, esperan todavía almacena- 
das en el MME su análisis individualizado. Nada podemos concretar sobre el origen étnico de los mercaderes que en los inicios del siglo VI a.C. llevaron hasta Emporion esta variedad de productos mediterráneos, pero resulta evidente que sus puertos de origen al navegar frente a las costas empordanesas fueron esencialmente dos: al sur la Aiboshim / Ebusos fenicia, necesariamente activa desde los primeros contactos fenicios con el sur peninsular (Ruiz de Arbulo 1998 a), y al norte la nueva fundación focea de Massalia, intermediaria de los contactos con los puertos etruscos (Cabrera, Santos 2000). completamente como una invención tardía (Domínguez Monedero 1990; Santiago 1995; Pena 2000); una más de las creaciones literarias de los geógrafos y etnógrafos del helenismo tardío para explicar una omnipresencia griega en las costas del Occidente mediterráneo anterior a la gran expansión romana e itálica tardo-republicana.

Pero aceptando estos argumentos que encontramos convincentes, también deberíamos reconocer que los navegantes exploradores del arcaismo conocían plenamente su oficio. En el

En el momento en que estos contactos pasaron a realizarse de forma estable surgiría una primera y básica necesidad. Para ser realmente operativos, los mercados de playa estacionales propios del comercio detallista de cabotaje, precisaban disponer en las diferentes costas de puertos de redistribución. Estos lugares debían ser bahías abrigadas, en lo posible de aguas profundas, donde pudieran fondear sin problemas los pesados cargueros redondos de altamar (gauloi); unos puertos donde almacenar los productos que pudieran luego ser distribuidos por las costas

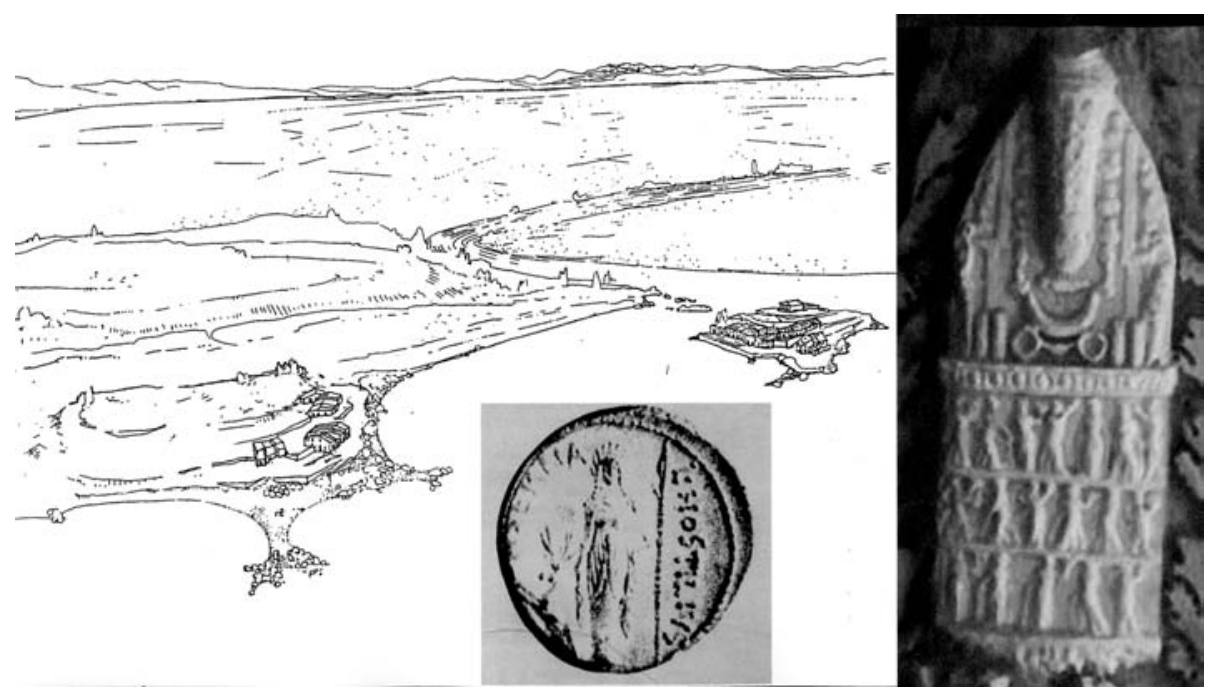

Fig.2.- Ilustración de Emporion durante la época arcaica con los primeros edificios estables del mercado portuario ahora presidido por el Artemision massaliota (dibujo de R. Mar, en Mar y Ruiz de Arbulo 1993). Se plantean dos posibilidades para imaginar el aspecto de la imagen de culto, ya fuera como la Artemis / Diana del santuario romano del Aventino (moneda de L. Hostilius) o como un betilo de inspiración oriental como la Artemis de Pergé.

vecinas por medio de

barcas más ligeras movidas a vela y remo (akatia, hippoi), rápidas y maniobrables, capaces de remontar estuarios y explorar las costas sin miedo a bajíos y escollos. Unos puertos, en fin, consolidados por el uso como asentamientos estables, permitiendo la invernada de los navegantes, el almacenamiento de los productos y los tratos comerciales a crédito.

En el golfo de Rosas, el único puerto así es... la propia Rosas. Esta evidencia que desde la náutica resulta irrefutable ha sido siempre para nosotros la explicación para entender la leyenda fundacional de los rodios empordaneses, ligada a navegantes venidos de Rodas "antes de las Olimpíadas", según un mito nacional recogido por Estrabón (XIV, 2,10) en la propia Rodas. Una tradición que los estudios más recientes desde el punto de vista literario han desestimado establecimiento de una ruta marítima estable por el golfo de Rosas el primer punto "controlado" por los navegantes fue necesariamente la ensenada abrigada al norte del golfo, protegida por el cabo Falcó, y en segundo lugar, o si preferimos de forma contemporánea, la situación inmejorable del islote o tómbolo de S. Martí, en la costa sur del golfo, respecto a las paleodesembocaduras próximas de los dos principales ríos de la región: el Ter y el Fluvià (Ruiz de Arbulo 1984; Mar y Ruiz de Arbulo 1993).

Los navegantes arcaicos debieron pasar muchas veces junto a las costas del Empordà antes de poder establecer enclaves permanentes. $\mathrm{Y}$ en esos viajes debieron ocurrir todo tipo de situaciones. Valga para imaginarlas un bello ejemplo mitológico: los argonautas de Jasón, bregados en mil aventuras, de regreso de la 
Cólquide y tras costear Creta, se pierden de noche cerrada en una costa extraña con riesgo cierto de naufragio, el fin más temido para cualquier marino:

"Pero en seguida, mientras navegaban sobre el gran abismo del mar de Creta, los atemorizó la noche que llaman infernal. En esa noche funesta no se distinguían las estrellas ni los destellos de la luna... y ellos ni siquiera sabían si eran llevados por el Hades o por las aguas...Entonces Jasón alzando los brazos clamaba a Febo (Apolo) en voz alta invocando su protección y en su angustia le brotaban lágrimas. Muchos regalos, incontables, prometió llevar a Pito (Delfos), muchos a Amiclas (cerca de Esparta) y muchos a Ortigia (Delos). Y tú, Letoida, atento bajaste del cielo rápidamente a las rocas Melantias que se hallan en medio del mar... A la vista de ellos apareció entonces una isla minúscula de las Esporades cerca de la pequeña isla de Hipuris. Allí echaron anclas y se detuvieron. En seguida brillaba la naciente aurora; y ellos en un bosque umbroso construyeron a Apolo un espléndido recinto y un umbrío altar, invocando a Febo resplandeciente a causa de su visible resplandor. Y llamaron Ánafe a la escarpada isla poque Febo la hizo aparecer ante ellos en su tribulación. Y ofrecían sacrificios de cuanto los hombres disponen para ofrecer en una costa desierta. Por eso, cuando las siervas feacias de Medea los vieron hacer libaciones de agua sobre tizones ardientes, entonces ya no podían contener la risa en su pecho como quienes siempre en casa de Alcínoo contemplaban copiosos sacrificios de bueyes..." (Apolonio de Rodas, Argonáuticas, IV, 1694-1724, extractado, los paréntesis son nuestros)

Frente a unos elementos ante los cuales la fuerza y las armas de nada sirven, el héroe llora sin rubor, y suplica a Apolo prometiendo dones en sus más famosos santuarios. La divinidad les asiste y encuentran un pequeño fondeadero seguro. La piedad exige entonces como agradecimiento levantar un santuario, es decir un recinto sacro (témenos) cercado por un muro (períbolos) donde se levanta un altar de sacrificios (bomós). Desde Homero, la tradición literaria helénica es rica en descripciones sobre los bóvidos, ovejas, cabras y cerdos ofrendados ante el altar, con vísceras quemadas y consumidas inmediatamente en comunión por los sacrificantes. Éstos pudieron ser un grupo reducido o bien las multitudes reunidas ante una de aquellas selectas hecatombes de bueyes que habrían contemplado a menudo (imagina el lector) las esclavas feacias en el mítico palacio real de Alcinoo. Pero el poeta recuerda también que en una isla desierta la pie- dad tan solo exigía el cumplimiento del gesto ritual: una simple libación de agua sobre los tizones encendidos en el altar, lo que despierta la broma de las cortesanas. No así la promesa en voz alta del héroe, que deberá ser cumplida como exvoto tras su regreso, sano y salvo, al hogar.

Los puntos de mayor peligro a lo largo de las costas, aquellos otros considerados útiles por su relieve destacado para reconocer una posición náutica y los que señalaban la proximidad de fondeaderos seguros y puntos de aguada se fueron así poblando de una "geografía sagrada", conocida, respetada y mantenida en uso por las comunidades de marineros (Ruiz de Arbulo 2000; Ferrer 2002). Un proceso al que los indígenas habitantes de las costas no pudieron ser indiferentes. El santuario de Afrodita, enclavado en una cala indeterminada junto a la cara norte del cabo de Creus (¿cerca de la actual Port Vendres?), resulta un buen testimonio de esta necesidad en relacion a la travesía, siempre peligrosa, del gran golfo galo en dirección noreste (Ruiz de Arbulo 1991; Riu en prensa).

En el Afrodision del Pirineo, los necesarios sacrificios previos no solo eran útiles para asegurar la protección de los dioses, sino que permitían además poder observar con calma el estado del tiempo y sus contrastes antes de la travesía; el consejo que encontramos todavía hoy en las instrucciones náuticas de los Derroteros $(1945,41)$ : "los prácticos en dichas travesías prefieren siempre, y en cualquier situación, atracar la costa española para entrar en el golfo de León”. La importancia singular del lugar la tenemos contrastada al conocer por Livio $(34,8)$ la presencia de un portus Pyrenaei donde el cónsul Catón concentró su flota de guerra en el 195 a.C. antes de atacar a los iberos rebelados en torno a Emporion y Rhode, y cuando más tarde Estrabón (IV, 1, 3) nos describe el santuario convertido en el límite fronterizo y mojón geográfico de distancias para la costa de la provincia narbonense.

En los contactos entre navegantes e indígenas tan solo la religión podía revelarse como un mecanismo efectivo y aceptado por todos. Hasta bien avanzada la época moderna una costa ha sido siempre un espacio inseguro y peligroso, con un tiempo de reacción muy limitado en caso de aproximación enemiga por el mar o respuesta hostil desde tierra a la llegada de un barco. Y por ello se crearon los puertos comerciales presididos por santuarios empóricos, garantes de la paz y la neutralidad, del cumplimiento de los pactos y del seguro almacenaje de los productos (Ruiz de Arbulo 2000). 
Una de las primeras reglas del tráfico marítimo en época arcaica fue la sylé o derecho de represalia: conseguir el saldo de la deuda no pagada, ya fuera con la carga de un compatriota del deudor e incluso con una actividad corsaria directamente dirigida contra los intereses de su ciudad. Contra esta práctica se desarrollaron entre ciudades tratados específicos de asylie, o bien se otorgaba esta pregorrativa de protección y asistencia a determinados santuarios, como el de Melkart en Tiro y el de Artemis en Éfeso (Van Berchem 1960; Velisaropoulos 1989). Toda nación antigua respetó como inviolables los témene sacros, propiedad directa de las divinidades que en ellos moraban y cuya protección se ampliaba a las instalaciones cercanas que dependían de una u otra forma de los mismos. Sabemos además que a partir del siglo VI a.C. el trato comercial de una cierta complejidad se basaba en contratos y préstamos realizados a crédito ante testigos. Para tales actos, tan solo los juramentos ante un altar consagrado garantizaban los cumplimientos.

El carácter de las divinidades garantes de los distintos empória dispersos por las costas mediterráneas fue en extremo variada y compleja, ya que la primera característica de los mismos fue precisamente su carácter abierto (Bresson 1993). Los cultos de los mercaderes estuvieron protagonizados básicamente por sus respectivos "panteones nacionales", en los que podemos evidenciar la existencia de dos esferas de competencias muy concretas: en primer lugar el santuario nacional en la polis, definido como entidad económica, reguladora de tributos y tasas y con ello acumuladora de bienes y capitales (Hera en Samos, Artemis en Efeso, Melkart en Gadir, etc.). La tributación sacra estaba siempre justificada por la necesidad de culminar el negocio efectuado asegurando un feliz viaje de regreso y para asegurarlo el pago de un diezmo o décate era una práctica generalizada. En segundo lugar, el santuario nacional emplazado en suelo extranjero era ante todo un centro de albergue y reunión para los compatriotas, a la vez que un lugar de apoyo para sus negocios. Los templos de Naucratis resultan un ejemplo bien explícito para estas costumbres (Ruiz de Arbulo 1999, 26-29; Domínguez Monedero 2001, 238ss).

En Emporion, el relato coincidente que transmiten Estrabón y Livio $(34,9)$, de considerar el mercado de los foceos como un apéndice o barrio foráneo instalado junto a un gran establecimiento proto-indiceta de mucha mayor entidad y población, parece hoy en día una imagen poco probable. La investigación arqueológica de Ampurias conduciría mejor a pensar en un pro-

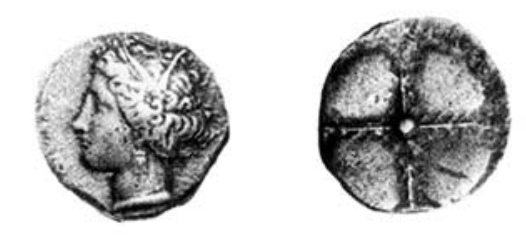

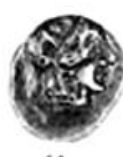

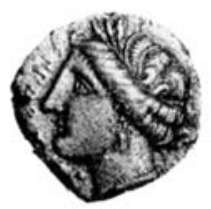

11
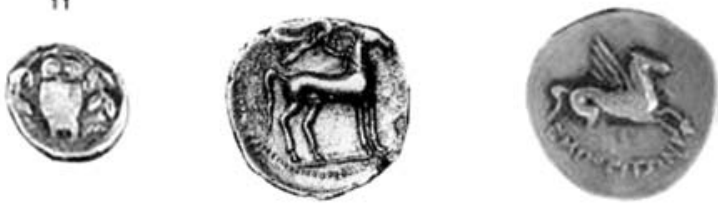

Fig. 3.- Arriba. Dracma de Rhode c. 325-300 a.C. Abajo. Acuñaciones emporitanas. De izq. a der. Obolo de imitación ateniense, c. 395-375 a.C.; Dracma emporitana de tipo púnico. Dracma emporitana de tipo helénico, ambas c. 325-300 a.C. Escalas desiguales.

ceso paulatino de concentración por parte de poblaciones dispersas por la región (el sinecismo arcaico de las ciudades griegas) que a lo largo del siglo $\mathrm{V}$ a.C. les habría conducido a reunirse en torno a los nuevos hábitats portuarios (Sanmartí 1993; Mar y Ruiz de Arbulo 1993, 119-139). En cualquiera de ambos casos, tan solo las divinidades y sus sincretismos podían actuar como símbolos aglutinadores.

Que los massaliotas exploraran las costas prospectando las posibilidades comerciales de los diferentes territorios llevando con ellos a sus dioses nacionales era no solo lógico sino también imprescindible. Pero además, Artemis y Apolo eran dioses magníficos para tender lazos de contacto, buscar apoyos, asegurar pactos y no despertar temores expansionistas. El Apolo de Delfos, generador, protector y guía de expediciones marítimas era común para todos los griegos y perfectamente asumible por los fenicios, pero además era un dios con un destacado papel oracular y curativo. ¿Qué príncipe indígena, sabedor de sus responsabilidades, podría resistir la tentación de una consulta y comprobar la fiabilidad de la respuesta divina?, ¿̇y qué madre no agradecería y divulgaría a todos la feliz curación de un hijo enfermo? El culto de Apolo introducido en el emporion de la Pompeya arcaica por parte de los calcidios de Cumas atestigua suficientemente esta técnica de contacto.

La Artemis de Éfeso fue como sabemos la expresión helenizada de la diosa madre anatólica, a la vez diosa de la fecundidad y de la naturaleza, de los animales y las fronteras, pero tam- 
bién de la vida cívica y social (Kahil 1979, LIMC s.v. Artemis, -Kahil-). Un concepto global de diosa protectora generalizado de una u otra formas por las distintas civilizaciones circunmediterráneas y fácilmente reconocible por todos. Ahora bien, si los massaliotas reproducían en sus fundaciones los ritos originales del gran Artemision de Éfeso, debemos recordar que éstos estaban fuertemente marcados por la influencia oriental que de nuevo menciona Estrabón con una noticia anticuarial:

"(Los efesios) tenían eunucos como sacerdotes, a los que llamaban megábyzoi, y siempre estaban buscando a personas de otros lugares dignas de semejante cargo, a las que tenían en gran estima, muchachas jovenes tenían que ejercer el sacerdocio con ellos. Actualmente se respetan algunas de sus normas otras menos, pero el santuario sigue teniendo derecho de asilía igual que antes, aunque las fronteras de la zona de este derecho han cambiado muchas veces... " (Estr., XIV, 22-23).

Una curiosa casta sacerdotal la de estos eunucos "extranjeros", a los que había que ir a buscar, para vivir después una cómoda vida de sacro recogimiento, rodeados de jóvenes vírgenes y lujos votivos. Desgraciadamente, carecemos totalmente de datos para imaginar si estos ritos orientales pudieron también trasladarse a Occidente. Por nuestra parte hemos llamado además la atención sobre la posibilidad de que esta política oficial de los massaliotas fundadores de Artemisia pudiera reflejar además una organización económica común, semejante a la que se ha propuesto practicaban los tirios con los templos de Melkart (Ruiz de Arbulo 2000, 31).

Cuando Estrabón (IV, 1, 6) describe que los romanos "habían dado al ídolo de Artemis eregido sobre el Aventino la misma actitud del de Massalia" estaba expresando una realidad anticuarial que podemos entender de una forma diferente. La fundación del templo que Livio $(1,45)$ atribuye a las reformas urbanísticas y sociales del rey Servio Tulio debería mejor atribuirse a los propios mercaderes massaliotas fundadores del santuario sobre el Aventino amparados por la philía del rey (Gras 1987; Scodellari 2003). La posición suburbana y preminente sobre el río, y la separación física respecto al puerto fluvial del Tíber presidido probablemente en el siglo VI a.C. por los dioses fenochipriotas Melkart y Astarté (Ruiz de Arbulo 1999, 24-25) nos muestra una vez más el funcionamiento de los mecanismos religiosos en los empória desde una perspectiva "nacional", que pudo ya tener durante el arcaismo los matices económicos y comerciales que conocemos en la época helenística.
La sociedad indígena debió asumir rápidamente el consumo del vino como mecanismo de relación social a través del banquete fenicio y del symposion helénico (cf. p.e. Ruiz de Arbulo 1996). El famoso "hallazgo cerrado" del oppidum de Ullastret que publicaran Arribas y Trías en 1961, sería una buena prueba. En un estrato de base sobre la roca, junto a las cerámicas a mano indígenas y fragmentos de ánforas "ibéricas" (fenicias occidentales?), apareció un servicio con piezas conservadas casi completas, compuesto por un ánfora etrusca Py 3B, una preciosa copa pseudojonia (de origen itálico) antropoprosopa, un cántaros de bucchero nero etrusco y una olpe pseudojonia pintada a bandas. Son piezas de orígenes diversos, que aparecen igualmente en la necrópolis arcaica de la muralla NE de Emporion y que hoy sabemos características de la emporía focea y massaliota del siglo VI a.C., con materiales que ha intentado caracterizar una reciente reunión (Cabrera y Santos 2000).

Podríamos también imaginar que las élites locales reclamarían a los mercaderes marítimos las nuevas necesidades de ropas, mobiliario, útiles de marfil, joyas mágicas y vajilla metálica. Pero nada parecido existe en el Empordà a los lujos del período orientalizante que contemplamos en Andalucía y Extremadura o en las posteriores tumbas principescas ibéricas meridionales. En comparación, la época arcaica paleoindiceta resulta de una pobreza patética, que debe reflejar, a pesar de la riqueza argentífera de los Pirineos (Ruiz de Arbulo 1984), una sociedad indígena con un grado menor de jerarquización social que impedía las abrumadoras concentra-

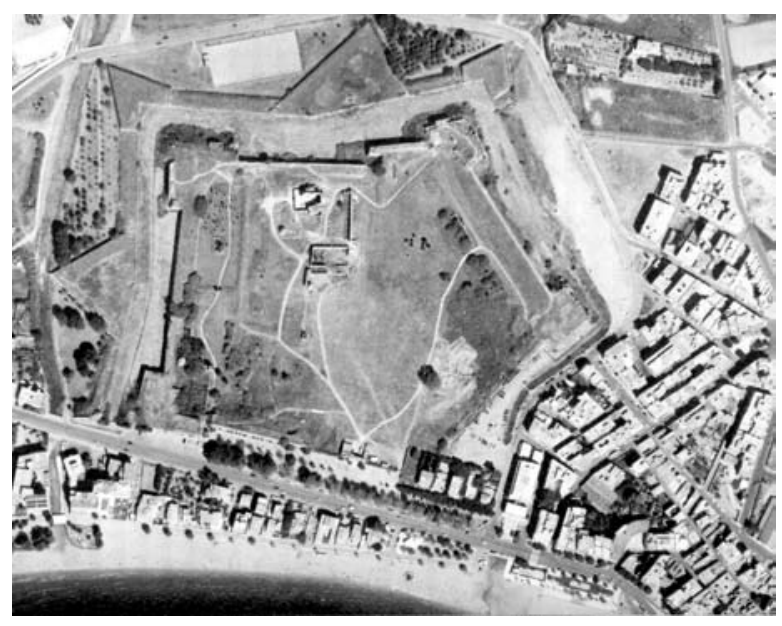

Fig. 4.-Vista vertical de la ciudadela de Roses, con los restos de la iglesia de Sta. María en la parte superior y el área excavada del barrio helenístico y la factoría tardo-romana en la parte inferior, a la derecha (foto Institut Cartografic de Catalunya, de De La Fuente 1998, 55). 
ciones de riqueza que contemplamos entre los "príncipes" del Orientalizante en Etruria o Tartessos.

El nacimiento de la sociedad ibérica indiceta es todavía un proceso muy mal definido en sus detalles. Las primeras casas rectangulares, construidas en adobe sobre zócalos de piedra, organizadas en hileras, con pavimentos y hogares domésticos, aparecen de forma casi contemporánea a principios del siglo VI a.C. en S. Martí d'Empúries (Emporion) y l'Illa d'en Reixac (Ullastret) mientras que los hábitats conocidos del Bronce Final corresponden siempre a cabañas dispersas (cf. Martin 1998). Y en esta fase proto-urbana que cubre la primera mitad del siglo VI a.C. se produjo una transformación esencial en el utillaje cerámico. Los contextos caracterizados por cerámicas a mano con presencia puntual de ánforas fenicias sudpeninsulares y ánforas etruscas junto a vajilla preciada como los cántaros etruscos, característicos del inicial "comercio de los regalos" (gifts trade), dejaron paso paulatinamente a un aumento de las importaciones de ánforas griegas y vajilla jonia oxidada y reducida de distintos orígenes, y junto a ellas las primeras producciones a torno "ibéricas" de cocción oxidante (¿locales?, cimportadas del Levante?) que poco a poco se irían haciendo mayoritarias hasta sustituir como vajilla doméstica a la cerámica a mano reducida (cf. evolución y estadísticas en Castanyer, Santos, Tremoleda 2000).

\section{LA ÉPOCA Helenística. Rhode Y EMPORION.}

A fines del siglo IV a.C., Rhode y Emporion, dos ciudades próximas, situadas en el mismo golfo y visibles una desde otra, eran dos poleis independientes, con territorios respectivos que

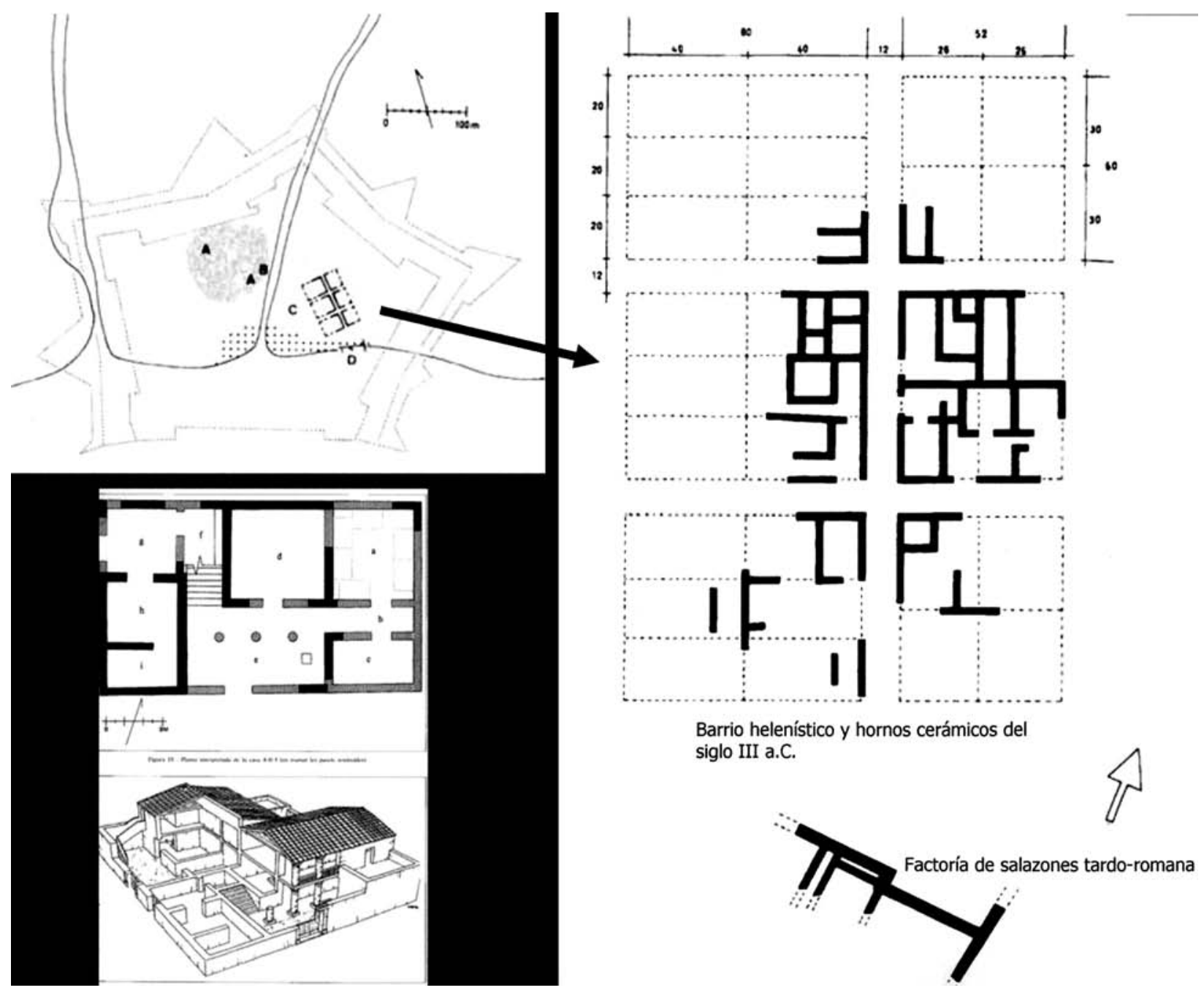

Fig. 5.- Modulación y restitución de las unidades residenciales en el barrio helenístico de Rhode, según D. Vivó (1996). 
no sabemos en lo político definir ni medir con precisión. En cambio, podemos restituir con cierto detalle las grandes unidades fisicas de un paleopaisaje en torno al golfo de Rosas sin variaciones fundamentales hasta época tardomedieval (Ruiz de Arbulo 1984; Mar y Ruiz de Arbulo 1993, 103-118). En línea con lo descrito por Estrabón, se trata de llanuras costeras de colmatación cuaternaria limitadas al norte por las últimas estribaciones del Pirineo y al oeste por sierras que progresivamente van ascendiendo de cota, con valles transversales formados por cuatro ríos principales: Muga, Manol, Fluvià y Ter (Fig. 1). Al llegar a la llanura aluvial, la falta de pendientes tornaba erráticos los cauces fluviales con la formación de grandes medios lagunares en un paisaje de marismas costeras: el casi estéril "campo de los juncos" (iounkarion pedion) de Estrabón.

Ambas ciudades emitieron de forma simultánea a fines del IV a.C. sendas acuñaciones monetales de dracmas de plata con símbolos distintivos. Rhode escogió como emblema parlante una rosa en vista vertical, con leyenda rhodeton, y una cabeza femenina imitando la Aretusa siracusana. Emporion, por su parte, inició sus acuñaciones de dracmas imitando sin ambajes los tipos púnicos del caballo parado, con leyenda emporiton y anverso con cabeza de Koré / Tanit coronada con espigas; pero pronto sustituyó su primera serie asumiendo igualmente el estilo helénico de la ninfa siracusana y sustituyendo el caballo parado por un canónico Pegaso alado de tipo corintio.

En realidad, Emporion había ya iniciado sus acuñaciones a mediados del siglo $\mathrm{V}$ a.C., siguiendo el ejemplo de Massalia y otras colonias foceas, con emisiones anepígrafas de plata fraccionaria y tipología arcaizante de motivos muy variados. A fines del s. V a.C. las series iban ya marcadas con las letras griegas EM o EMP. En los inicios del siglo IV a.C., la ocultación de 897 monedas de plata en un pequeño jarro de tradición jonia encontrado en la Neápolis emporitana en 1926 nos muestra un buen ejemplo de la política monetal empleada: 879 monedas corresponden a una misma emisión con anversos que presentan la cabeza de Atenea de perfil y reversos con la lechuza de frente entre dos ramas de olivo y las iniciales de la ciudad EM (Campo y Sanmartí 1991). Marta Campo ha datado esta serie monetal emporitana c. 395-375 a.C., copiando la moneda ateniense del siglo $\mathrm{V}$ a.C., una de las de mayor prestigio y difusión en los mercados griegos.

Las acuñaciones monetales nos muestran así superpuestas sus dos características: son cierta- mente emblemas políticos y nuevos símbolos parlantes de sus comunidades pero ante todo tenían que ser útiles económicos, reconocibles y aceptables en unos mercados abiertos a todo tipo de acuñaciones, con pesos y aleaciones fácilmente comprobables por vendedores y cambistas. En este contexto económico, la interpretación de los símbolos parlantes se hace compleja, puesto que recurrir a imágenes de las monedas con mayor prestigio se había convertido en una práctica habitual.

La divinidad femenina que preside los anversos en las nuevas dracmas emporitanas y rodias del siglo IV a.C. parece imitar ciertamente a la dama que aparece en las contemporáneas dracmas massaliotas. Pero éstas a su vez copiaban sin ambajes los anversos de las dracmas de la ciudad magnogreca de Terina (Brenot 1990). No obstante podemos intuir una imagen común. La dama massaliota tiende a interpretarse como imagen de la diosa nacional Artemis. Una identificación que también había propuesto M.J. Pena (1974) para las series emporitanas. La rosa de Rodas y el Pegaso de Corinto servirían así de símbolos identificadores acompañando a sus leyendas respectivas, mientras que la divinidad compartida amparaba el parentesco mítico (y ahora económico) entre las poleis.

\section{RHODE Y EL URBANISMO DEL "BARRIO HELENÍSTICO" EN EL SIGLO IV A.C.: LA ÉPOCA DE LAS FORTALEZAS COSTERAS.}

R. Santiago $(1995,61)$ ha llamado la atención sobre el error fonético cometido por los rodios empordaneses al acuñar en las dracmas el nombre de su comunidad -rhodeton-, ya que el dialecto griego hablado en Rodas mantuvo invariable hasta época romana los rasgos de su dialecto dorio original, con el etnónimo rhodaton, mientras que la letra alfa se convertiría en épsilon en los dialectos del grupo jónico-ático: rhodeton. La autora considera esto una prueba palpable de que los rodios empordaneses no pudieron ser "verdaderos" descendientes de rodios y lo contrasta con unas evidencias arqueológicas en el mismo sentido que resumimos acto seguido. Pero vaya primero una reflexión.

Por supuesto que los de Rhode eran unos falsos rodios en el siglo IV a.C., icuatro siglos después! de la mítica expedición. Si la aventura rodia en Occidente durante el siglo VIII a.C. tuvo efectivamente lugar fue tan solo eso, una serie de expediciones puntuales sin continuidad en el tiempo. Pero la creación de una leyenda fundacional necesitaba siempre una prueba, una pista en torno a la cual un poeta pudiera construir el 
mito. Necesariamente debía existir en Rhode algun elemento que permitiera a sus habitantes enriquecidos por el comercio y organizadores de su autonomía poder sistematizar (o inventar si lo preferimos así) su nombre y su historia. Por lo que sabemos del mundo antiguo, tan solo podemos imaginar que se tratara de venerables ofrendas votivas conservadas en un santuario. $\mathrm{Al}$ mismo tiempo, cuando Estrabón cita de nuevo la misma cuestión en su libro XIV al describir la ciudad de Rodas creemos que hay que tomar muy en serio esta leyenda nacional. Los rodios del siglo I a.C. eran los marinos de mayor prestigio, compiladores de la única legislación náutica utilizada y respetada por todos, y no tenían ninguna necesidad de crearse un imaginario mítico de forma gratuita.

Pero volvamos al Empordà. Los hallazgos arqueológicos referidos a la antigua $R$ hode se han realizado siempre en el interior de la gran ciudadela de Rosas levantada a partir del 1543 para hacer frente a las incursiones berberiscas. Una gran fortificación moderna que fue asediada en las principales guerras de los siglos XVII, XVIII y XIX (De La Fuente 1998). En el interior de la ciudadela, la paleotopografía del asentamiento antiguo corresponde a una colina costera (bajo la actual iglesia de Santa María) entre dos rieras cuyas golas formarían una pequeña vaguada delimitada por playas laterales permitiendo la puesta en seco de las embarcaciones (Puig et alii 1996).

Pero los sondeos estratigráficos realizados en torno a Santa María nunca han proporcionado materiales anteriores al siglo $\mathrm{V}$ a.C. A partir de esta evidencia y de la abundante presencia en el yacimiento de materiales massaliotas, A. Martin (1983) propondría considerar Rhode como una creación tardía de los massaliotas para oponerse a una Emporion demasiado autónoma (v. en último lugar Martin y Puig 2001, 58-59). Una posibilidad que explicaría pues la "invención" de una leyenda fundacional diferenciada.

Se trata de una propuesta razonable, pero que nunca hemos podido compartir (contra Ruiz de Arbulo 1984). Cuando F. Villard sistematizó en 1960 la ceramología de Massalia observó ya la autonomía del circuito comercial emporitano en los siglos V y IV a.C. respecto a los materiales presentes en Marsella. Pero esta "independencia emporitana", que acreditan suficientemente las acuñaciones monetales desde el siglo $\mathrm{V}$ a.C. no tuvo porqué implicar una hostilidad sino una mera complementariedad de áreas de mercado. En primer lugar por una razón de estrategia militar. Si los emporitanos hubieran significado cualquier tipo de rivalidad respecto a Massalia, ésta dispuso siempre de una fuerza militar y naval más que suficiente para "convencer" o simplemente "sustituir" a la élite local emporitana por otro grupo más favorable a sus intereses.

El segundo argumento afecta a las razones geográficas que ya hemos expuesto: el "puerto de escala" fue siempre Rhode y por ello no podemos entender la existencia de Emporion si quedaba abandonado el fondeadero principal del golfo. En tercer lugar, el criterio ceramológico nos parece incompleto: las importaciones massaliotas son ciertamente abundantes en Rhode, pero también estuvieron siempre presentes en Emporion. La práctica de la emporía, entonces y ahora, nunca permitiría rechazar un negocio.

Todo ello nos lleva a plantear otras posibilidades de interpretación. Creemos que los datos estratigráficos disponibles en torno a la iglesia de Santa María de Rosas son muy puntuales y en un lugar tremendamente condicionado por la ocupación humana continuada en los cuatro últimos siglos. Si algo ha podido afectar de forma radical a la paleo-topografía de un lugar es sin duda la construcción de los fosos, baluartes y cuarteles de una ciudadela artillada, activa y con guerras permanentes a lo largo de cuatro siglos. Por otra parte, hemos de recordar la existencia de asentamientos indígenas en las vertientes de las sierras situadas al norte del fondeadero, estudiados por E. Pons: una necrópolis tumular del Bronce Final en el Puig Alt y un pequeño hábitat cercano en la cueva del Cau de les Gilles, con presencia de facies cerámicas atestiguadas en Mailhac (Pons

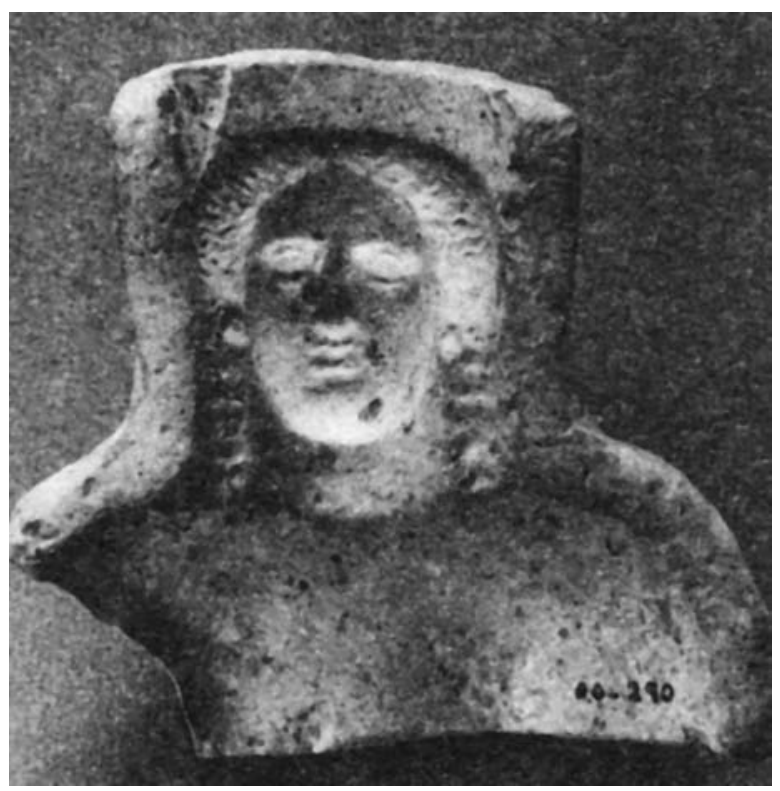

Fig. 6.- Talleres cerámicos del barrio helenístico de Rhode. Molde de pasta massaliota para realizar protomai (de Martin 1978). 
1984; Pons 2000, cit. por Martin y Puig 2001, 56).

Con ello, podemos justificar la existencia de un hábitat disperso en la Rhode de época arcaica mucho más amplio de lo que ahora imaginamos. El castillo de la Trinitat sobre el Puig Rom, en el extremo opuesto de la actual Rosas, se encuentra vecino a un castrum visigodo, presidiendo ambos por igual, en distintas épocas, el fondeadero situado a sus pies, actual puerto de Rosas. Se trata de una zona rocosa, desgracidamente muy urbanizada, pero que debe ser tenida muy en cuenta para el tema que nos ocupa.

Frente a la escasez de evidencias sobre la colina de Sta. María, las excavaciones en la Ciudadela de Rosas en los años 70 y 80 documentaron una amplia superposición de estructuras al otro lado de la riera (Rec Fondo) que limitaba por el norte la "acrópolis". Los restos más modernos dentro de la época antigua corresponden a una factoría de salazones tardorromana (Nieto 1993) superpuesta a un barrio residencial conocido como "el barrio helenístico", con calles alineadas en retícula ortogonal, que definen una parcelación homogénea y regular de casas. En estas casas vivían los ceramistas y comerciantes que produjeron a lo largo del siglo III a.C. la famosa vajilla de barniz negro del taller de las tres palmetas radiales, comercializada desde el Languedoc a Cartagena (Sanmartí 1978).

El estudio arquitectónico y urbanístico de todo este conjunto realizado por D. Vivó (1996), incluyendo una propuesta de restitución de las casas, prueba que se trató de un barrio ortogonal construido de nueva planta como una expansión o complemento del yacimiento original. Las calles de esta nueva plateia miden $4 \mathrm{~m}$. de anchura y las manzanas aprox. $20 \mathrm{~m}$. La parcelación de las manzanas ha podido también ser propuesta con precisión pero plantea diferencias en cada una de las dos alineaciones de manzanas documentadas: una en lotes de 6 y otra en lotes de 4 parcelas, utilizando siempre un mismo pie de 0,335 m. Esta diferente "lotificación" de las parcelas puede ser debida, considera Vivó (1996, 111) a un condicionante topográfico. Es decir que la zona excavada coincida con uno de los límites laterales del asentamiento. La restitución de una de las casas de mayor tamaño (A-II-3) muestra de forma convincente una magnífica casa de pastas del más puro estilo helénico.

D. Vivó señalaría igualmente el paralelo de esta ordenación urbanística con la planificación rigurosamente ortogonal del baluarte massaliota de Olbia (fundado c. 330 a.C.) o la documentada a orillas del Ródano en el emporion fluvial de Theliné / Arelate (Arles), en el barrio excavado en el Jardin d'Hiver, construido en los inicios del s. V. aC. y urbanizado de forma ortogonal en el siglo IV a.C. (Phase 3: 375-300 a.C.; Arcelin 1990; Arcelin 1995). Pero con posterioridad a su trabajo ha sido publicado un nuevo y magnífico ejemplo hispano de urbanística ortogonal de tipo griego que introduce nuevos matices en esta cuestión.

A principios de los años 90, una excavación de urgencia junto al puerto de Sta. Pola (Alicante) permitió documentar de forma amplia el magnífico poblado de La Picola: un recinto portuario con murallas, calles paralelas y parcelación normalizada, plenamente concebidas de forma ortogonal como un baluarte creado ex novo de tipo y modulación helénicos (Badie et alii 2000). Sin embargo, la facies cerámica imperante, plenamente ibérica, y la lógica arqueológica regional han obligado a P. Moret y P. Rouillard (2000, 254-265) a matizar con inteligencia una interpretación que inicialmente hubiera podido conducir directamente hacia un bastión militar como el ejemplo de Olbia. La distancia de apenas $12 \mathrm{kms}$. que separan La Picola del gran asentamiento ibérico de La Alcudia de Elche (la romana Ilici) les hace interpretar el asentamiento estrictamente como un pequeño emporion ocupado por una comunidad mixta de comerciantes marítimos e iberos, o bien de iberos comerciantes en un asentamiento diseñado por un arquitecto griego o de formación griega. Pero siempre definiendo el lugar como un enclave "ibérico" dependiente de la ciuitas principal de La Alcudia.

Para nosotros, tanto La Picola como el nuevo barrio de Rhode responden a las mismas funciones económicas que cumplía el enclave portuario de jonios en Gravisca respecto a la etrusca Tarquinia un siglo atrás. Pero algo importante había cambiado. Donde diversos altares, las estatuas de madera de diferentes divinidades y multitud de ofrendas apiladas bastaban para asegurar la neutralidad y el respeto en época arcaica, la "modernidad" de los siglos V y IV a.C. prefería construir en las costas centros de almacenaje fuertemente fortificados.

Griegos y púnicos se masacraron mutua $\mathrm{y}$ repetidamente en Sicilia a fines del siglo V a.C., y cuando las tropas de Dionisio de Siracusa saquearon en el 384 a.C. el santuario de Ilizia / Leucotea en Pyrgi, el puerto comercial de la etrusca Caere, con sus grandes templos del siglo VI a.C., eran plenamente conscientes de lo que estaban haciendo. Si trasladamos esta situación a las costas occidentales hemos de recordar que fueron precisamente los foceos los que introdujeron en ellas la práctica habitual de la piratería ("actividad gloriosa" la consideraban, nos recuer- 


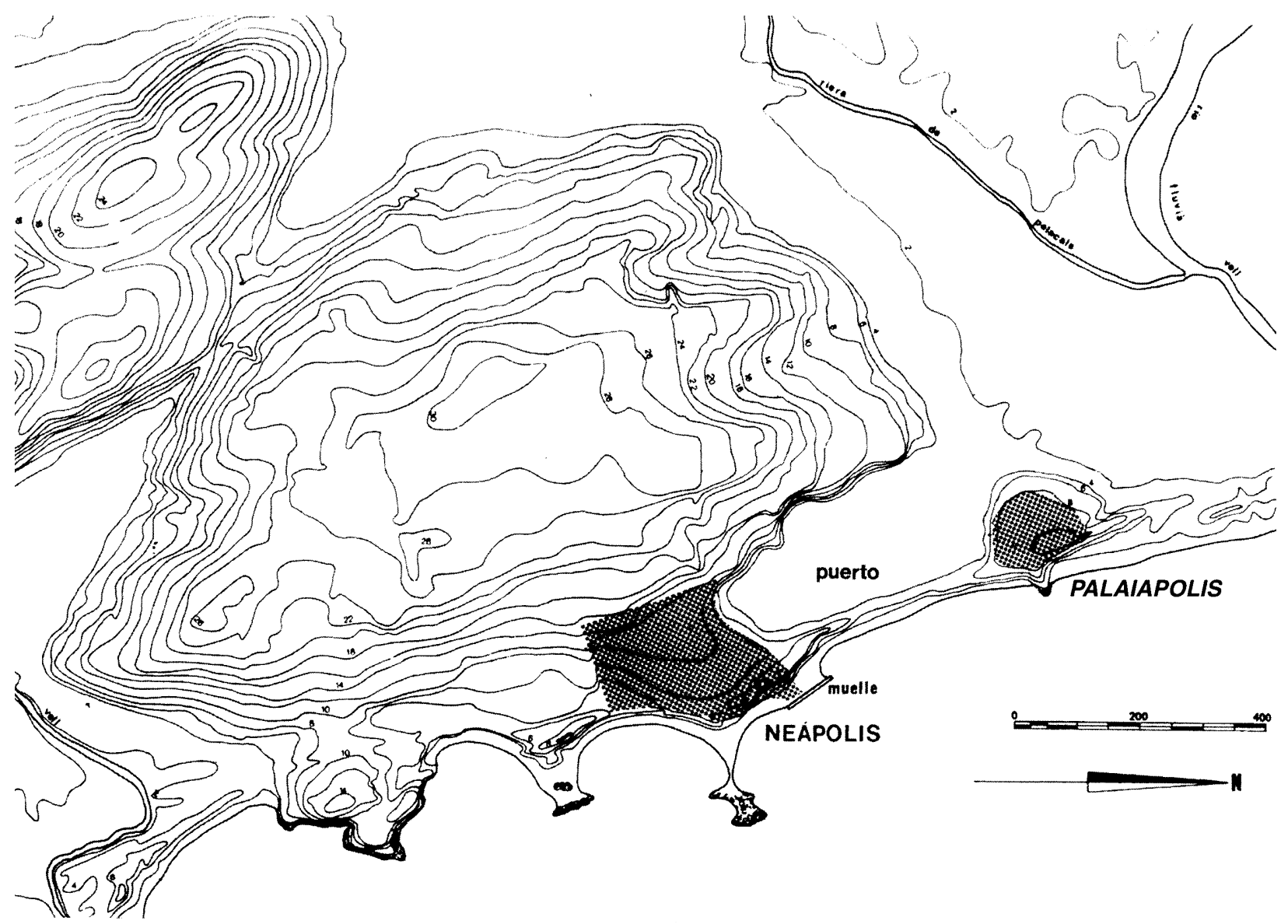

Fig. 7.- Emporion. Planta topográfica con la posición de la ciudad helenística (de Ruiz de Arbulo 1998 b).

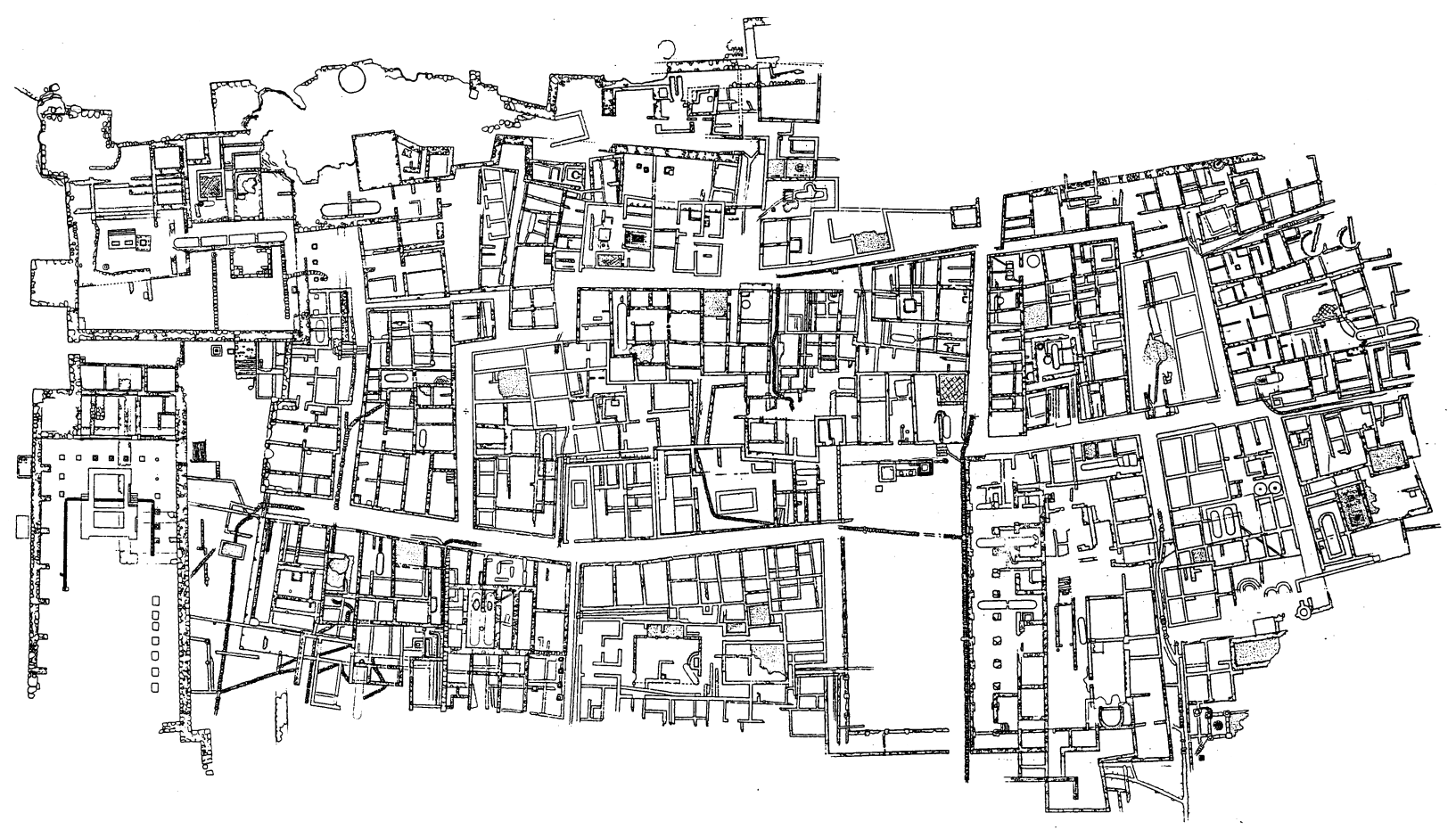

Fig. 8.- Planta de la Neápolis de Emporion (de Mar y Ruiz de Arbulo 1993). 

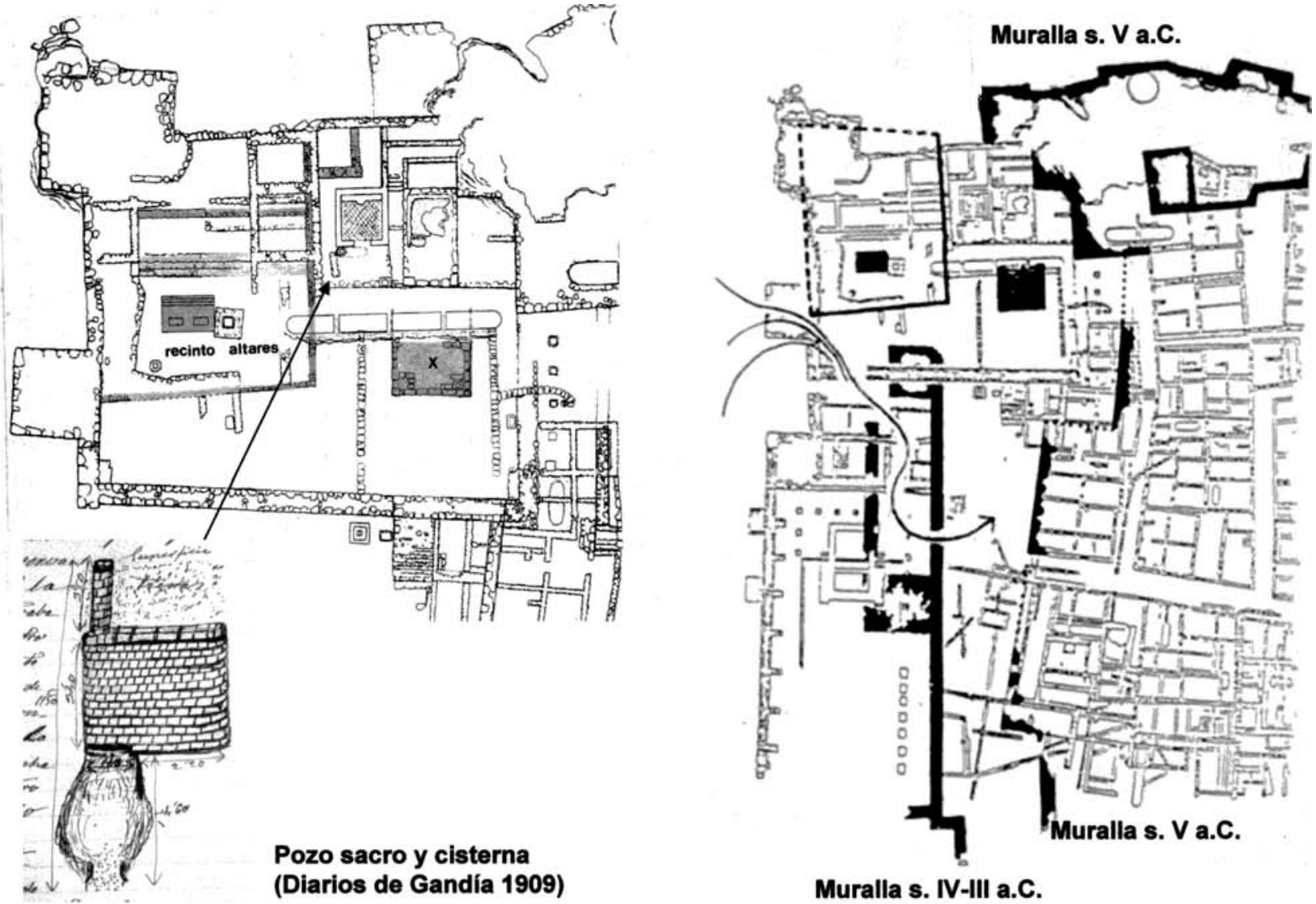

Muralla s. IV-III a.C.

Fig. 9.- Neápolis de Emporion. Santuario suburbano y evolución de las murallas en los siglos V-IV a.C.

da Pompeyo Trogo a través de Justino, Epit., 43, $3,5)$, contra el tráfico marítimo de etruscos y púnicos en el siglo VI a.C., justificando la batalla de Alalia en el 525 a.C. Un siglo más tarde, la piratería y el corso eran ya amenazas permanentes a lo largo de todas las costas y los "mecanismos de contacto" entre sociedades desarrolladas provistas ya de escritura habían evolucionado lo suficiente como para justificar la presencia de puertos fortificados, donde un contrato ante testigos escrito sobre plomo, era un complemento ineludible al simple apretón de manos ante un altar.

La barca comprada a medias en el puerto de Emporion por un tal [Ky]pr[ios] y un agente enviado por un comerciante jonio establecido en el oppidum de Pech Mahó, de nombre Herón de Ios (según Chadwick) o directamente Heronoiyos como prefiere De Hoz, a quien iba dirigido el documento, resulta un magnífico ejemplo de este nuevo mundo de los negocios marítimos internacionales en pleno siglo V a.C. (Lejeune, Pouilloux, Solier 1988; Santiago 1989; IGAI 7; De Hoz 1999).

\section{El paralelo de la Ostia arcaica y MEDIO-REPUBLICANA.}

El segundo tratado entre Roma y Cartago transmitido por Polibio (III, 24) que ha vuelto a revisar con gran agudeza P. Moret (2002) en relación a la ubicación no peninsular de Mastia, acredita en el año 348 a.C. la regulación de las áreas de influencia, la actividad colonizadora pero sobre todo las relaciones comerciales marítimas entre una gran potencia como Cartago y un poder regional emergente como era Roma, en un momento de gran intensidad de la actividad pirática. Moret recuerda la cita de Livio (7, 25, 46 ), relativa a los piratas etruscos y griegos activos en la costa lacial en el 349 a.C. contra los que nada pudo hacer Roma por carecer de naves suficientes.

Y esta situación en la costa del Lacio durante el siglo IV a.C. nos ofrece un paralelo ilustre para entender la problemática coetánea de Rhode que estamos intentando entender. En el siglo II d.C. una inscripción marmórea ostiense (CIL XIV, 4338; aparecida reaprovechada en una cloaca tardía en la vía dei molini) recordaba el 
carácter excepcional de Ostia como la primera colonia romana fundada en la mítica época regia por Anco Marcio, el cuarto rey de Roma: Anco / Marcio / Regi / Quarto a Romulo / qui ab urbe condita / primum coloniam / deduxit. El epígrafe y su estatua acreditarían una tradición histórica que ya describieron el poeta Ennio (a fines del III a.C.) y el historiador Livio (I, 33, 9) en relación con el aprovechamiento arcaico de las salinas litorales junto a la desembocadura del Tíber. Ahora bien, siendo Ostia una ciudad intensamente excavada, no existe ninguna evidencia arqueológica conocida que sea anterior al castrum amurallado de planta ortogonal perfectamente delimitado en el entorno del foro de la colonia sin que las fuentes antiguas mencionen su construcción. Un castrum construido en los inicios del siglo IV a.C. según la datación estratigráfica (cf. Zevi y Claridge 1996).

Esta paradoja ostiense resulta ahora bien explícita para resolver la cuestión de los orígenes de Rhode. También en Ostia se ha debatido la veracidad, deformación o mera invención de las menciones históricas, pero las líneas actuales de la investigación consideran más probable reconocer la existencia de una Ostia arcaica situable a cierta distancia al este de la colonia, aguas arriba del Tíber, en sectores todavía no explorados. En segundo lugar, el castrum ostiense refleja un excepcional ejemplo de la fortificación de las costas en el siglo IV a.C. (en este caso con una instalacion estimada de unos trescientos ciudadanos romanos como colonos militares), como elemento de vigilancia de una ruta fluvial esencial para la vida de Roma: una ensenada abierta en la desembocadura del río en la que debían detenerse los cargueros redondos de mayor tamaño para trasladar su carga a barcas de ribera o carros. Pero ante todo el castrum ositiense fue un recinto militar, desde el 267 a.C. sede de uno de los nuevos quaestores classici, encargados de organizar la flota romana en los años inmediatamente precedentes a la primera guerra púnica.

Por todo ello creemos que Rhode tuvo necesariamente que remontar su historia hasta el arcaismo (o hasta el mismo orientalizante si aceptásemos literalmente la tradición rodia), con su puerto ocupado simbólicamente desde el siglo VI a.C. por un primer Artemision. El asentamiento fue complementado en el siglo IV a.C. con un "baluarte" que debemos considerar la plasmación urbanística (y segura fortificación) de una nueva polis formada junto al principal puerto del golfo. Pero no se trató necesariamente de un epiteichisma massaliota, sino de una nueva ciudad que basó su independencia en la bonanza económica generada por el comercio con los iberos y

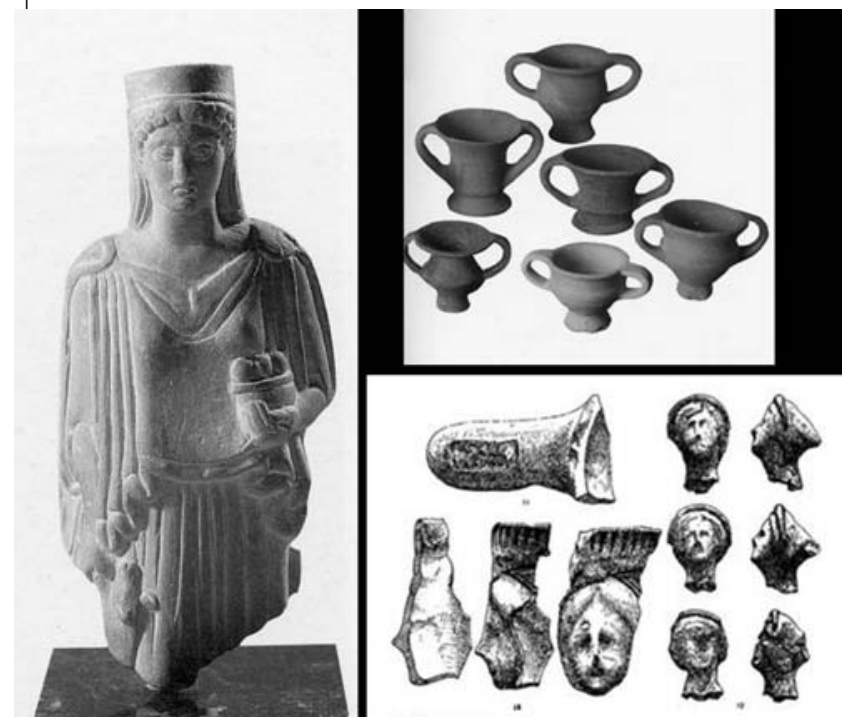

Fig. 10.- Emporion. Terracota con ofrenda de cochinillo. Vasitos votivos del templo suburbano del s. III a.C. (de Marcet y Sanmartí 1989) y ajuar de la tumba de incineración Las Corts 104 (de M. Almagro, Las necropolis de Ampurias, vol. 1, Barcelona, 1953).

que debió erigirse en símbolo de la seguridad de su puerto y de sus almacenes. Lo primero que comprobarían los nuevos comerciantes marítimos del siglo IV a.C. frente a la actividad perenne y periódica de la piratería sería la presencia de unas buenas murallas.

\section{RHODE Y LAS PRODUCCIÓN ARTESANAL DE PROTOMAI.}

Junto a las producciones de vajilla cerámica de barniz negro que ya hemos mencionado, los talleres artesanos del barrio helenístico de Rhode producían protomai del más puro estilo helénico como prueba el hallazgo de uno de los moldes con pasta massaliota (Martin 1978). Las protomai eran, como sabemos, máscaras de terracota $(\mathrm{y}$ de ningún otro material), hechas a molde, que reproducían únicamente la mitad anterior de la cara y hombros de figuras femeninas. En muchas ocasiones presentan orificios para ser colgadas en muros. Eran piezas utilizadas ampliamente a partir del siglo VI a.C. como ofrendas votivas y los depósitos de algunos santuarios siciliotas en Selinunte o Gela las han proporcionado literalmente a millares (Croissant 1983; Uhlenbrock 1988). Pero en Olinto o Morgantina estas figuras están también presentes en las casas presidiendo los cultos domésticos y como ajuares funerarios (Bell III 1981, 86-88).

Morfológica e iconográficamente son piezas que los griegos del siglo VI a.C. parecen tomar 
de la imaginería feno-púnica, discutiéndose una influencia chipriota arcaica o bien directamente una dependencia de los talleres de Cartago que las utilizó ampliamente como ajuares funerarios (Picard, C. 1966; Culican 1976; Ciasca 1988). De cualquier forma, su uso se divulgó rápidamente y fueron producidos por multitud de talleres. Además, como demuestra este molde de Rhode, los moldes podían viajar de una a otra ciudades acompañando a los artesanos.

En el mundo púnico estas imágenes femeninas se consideran representaciones de Tanit y en Sicilia son características de los cultos ctónicos de

m. de cota situada en las sierras interiores más allá de la paleolaguna de Castelló, a $12 \mathrm{kms}$ de la costa, en la confluencia de los ríos Llobregat y Orlina (Llinas et alii 1998; Martin y Puig 2001, 56 ss). Un hábitat implantado en la zona agrícola por excelencia que rodeaba la marisma litoral. Los materiales propios de ajuares de necrópolis aparecidos a fines del siglo XIX en el área del castillo de Perelada han sido complementados por las excavaciones arqueológicas realizadas en el núcleo urbano actual que han proporcionado evidencias de un oppidum amurallado a fines del siglo $\mathrm{V}$ a.C. pero con materiales que se remontan a los inicios del VI a.C. (copa jonia B2). A fines del s. IV a.C., el oppi-

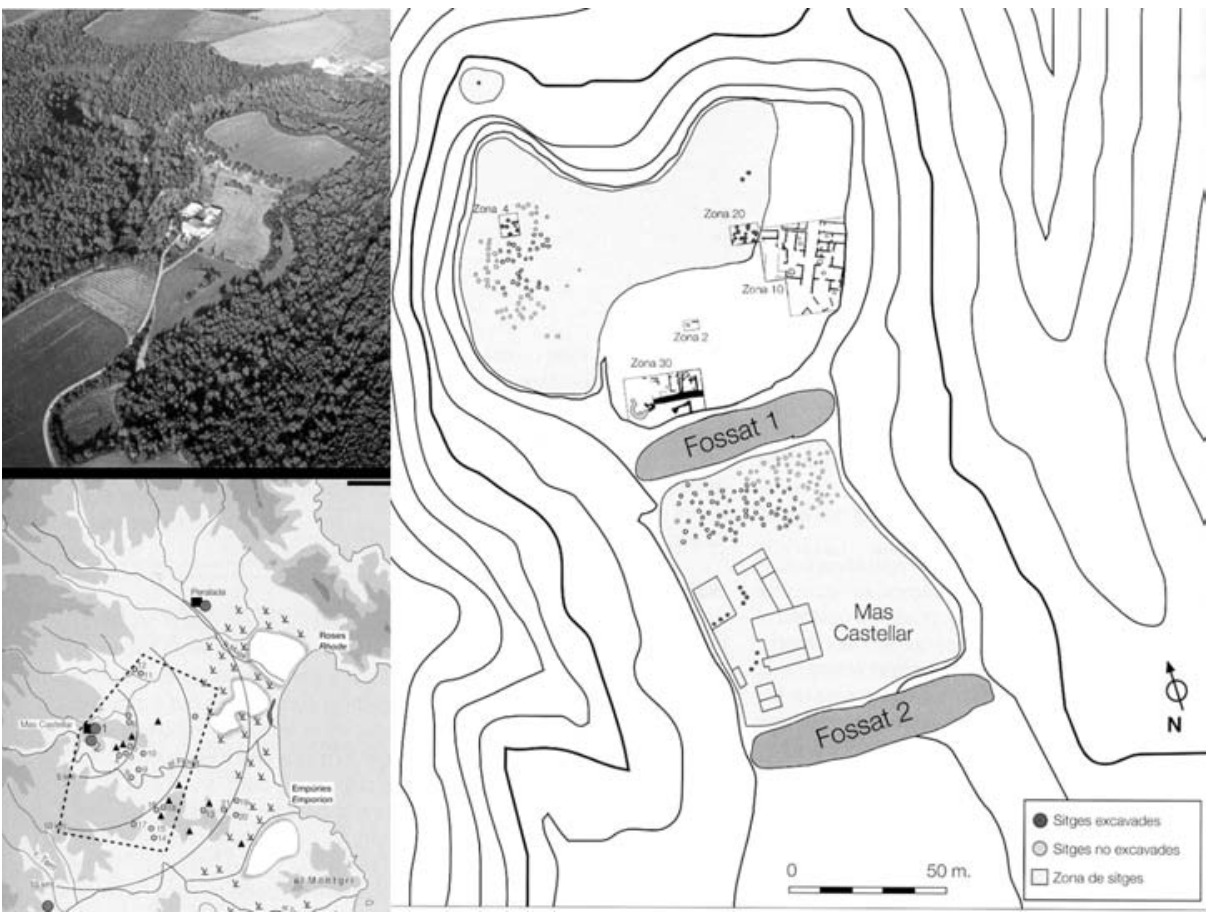

Fig. 11.- Mas Castellar de Pontós. Situación, foto aérea y planta del yacimiento (de Pons et alii 2002).

Deméter y Coré/Perséfone. El sincretismo entre los ámbitos de competencias respectivos se acredita en la fase de ocupación púnica del santuario de la Malóforos en Selinunte. En Rhode, la producción de coroplastia votiva debió estar destinada por lo tanto de una forma amplia a la imaginería de los cultos domésticos, a los ajuares funerarios y a las ofrendas votivas para los santuarios de la propia ciudad, encabezados por el Artemision, pero también para otros santuarios situados en el entorno de la misma.

\section{Perelada. OpPidum y CAMPo de Silos.}

Una de las novedades importantes de los años 90 ha sido la excavación del hábitat ibérico existente en Perelada, una pequeña elevación de 25 dum fue sustituido por un campo de silos cuya excavación ha mostrado repetidos niveles de colmatación a lo largo del siglo III a.C. Al mismo tiempo, otro campo de silos de dimensiones considerables ha sido detectado por prospección en los terrenos del actual club de golf, a unos 2 kms. de distancia.

La estratégica situación del oppidum de Perelada respecto a las dos vías terrestres que atravesaban los Pirineos por los pasos de Panisars y Banyuls ha sido ya remarcada con precisión (Martin y Puig 2001, fig. 1; Pons et alii 2001, 154). Unas rutas por las que durante toda la Edad Media circularon los rebaños ovinos de la transhumancia procedentes de las llanuras de Narbona y el Rosellón francés y que podemos quizás remontar hasta la Prehistoria.

Es importante destacar la transición que se produce en Perelada entre el primer oppidum y el vecino campo de silos por su similitud con la situación documentada en el vecino yacimiento de Mas Castellar de Pontós, 20 kms. más al sur. Volveremos más adelante sobre esta cuestión.

\section{EMPORION.}

La Emporion de fines del siglo IV a.C. era un puerto fuertemente fortificado con un doble asentamiento urbano ocupando la falda costera 
de una colina litoral situada entre las paleodesembocaduras de los ríos Fluvià y Ter. El puerto emporitano carecía totalmente de virtudes náuticas destacables. Era una ensenada abierta y de poco fondo, expuesta totalmente a los temporales de Norte y Levante. Pero una islita costera situada entre las paleodesembocaduras de dos ríos importantes significó sin duda una oportunidad única para los comerciantes marítimos. El arte de los hombres se ocupó pues de transformar y proteger artificialmente la ensenada y sus accesos.

Por el norte, la isla o tómbolo de S. Martí delimitaba una pequeña vaguada portuaria, hoy colmatada, al sur de la cual se situaba la denominada Neápolis, un amplio recinto amurallado desde el siglo $\mathrm{V}$ a.C. Un muelle realizado con grandes sillares ha sido considerado tradicionalmente el malecón de bocana del puerto emporitano situado en esta vaguada, pero las excavaciones submarinas que está dirigiendo J. Nieto en el tramo de costa lindante con la Neápolis, acreditan la existencia de un puerto "exterior" de gran entidad y una Neápolis extendida bajo las arenas de la actual línea de costa (Nieto y Raurich 1998; 2003).

Todavía es imposible poder definir con precisión la ubicación del Artemision emporitano. Su situación en la acrópolis massaliota sugeriría ubicarlo en la isla de S. Martí pero también es cierto que el originario templo efesio fue un gran santuario extraurbano a cierta distancia de la ciudad. Significativamente, las murallas meridionales de la Neápolis, construidas en el siglo V a.C., respetaron un gran santuario suburbano articulado en torno a un pozo sacro. En el siglo III a.C., formaban parte de este santuario un gran altar sobre podio de tipo helenístico y un recinto, delimitado por un muro de períbolos, provisto de bancos perimetrales y organizado en torno a un segundo altar monumental sobre un podio con dos aras en su coronación (Mar y Ruiz de Arbulo 1993, 171-182). A este impresionante conjunto, las nuevas excavaciones dirigidas por $\mathrm{E}$. Sanmartí en los años 80 añadieron el hallazgo de magníficas antefijas y fragmentos de acróteras en piedra, testimonios de un primer templo monumental en piedra de posición todavía no confirmada (Sanmartí, Castanyer, Tremoleda 1992; Cabrera y Sánchez 1999, catál. núms. 65 y 66).

Entre las ofrendas aquí encontradas queremos llamar la atención sobre unos pequeños crateriscoi votivos, publicados por Marcet y Sanmartí (1989) en un contexto de siglo III a.C.

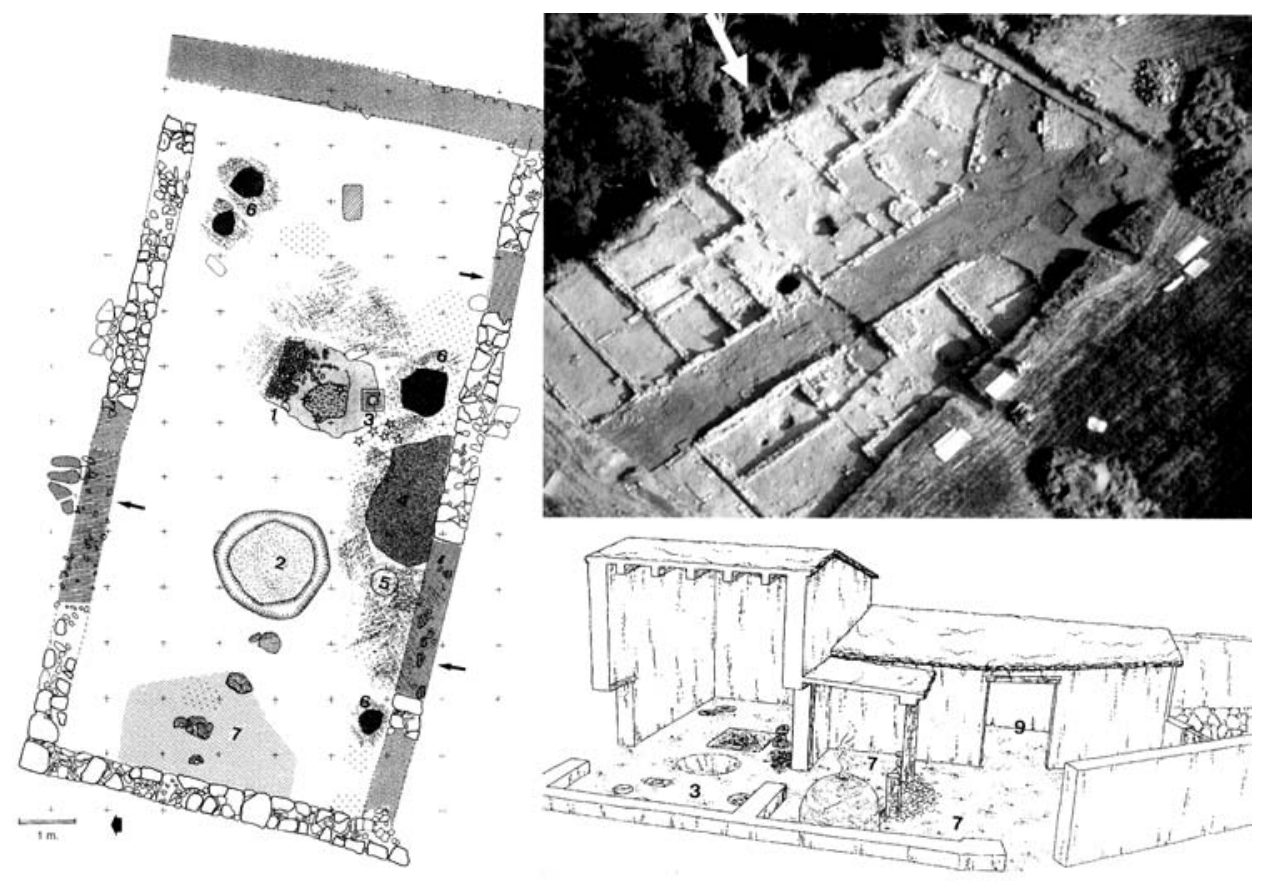

Fig. 12.- Mas Castellar de Pontós. Barrio perimetral del siglo III a.C. ("establecimiento rural"), planta con distribución de hallazgos en la estancia central de la casa 1, y restitución de la casa por D. Vivó (de Pons 1997 y Pons et alii 2002).

junto a pequeños exvotos anatómicos en terracota (Fig. 10). Uno de los vasitos, expuesto en una vitrina del MME contiene todavía pegados en su interior granos de cebada carbonizados. Una ofrenda singular y preciosa por cuanto estos vasitos son muy habituales en los hábitats ibéricos del interior y su presencia en este santuario nos plantea un primer elemento de contacto interétnico.

La dedicatoria de este santuario suburbano debe quedar condicionada por su transformación posterior. En los inicios del siglo II a.C. el santuario fue totalmente reformado y englobado dentro de la ciudad por la nueva muralla. El recinto ha sido siempre denominado santuario de Asklepios por el hallazgo en 1909 de la famosa 
estatua marmórea realizada en dos fragmentos y atribuida al semidios griego pero en la que hoy debemos reconocer, como más tarde comentaremos, una imagen tardo-helenística de Serapis. Si el Artemision hubiera estado siempre aquí, nunca habría podido mudar su sede, por ser la inamobilidad del lugar sagrado una premisa imprescindible en la definición de un santuario helénico. La "acrópolis" de la isla de S. Martí se convierte así en el lugar más posible para la ubicación del templo arcaico, que desgraciadamente no ha dejado testimonios apreciables.

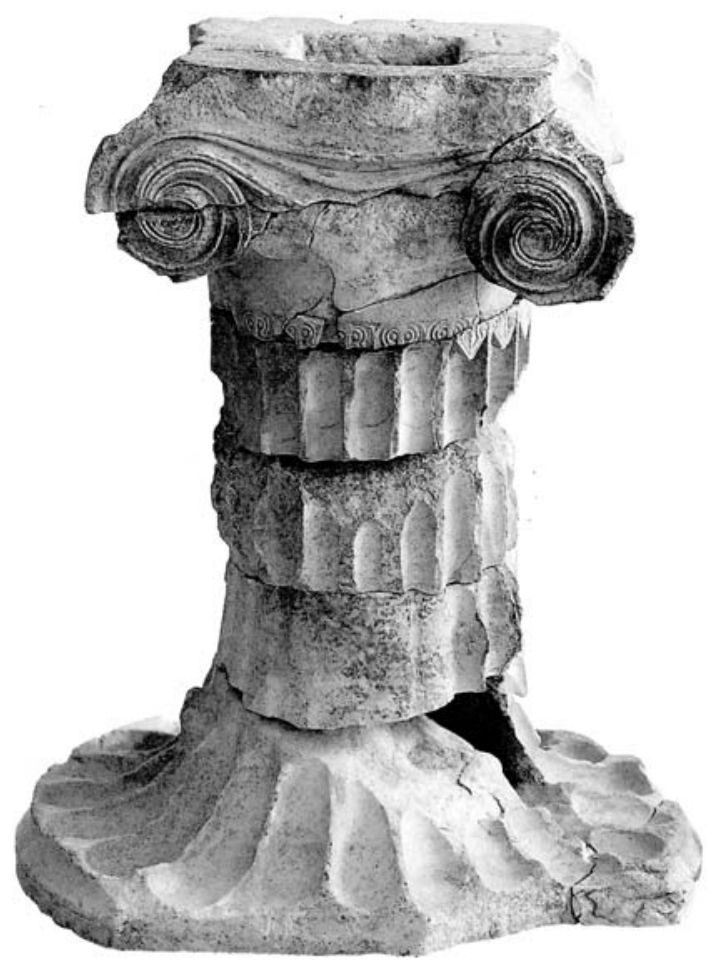

Fig. 13.- Mas Castellar de Pontós. Ara, pedestal o soporte helenístico en mármol pentélico aparecido en la sala central de la casa 1 (foto R. Manent, Enciclopèdia Catalana).

En este santuario suburbano, la asociación de un pozo, un primer templo de piedra, un altar monumental y un nuevo períbolos con banco perimetral presidido por un altar de doble ara, nos conduce fácilmente hacia los cultos agrícolas "perimetrales" característicos de la Sicilia griega y púnica por ejemplo en Gela o Selinunte, siempre presididos por las distintas variantes del ciclo de Deméter y Koré (cf. Polignac 1990). A este respecto, no podemos sino recordar de nuevo la presencia en Emporion de una figurita oferente de terracota de molde siciliota, una severa peplophoros tocada con gorro y velo nupcial llevando en su brazo derecho un lechoncillo, mientras con el izquierdo sostiene un cesto de pasteles (Blech 1994, C 13 , 95-96; Ruiz de Arbulo 2000, 37-39). Una imagen que nos remite directamente a las thesmoforia, las fiestas anuales reservadas a las matronas griegas, celebradas siempre en santuarios fuera de la ciudad, y que en el entorno de Gela han sido considerados un mecanismo de contacto entre mujeres griegas e indígenas. $\mathrm{Si}$ añadimos a esta pieza las cabecitas de Tanagras aparecidas en la amplia necrópolis tardo-republicana de Las Corts y los mal llamados pebeteros con cabeza femenina (cf. Ruiz de Arbulo 1994) observamos la abundacia de elementos emporitanos relacionables con el ciclo agrario de las diosas Deméter y Koré.

Los santuarios pasaron a convertirse así en los señalizadores del espacio urbanizado de los griegos como había recordado ampliamente F. De Polignac (1984) estudiando el arcaismo griego: los cultos nacionales originarios permanecen ahora en la acrópolis sacra y en los altares del bouleuterion y el pritaneon, los cultos periurbanos, curativos, oraculares o de carácter agrícola, rodean la polis como nuevos puntos de contacto y festividad colectiva, mientras que las imágenes de los dioses y los héroes sacralizan distintos puntos del territorio (fuentes, pasos, peñascos) como marcas de dominio, frontera o contacto con grupos foráneos.

En el siglo IV a.C. griegos e iberos coexistían en la polis emporitana como prueban no tan solo los materiales cerámicos de las estratigrafías, sino de forma aún más precisa los grafitos ibéricos sobre copas de vino áticas (Sanmartí-Grego 1993, 21). La famosa carta sobre plomo encontrada en la Neápolis en 1985 fue redactada $c .500$ a.C. por un armador jonio con sus instrucciones a un agente suyo en Emporion para desarrollar una operacion comercial en la que interviene un tal Basped en las cercanías de un lugar denominado Saiganta, con intervención de barcas de ribera y operaciones de remolque (IGAI 1; Santiago 1994). Una nueva carta sobre plomo, aparecida también en la Neápolis en 1988, está redactada totalmente en ibérico y tiene como destinatario a un tal Katulatien, aunque con una cronología muy posterior, ya a fines del s. III a.C. (Sanmartí-Grego 1993, 22). En esta cuestión, los estudios linguísticos de J. De Hoz (1993; 1994), han remarcado la importancia de diferenciar los distintos grupos étnicos ibéricos, autores de hasta tres escrituras diferentes, por la posibilidad de ver entre los participantes de estos negocios marítimos del siglo $\mathrm{V}$ a.C. no tan solo a griegos e iberos locales sino también iberos foráneos, por ejemplo del área contestana, participando por igual en los mismos. 


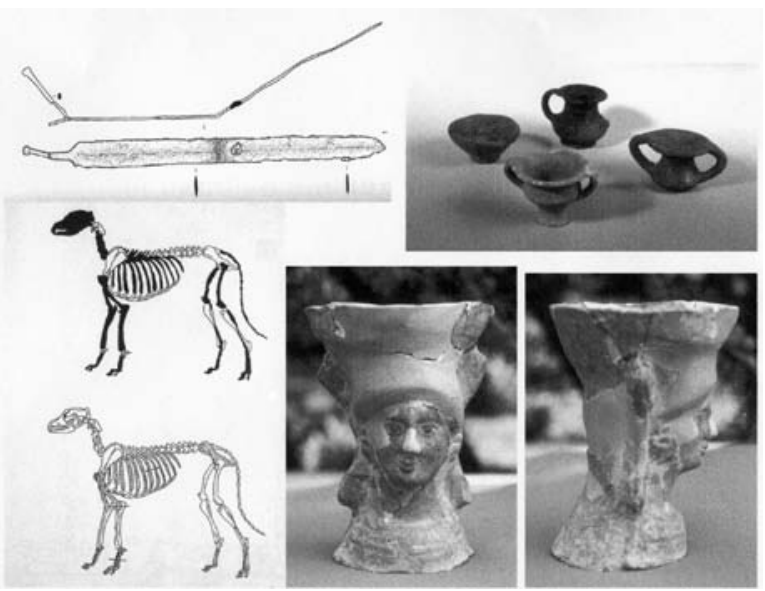

Fig. 14.- Mas Castellar de Pontós. Sacrificios de perros, vasitos votivos y espada enclavada del entorno de la sala central de la casa 1 . Terracota con cabeza femenina del silo 28 (de Pons et alii 2002).

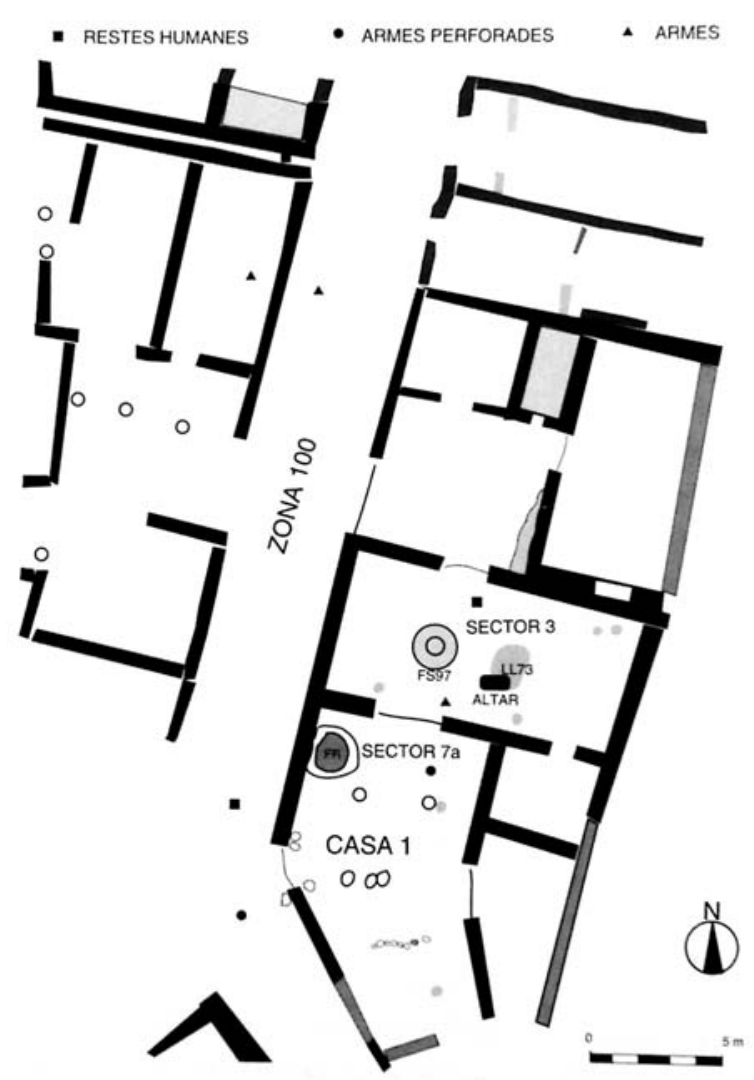

Fig. 15.- Mas Castellar de Pontós. Situación de los hallazgos de cráneos y espadas enclavadas en el barrio perimetral de siglo III a.C. (de Rovira 1998).
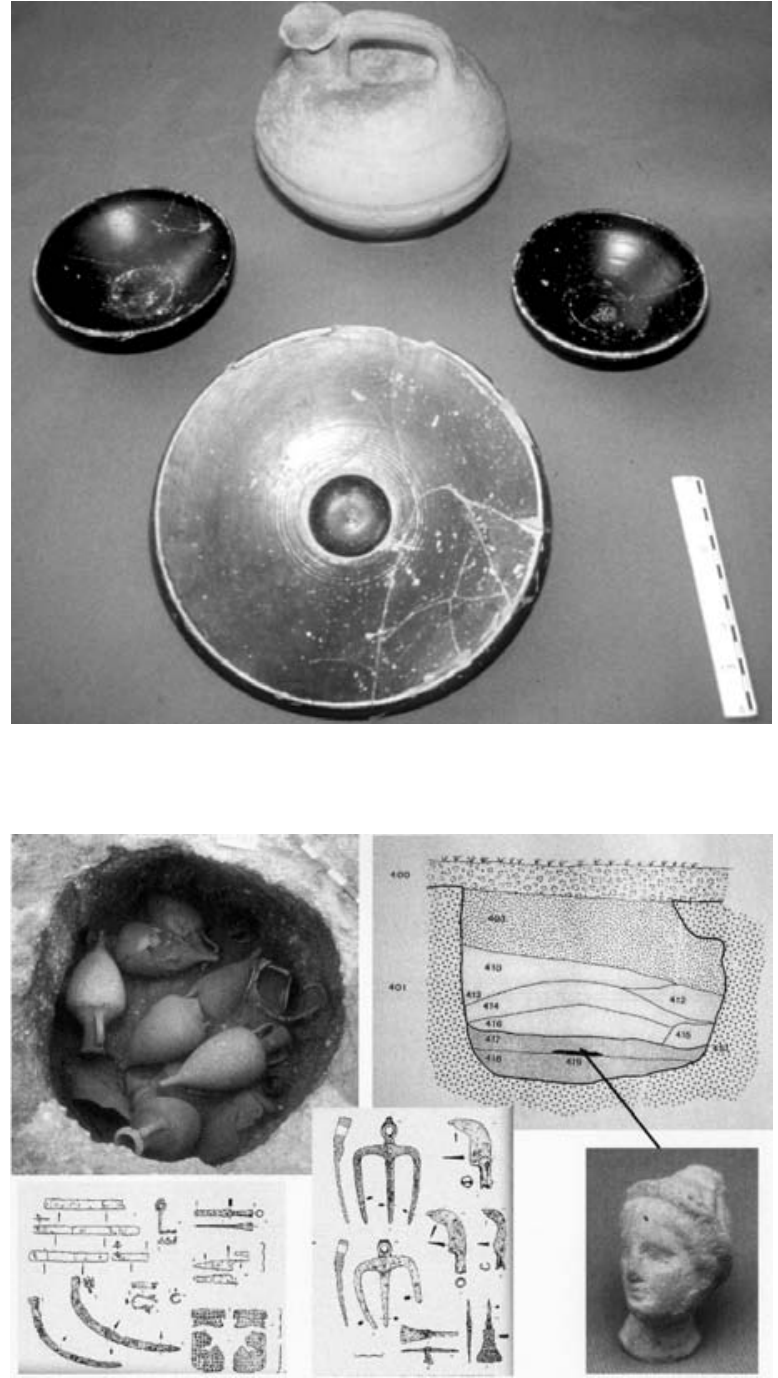

Fig. 16. a y b. - Mas Castellar de Pontós. Depósito votivo del silo 101 (de Pons et alii 2002). Cabecita de Tanagra ofrendada junto al altar/hogar, útiles agrícolas de hierro, vista del conjunto anfórico, materiales de barniz negro y ascos en cerámica oxidada emporitana (de Pons et alii 2002).

\section{Mas Castellar de Pontòs.}

Bellum se ipsum allet, "la guerra se alimentará a sí misma”. En el año 195 a.C., el consul Catón fue enviado por Roma para sofocar la gran sublevación de los iberos contra la nueva administración provincial implantada en el 197 a.C. Catón concentró su flota en el ya citado Afrodision o Puerto del Pirineo, oculto tras el cabo de Creus, para efectuar un primer desembarco de guerra en Rhode, expulsando a la guarnición de hispanos y acto seguido dirigirse a Emporion. Dado que el desembarco en Rhode pudo ser contemplado sin problemas desde Emporion, al otro lado del golfo, podemos imaginarnos fácilmente el espectáculo 
de un mar repleto de barcos romanos y que los emporitanos recibieran al cónsul con toda cordialidad, mientras los iberos rebeldes sencillamente se esfumaron. Instalado el campamento, el cónsul pronunciaría esas famosas palabras al despedir a los publicanos suministradores que acompañaban a su ejército, contribuyendo con ello a labrarse una fama proverbial de tacaño feroz, aunque justo y ecuánime (Martínez Gázquez 1974). Pero no se trató de un farol, impropio en un estratega, ya que Livio $(34,9,10$ 13) nos explica brevemente la razón del desplante:

"Se daba la circunstancia de que era aquella la época del año en que los hispanos tenían el trigo en las eras; y así, habiendo prohibido a los suministradores que acaparasen trigo y habiéndoles reexpedido a Roma dijo: "La guerra se alimentará a sí misma". Habiendo salido de Ampurias incendia y saquea el campo enemigo y todo lo cubre de huidas y terror".

A fines de los años 70, A. Martin llamó la atención sobre diversos yacimientos ibéricos situados en las sierras que rodeaban interiormente el golfo de Rosas caracterizados, casi exclusivamente, por agrupaciones de silos cavados en la roca natural rellenados en diferentes momentos con tierras de vertedero (Martin 1977; 1979). Uno de estos yacimientos fue investigado con mayor detalle, demostrando mediante prospección poseer una concentración de silos muy elevada. Se trataba del Mas Castellar, una masía del termino de Pontós cuyos propietarios recogían continuamente en cada labranza materiales ibéricos y áticos de gran calidad. El Mas Castellar está enclavado sobre una pequeña meseta cortada por la riera Alguema, un pequeño afluente del río Manol, a su vez tributario de la Muga, pero que en la Antigüedad desagüaba en la gran laguna de S. Pere Pescador. Unos pocos kms. al sur del yacimiento, la región es atravesada por el cauce del Fluvià, por lo cual la ubicación del lugar resulta equidistante de Emporion y Rhode y de comunicación óptima por ambos cauces fluviales.

Entre 1990 y 1998, Mas Castellar de Pontós ha sido investigado de forma continuada por un amplio equipo dirigido de forma tenaz y brillante por E. Pons, con trabajos divulgados de forma casi inmediata mediante variados artículos y ponencias culminados con una espectacular monografía (Pons et alii, 2002). Una síntesis que cubre ampliamente todas las cuestiones susceptibles de estudio en una excavación arqueológica. Resumiendo sus conclusiones, sobre la citada meseta se desarrolló en el siglo $\mathrm{V}$ a.C. un poblado fortificado de barrera, con acceso protegido por rampas y bastiones. La muralla fue destruida $c .400$ a.C. para dejar paso a un hábitat diferenciado, caracterizado casi exclusivamente por una enorme aglomeración de silos, dispuestos en dos recintos consecutivos separados por grandes fosas y un pequeño hábitat doméstico instalado en la parte superior de la colina datable en el siglo III a.C. con casas alinadas a los lados de una calle perimetral que ha sido denominado el "establecimiento rural". La abundancia de materiales de todo tipo dispersos por las habitaciones de este barrio edificado, piezas metálicas abandonadas sobre los pavimentos, una pieza suntuaria rota de forma premeditada y una ocupación que se interrumpe de pronto prueban que el yacimiento fue atacado por sorpresa en los inicios del siglo II a.C. Después de ese momento, tan solo se documentan indicios de ocupaciones puntuales de carácter temporal que van extinguiéndose a lo largo del siglo II a.C. (cf. Pons et alii 2002, 591-593).

Como decimos, toda la terraza superior de Pontós estaba ocupada por un campo de silos con excepción de una calle perimetral con viviendas en ambos lados. Se trata de casas complejas, con varias habitaciones organizadas en torno a patios dotados de pórtico distribuidor, con planta superior, en todo análogas a las casas urbanas mediterráneas de tipo griego y púnico de los siglos IV y III a.C. Almacenes, prensas, hornos de pan, pequeños hornos metalúrgicos y depósitos se alternan con salas de aparato $\mathrm{y}$, al menos en una de las casas, una gran sala destinada al culto doméstico o comunitario (Pons et alii 2002, 97-164).

Esta casa 1, organizada en torno a un patio provisto de un pórtico a modo de pastas griego, disponía de una gran sala de aparato repleta de evidencias cultuales. La sala estaba organizada en torno a un gran hogar rectangular central presidido por una pieza de origen griego, de altísima calidad, realizada en mármol blanco pentélico. Se trata de una basa circular estriada de ancha base moldurada, culminada en un capitel jónico finamente trabajado que fue encontrada in situ pero ferozmente troceada de forma intencionada. Hemos estudiado esta pieza sin haber sido capaces de definir su uso con total seguridad. Pudo tratarse de un altar griego o del pedestal para una pequeña escultura, aunque ciertamente su forma corresponde mejor a los pies para mesas y pilas (trapeza y perirranteria) ampliamente documentados en Delos y en los monopodia de Pompeya (Pons, Ruiz de Arbulo y Vivó 1998).

Pero ante los restos del gran hogar delantero, la hipótesis del ara pierde cualquier significado. Si hubiera sido el pedestal para una pequeña 

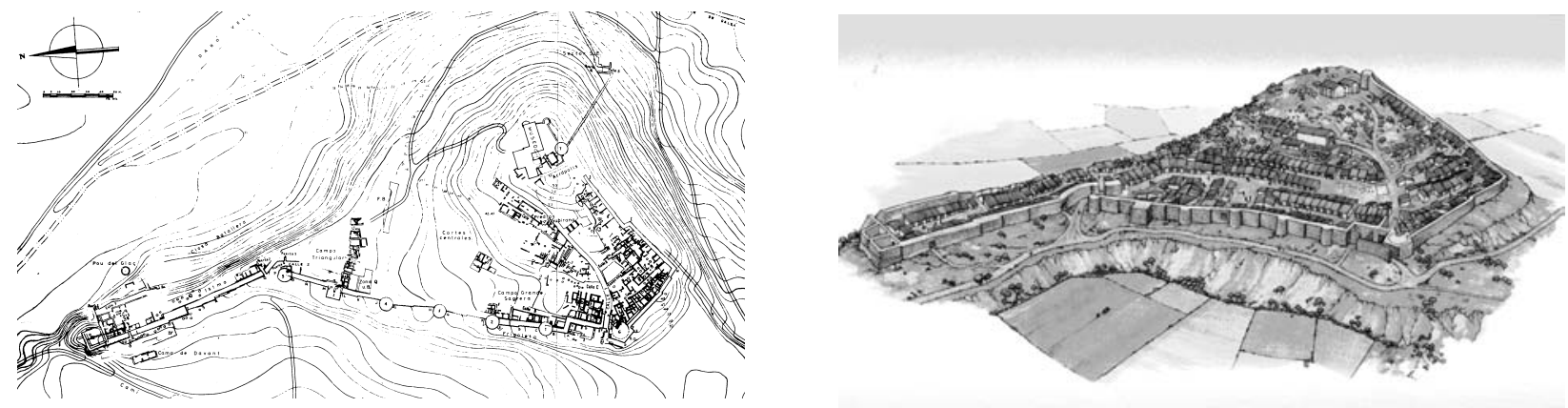

Fig. 17 a y b.- Ullastret. Planta de las excavaciones en el Puig de S. Andreu en los años 70 (de M. Oliva, Excav. arqueol. en el yac. Prerromano deUllastret, NAH, 1976, 733ss). Restitución del oppidum de Ullastret. (Ilustración de F. Riart y O. García en F. Gracia et alii, El llibre del ibers, Tarragona 2000).

imagen de culto, la parte superior de la pieza hubiera debido tener un tratamiento diferente. Y si fue, como parece por su tipología, el pie de una mesa sacra o de una pila hubieran debido aparecer necesariamente fragmentos de la pieza superior. Por todo ello hemos propuesto que se trató de una pieza cultual en sí misma, transformándose su uso inicial en un contexto griego para convertirse en un ídolo betílico de tradición semita y púnica. Una costumbre que sabemos de uso muy extendida en el mundo íbero meridional como emblema abstracto de la divinidad (Pons, Ruiz de Arbulo y Vivó 1998; v. ahora también Perea et alii 2003).

Nos llama la atención el hecho de que la pieza presente un peculiar alisamiento rectangular en su parte frontal inferior. No hay agujeros para clavos o pernos y por tanto no pudo tratarse de una placa insertada, de uso por otra parte sin precedentes que sepamos en piezas helenísticas de este tipo. De forma muy hipotética, podríamos quizás pensar en un tipo de ritual que consistiera en tocar el fuste estriado, o mejor frotar objetos (útiles, aperos, armas) contra el mismo. No queremos con ello decir que las estrías del fuste desaparecieran literalmente por los continuos roces, sino que estas estrías se rebajaron conscientemente para formar ese recuadro plano señalando el área que debía ser tocada. Un gesto de "transmisión por contacto" pluricultural perfectamente documentado. La visita a las reliquias de los mártires por los devotos cristianos de la Antigüedad Tardía o cualquier festividad, todavía hoy en día, ante la imagen de la Virgen en un gran santuario mariano, resultan a este respecto bien indicativas.

Junto al hogar central apareció una fosa $(2 \mathrm{~m}$. diám. por $47 \mathrm{cms}$ de prof.) que Pons $(2000,535)$ propone reconocer como un depósito de agua para la que hemos de imaginar un uso básicamente lustral. La sala disponía además de otros cinco hogares altares perimetrales más pequeños, que proporcionaron restos quemados de perros, también aparecidos en el interior del depósito central (ver para este rito Pons, Ruiz de Arbulo y Vivó 1998, 61-62). Además, la sala proporcionó molinos de mano, una lucerna Ricci D en barniz negro y cuatro vasitos votivos (6 más en los espacios anexos) del mismo tipo de los encontrados en el santuario suburbano emporitano (Fernández y Pons 2001, 378-380).

Además, la puerta de acceso al patio exterior desde la calle, el pórtico de acceso a la sala y también su interior debían estar "decoradas" con espadas largas envainadas clavadas en paredes y puertas (Rovira 1998; 2001, 363 y 540-541). En último lugar, la sala proporcionó un fragmento de cráneo humano con evidencias de consumo de alucinógenos (claviceps sp.) en uno de los molares y el mismo hongo ha sido detectado en el interior de uno de los vasitos votivos (JoanTreserres 2002, 550 y 555).

Uno de los silos de la terraza superior (SJ 101) proporcionó un magnífico conjunto votivo organizado "a la griega" como una ofrenda subterránea en bothros dedicada a las divinidades ctonias (Adroher, Pons y Ruiz de Arbulo 1993; Pons y Rovira 1997). Sobre un fuego / altar inferior a modo de eschara se quemaron olivas, bellotas y cereales y se ofrendó la cabecita de terracota de una Tanagra (en probable representación de la divinidad). Encima se depositó una amplia selección de útiles agrícolas en hierro en perfecto uso (almocafres, picoletas, podaderas, cuchillos, sierras, formón, rallador), junto a una llave de hierro y algunos elementos de bronce (torques, fíbula, bola perforada, arete de pendiente; v. ahora Rovira 2002), entremezclados junto a 9 ánforas grecoitálicas y 4 ánforas ibéricas (vaciadas en un banquete previo?) y una cuidada y simbólica serie de vasos cerámicos representativos de usos variados: cuencos y plato de pescado en barniz 
negro, ungüentario, ascos en cerámica ibérica, cálato de asas trenzadas en cerámica ibérica pintada y un mortero, todos conservados completos. En último lugar aparecieron también 22 piezas discoidales recortadas de piezas cerámicas. Los restos de fauna, muy poco abundantes (60 restos), corresponden a oveja / cabra, perro, cerdo, buey, asno y ave indet (Casellas 2002, 494).

La datación de este excepcional depósito votivo debe apoyarse en el perfil antiguo de las ánforas grecoitálicas (son todavía piezas pequeñas y anchas, con labios triangulares de tendencia horizontal, pero ya con pivotes macizos), y en tres piezas significativas de barniz negro: un cuenco Lamb. 17 del taller de Rosas, un plato de pescado Lamb. 23 y un cuenco Lamb. 27 en Camp. A. Un contexto para el que propusimos en su momento una datación c. 200 / 175 a.C., antes de la llegada masiva a las costas hispanas de las formas "industrializadas" de Campaniense A (cf. Ruiz de Arbulo 1993). Sin embargo, la presencia del cuenco de Rosas, fabricado en el siglo III a.C. según las cronologías propuestas por E. Sanmartí-Gregó (1978) confirmadas posteriormente por multitud de contextos, junto a piezas antiguas de la Camp. A; el estudio ya realizado de los epígrafes griegos y latinos (Garcia 2000) y el examen del resto de piezas presentes, permiten aceptar con precisión una fecha c. 200-190 a.C., siendo sintomática la presencia en las ánforas de sellos y grafitos latinos, testimonio de un comercio itálico que siguió desde el 218 a.C. los pasos de las tropas romanas en Hispania.

Algunos silos excavados en los años 70 proporcionaron contextos de nuevo relacionables con deposiciones votivas intencionadas. Resulta significativo a este respecto el relleno observado en el silo 28 conteniendo seis terracotas con cabeza femenina como las documentadas ampliamente en Emporion y Ullastret (Adroher, Pons y Ruiz de Arbulo 1993, 60-61; Ruiz de Arbulo 1994 b).

Otra de los elementos característicos de Pontós es la presencia de una gran cantidad de piezas discoidales en cerámica. Aparecen con escasez en los niveles antiguos del oppidum (35 ejemplares) y sin embargo en gran número en las casas del siglo III a.C. (2.198 ejemplares). El estudio sobre su dispersión muestra concentraciones significativas de decenas o cientos de estas piezas en diferentes habitaciones (Fernandez y Pons 2002 , 375-377, fig. 12.9). En su momento (Adroher, Pons y Ruiz de Arbulo 1993, 53-54), propusimos relacionarlas con pequeños telares móviles siguiendo una propuesta de Z. Castro (1979) pero también es posible que se utilizaran para un sistema de contabilidad, imprescindible en un yacimiento cuyo uso primordial fue el almacenamiento comunal.

A fines del siglo III a.C. coinciden en Mas Castellar de Pontós ritos agrarios de clara influencia helénica junto a ritos heroicos y oraculares de la más pura tradición celta y que comentaremos de nuevo más adelante. Y con ello todo parece tener un doble sentido. El ara o pedestal griego helenístico de primera calidad se transforma quizás en un ídolo betílico de lógica meridional y semita con poderes mágicos de uso incomprensible (o ridículo) para un griego. Las espadas y cráneos enclavados nos hablan de una sociedad guerrera y clánica pero junto a ellos el depósito votivo del silo 101 documenta de forma específica un ritual agrario ctonio del más puro estilo helénico en torno al altar / eschara de base, con una ofrenda de herramientas de labor en todo semejantes a las que sabemos ofrendadas a Artemis Agratera en las cercanías de Tarento en el siglo VI a.C. (cit. en Pons, Ruiz de Arbulo, Vivó 1998, 63).

Resulta significativa la ausencia en el depósito votivo del silo 101 de ánforas de aceite ebusitano y vino massaliota. A fines del siglo III a.C., el vino massaliota comenzaba a ser sustituido por los vinos suditálicos y magno-grecos, mientras que la ausencia de ánforas de aceite (y salazones) probaría que la lógica del conjunto anfórico ofrendado fueron sus contenidos alcohólicos. Aparentemente, un mercader acercó al yacimiento una buena cantidad de litros de buen vino que debieron ser consumidos en un banquete convivial junto a la probable cerveza envasada en las ánforas ibéricas. Y este consumo no se realizó en un symposion sino de una forma "bárbara" (¿̇ ya "moderna"?), sin el oportuno rebaje en una crátera del vino con agua, ni la obligada presencia de las copas, rotas y ofrendadas al finalizar el acto. Un banquete, que pudo quizás sellar la última gran venta efectuada en el yacimiento de parte de los cereales de la cosecha anual.

No existe en Emporion ni en Rhode ninguna pieza de calidad equiparable al ara de Pontós. El paralelo que siempre hemos citado de la pequeña ara jónica aparecida en el santuario suburbano emporitano es una pieza realizada en arenisca de calidad muy inferior (ver foto en Cabrera, Sánchez 2000, núm 71 -A. Castanyer-). Pero ésto resulta del todo lógico. Si buscamos las piezas corintias y áticas arcaicas de mayor calidad no debemos acudir a Corinto ni Atenas sino a las tumbas principescas etruscas que las recibieron.

La denominación de "establecimiento rural" (Pons et alii 2000, 590) dado por los excavadores 
a este conjunto, aunque aséptica y rigurosa, nos parece claramente insuficiente. El equipo de excavación ha estudiado de forma precisa que en los siglos IV y III a.C. Pontós fue ante todo un gran campo de silos, y como tal, un centro de almacenaje de grano de una escala no local sino claramente regional (Gonzalo et alii 1999; Pons et alii 2002, 591-594). Y la función de este almacenaje guarda una relación directa con la llegada al lugar de productos suntuarios de prestigio de origen griego, algunos de carácter religioso, procedentes de Emporion y Rhode. Ahora bien, debemos por ello preguntarnos como pudo desarrollarse este modelo económico de recogida, almacenamiento, venta y transporte (o viceversa).

\section{UN PARALELO ETNOGRÁFICO PARA LOS Campos de silos de Pontós y Perelada. LOS GRANEROS COLECTIVOS (O GRANEROS FORTIFICADOS) DEL MAGHREB.}

El estudio global sobre los silos ibéricos del noreste de Catalunya, entendidos como sistema de almacenamiento, fue objeto de la tesis doctoral del prof. J. Burch (1996 a; 1996 b). Un estudio estadístico del conjunto de los datos estratigráficos disponibles sobre 700 silos en 29 yacimientos distintos le permitió observar que los siglos II y I a.C. es el momento en que aparecen silos en mayor número de yacimientos (28 casos frente a solo 9 en el III a.C.), siendo también éste el momento con mayor número de obliteraciones estratigráficas.

Teniendo en cuenta estos datos, es sin embargo necesario diferenciar los tipos de yacimiento. En Ullastret, por ejemplo, podríamos justificar la gran presencia de silos por tratarse del centro urbano monumental que presidía un determinado territorio, residencia de las élites y de una parte importante de la población. En Sant Julià de Ramis, como veremos más adelante, el oppidum ocupa lo alto de la carena fortificada y el campo de silos se sitúa en una clara posición suburbana, al pie de la colina y junto al paso del río. Una situación que ningún táctico helenístico podría explicar desde el punto de vista del almacenamiento defensivo. En Pontós y en Perelada, por último, oppida y campos de silos parecen presentar cronologías complementarias, amortizándose los primeros para dejar paso a los segundos, acompañados en Pontós por una serie reducida de unidades residenciales de carácter singular.

Nuevos estudios de conjunto sobre la problemática de los campos de silos en toda Catalunya, su evaluación cronológica y funcional, han remarcado de nuevo la importancia singular de aquellos yacimientos donde el número de silos documentados supera con creces las necesidades de almacenamiento estimables para una población local, teniendo en cuenta los períodos de amortización de los silos y los lapsos cronológicos totales de ocupación. La conclusiones finales, coincidentes, remarcan ante todo el papel económico de estos lugares como centros de acumulación de excedentes cerealísticos destinados al comercio marítimo mediterráneo entre los siglos VI y III a.C. (Gracia 1995; Asensio, Frances, Pons 2002).

Un análisis semejante, realizado por $\mathrm{D}$. García (1987; 2000) para los hábitats de la Galia meridional, señala de forma rotunda la importancia de la cerealicultura para la tranformación de las sociedades de la Edad del Bronce en la nueva civilización de los oppida sudgálicos a partir del siglo VI a.C. Una transformación profundamente marcada, una vez más, por la emporía marítima de fenicios occidentales en un primer momento, más tarde sustituidos por factorías como Agatha (Agde) y otros mercados de redistribución costera destinados a una Massalia que al igual que Atenas siempre fue deficitaria en grano.

El caso de Pontós, excepcional por la abundante documentación disponible y al conocimiento del territorio gracias a los trabajos de prospección, ha podido ser identificado como una entidad de almacenaje cerealístico con carácter territorial y destinada a la exportación (Gonzalo, Lopez, Pons, Vargas 2000). Dispondría por tanto de un ámbito propio de dependencia, con un hábitat disperso que incluiría nuevos centros menores de almacenaje en silos y diferenciado funcional y quizás también "políticamente" de Perelada (al N), Ullastret (al SE) y S. Juliá de Ramis (al S).

En Pontós, la definición global del yacimiento debe tener en cuenta su fisionomía peculiar, su urbanismo de casas complejas únicamente perimetral, rodeando un gran campo de silos central y la presencia del nuevo gran campo de silos exterior. No estamos por supuesto ante un oppidum clásico, un simple recinto habitado y amurallado, pero tampoco ante una pequeña aldea o agrupación de casas simples para un grupo o clan de agricultores. La variedad de actividades económicas y la importancia simbólica de los ritos evidenciados debe apuntar en otra dirección de mayor peso económico y social.

En un momento todavía muy inicial de la reciente investigación, propusimos a E. Pons y A. Adroher que debíamos identificar el yacimiento como un santuario empórico, ligado a cultos agrícolas protagonizados por el ciclo de Deméter 
y Koré / Perséfone, en sincretismo con Tanit y las divinidades ibéricas equivalentes (Adroher, Pons, Ruiz de Arbulo 1993). Diez años después, y a partir de las nuevos datos evidenciados, nos reafirmamos de nuevo en la misma idea, que expre-
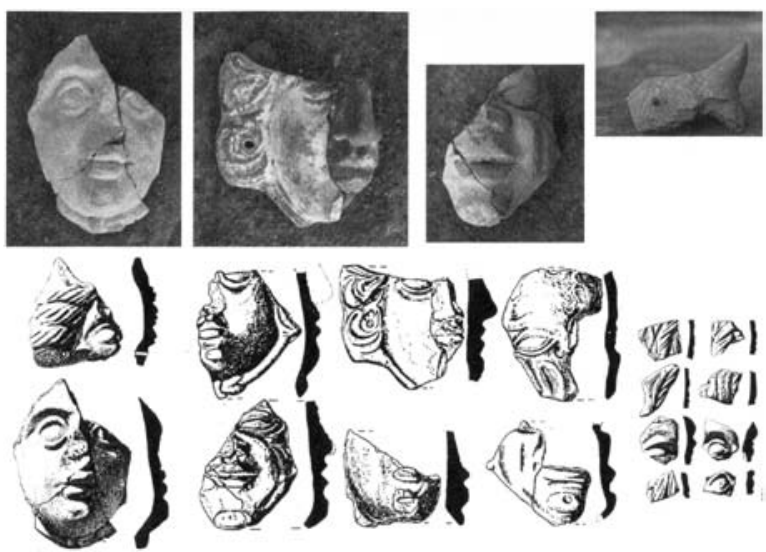

Fig. 18.- Máscaras de terracota aparecidas en la acrópolis de Ullastret (fotos autor; dibujos de M. Oliva, 1955 y 1959). Escalas aproximadas.

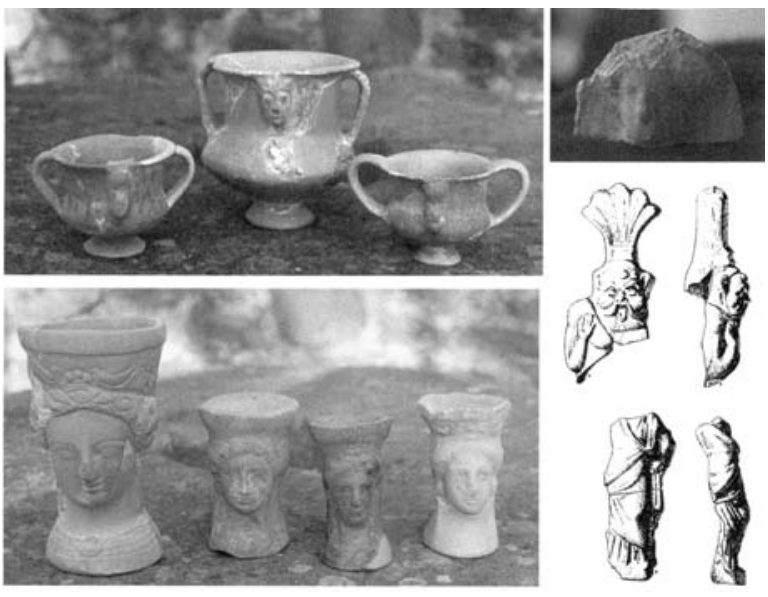

Fig. 19.- Ullastret. Vasos ibéricos con caras aplicadas, terracotas con cabeza femenina, tanagra helenística e imagen ebusitana de Bes (fotos autor, dibujos de M. Oliva, 1955 y 1959).

samos entonces con una cita de Dionisio de Halicarnaso (III, 20) referida al santuario lacial de la ninfa Feronia, al comentar el famoso rapto romano de las sabinas:

"Había allí un santuario honrado en común por latios y sabinos, entre los más sacros de los dedicados a la diosa Feronia, que algunos traducen del griego "portadora de flores", otros "amante de las coronas", otros también Perséfone. A este lugar muchos concurrían de las ciudades vecinas en los días de fiesta para ofrecer votos y sacrificios a la diosa, muchos para comer- ciar durante la fiesta: mercaderes, artesanos y ciudadanos...”

Pero queremos ahora introducir en el debate un paralelo etnográfico, con todos los condicionantes que esto significa. Hace algún tiempo, conocimos gracias a un trabajo de J. Onrubia (1986) la cuestión de los graneros colectivos norteafricanos, a los que se dedicaron diversos estudios etnológicos en los años 50 y 60 (JacquesMeunié 1951; Despois 1953; Capot-Rey 1956; Gast 1968). La expresión "granero colectivo", acuñada por los estudiosos franceses, designa a la vez la estructura arquitectónica y la institución propia que ésta cobija. Han sido edificios propios de sociedades semi-nómadas, con carácter público, fortificados o situados en lugares de difícil acceso, administrados por reglamentos, vigilados y eventualmente defendidos de forma colegiada, pero en los que la propiedad se ejercía de forma individual como almacenes familiares de provisiones y pertenencias. Cada miembro de la familia, el clan o la comunidad poseía una o varias cámaras a título privado, en las que depositaba sus reservas de provisiones y generalmente sus más preciadas pertenencias, de cuyo mantenimiento era único responsable (Onrubia 1986, 283).

Todavía activos en los años 50, estos graneros colectivos se diseminaban por las zonas berberófonas de Marruecos, Argelia, Túnez y Libia occidental. El granero fortificado, normalmente ocupado con carácter casi exclusivo por una única familia patriarcal extendida, estaba administrado por un consejo de notables y custodiado por un guardián. Jugaban al mismo tiempo el papel de lugares sagrados y centros espirituales de la comunidad, sede de todos los ritos familiares y símbolo de la vitalidad del grupo.

No queremos extender más esta descripción que nos parece ya suficiente. La institución de los graneros colectivos magrebíes resulta tremendamente sugerente para plantear como pudo funcionar el sistema de relación económica entre Pontós, las granjas ibéricas de su entorno productivo y el mecanismo económico de contacto con los clientes exteriores. Esperamos que este tema pueda ser quizás tenido en cuenta con una mayor profundidad.

\section{Ullastret y l'Illa déEN REIXAC.}

Complemento indispensable de Emporion, el oppidum de Ullastret, abierto en este caso a las lagunas de la región vecina del Baix Emporda, al otro lado del Montgrí, resulta un ejemplo magnífico de gran yacimiento ibérico fortificado, situa- 
do sobre una colina que presidía una gran laguna interior alimentada por las aguas del Daró (Martin 2001). Un frente de colinas (la sierra de Llabià) separaba y ocultaba el lugar respecto a la gran llanura aluvial del Baix Emporda, entre el Montgrí (al N) y el cabo de Begur (al S).

$\mathrm{Al}$ igual que Emporion, Ullastret presenta un significativo hábitat doble. En primer lugar la colina amurallada -el Puig de Sant Andreu-, donde se levanta el oppidum, presidido por una probable acrópolis sacra ocupada más tarde por un castillo medieval del siglo XII. En segundo lugar, en el centro de la paleolaguna que se extendía a los pies del oppidum, se situaba l'Illa d'en Reixac, un montículo de dimensiones regulares cuya excavación ha proporcionado toda la secuencia de ocupación desde la Edad del Bronce hasta fines de la época ibérica, incluyendo como hemos comentado anteriormente el impacto de fenicios, etruscos y foceos, junto a la primera aparición de las cerámicas a torno ibéricas (Martin y Sanmartí-Grego 1978). L'Illa d'en Reixac fue objeto de un programa específico de investigación en los años 80 y 90 con resultados publicados en una importante monografía (Martin, Buxo, López, Mataró 1999).

El tercer yacimiento en importancia del entorno de Ullastret es el área de necrópolis del Puig de Serra, al norte de la laguna (Martin y Genis 1998). Además, los recientes trabajos de prospección dirigidos por R. Plana y A. Martin (2000; 2001) han permitido documentar numerosas evidencias de la ocupación dispersa en torno a los hábitats principales y siguiendo la vía terrestre de comunicación entre Ullastret $\mathrm{y}$ Emporion.

Los trabajos realizados desde el año 1995 en el oppidum de S. Andreu se han centrado sobre todo en la excavación de las terrazas inferiores, documentando un extenso barrio urbanizado con casas de los siglos IV y III a.C. Han podido también definirse las dos fases principales del sistema defensivo, con una primera muralla torreada datada estratigráficamente ya a fines del siglo VI a.C. y una importante ampliación en los inicios del siglo IV a.C. (400-375 a.C.) al crearse un baluarte en punta, dominante sobre el camino y el lago, que complementaba eficazmente la defensa de los accesos al oppidum (Martin 2000). Estelas epigráficas escritas en ibérico reutilizadas en la torre $\mathrm{SO}$ y en la urbanización de esta ampliación del recinto acreditan la importancia del oppidum y de sus élites ya durante la primera fase urbana (Casas et alii 2002).

Como decimos, Ullastret estaba presidido por una acrópolis sacra que por ocupar el lugar más
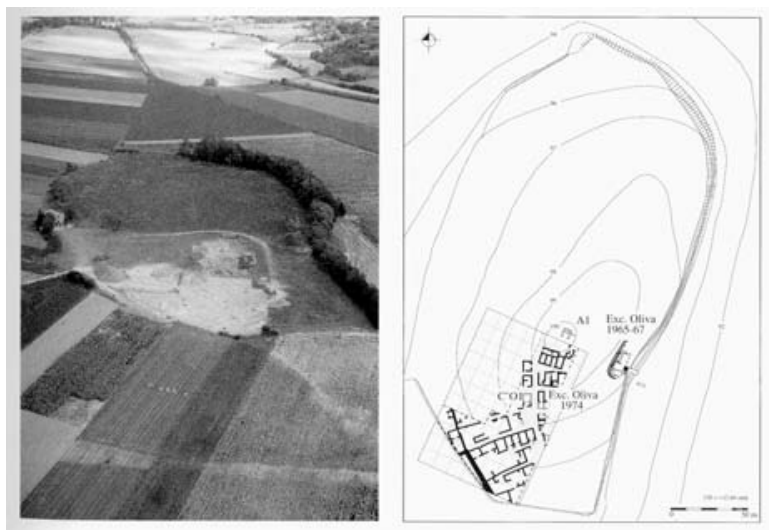

Fig. 20.- L'Illa d'en Reixac. Vista desde el sur y topografía (fotografía de J.S. Carrera en Martin et alii 1999).

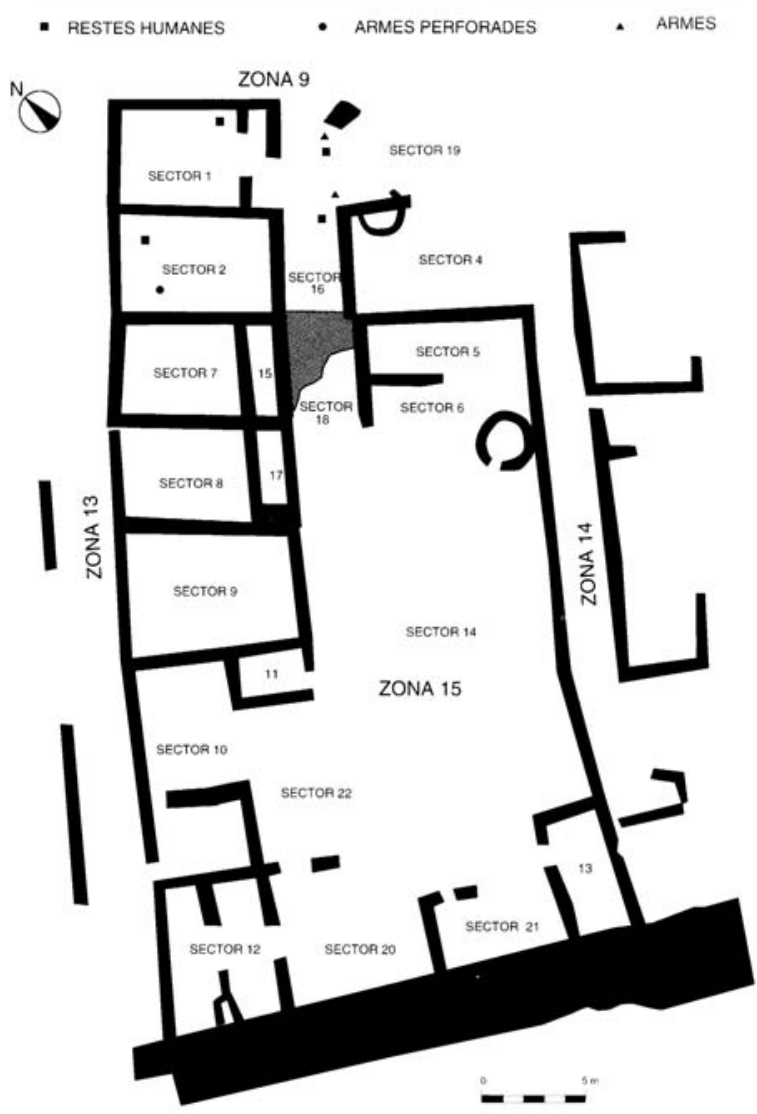

Fig. 21.- L'Illa d'en Reixac. Hallazgos de cráneos y espadas enclavadas en la casa 15 (de Rovira 1998).

elevado presenta una ocupación continuada. Las ruinas de un castillo del siglo XII dejaron paso a una ermita gótica dedicada a San Andrés y a una masía contigua, ambas reutilizadas como sede del actual Museo Monográfico. Aun así, los infatigables trabajos de M. Oliva (1955, 403ss; 1958) 


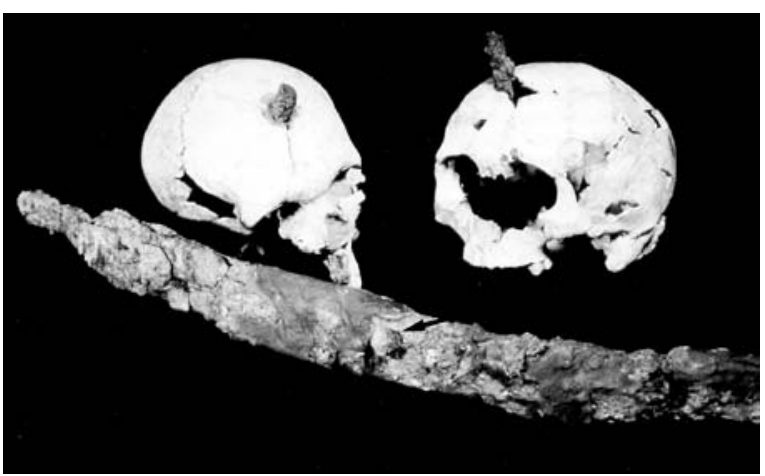

Fig. 22.- Cráneos y espada enclavados del silo 146 ( de Rovira 1998).

permitirían detectar la presencia de dos templos situados en paralelo, los restos de uno de los cuales permanecen aun visibles. En realidad, este supuesto templo presenta un muro perimetral realizado en sillería irregular con buen número de contrafuertes, cuyo uso entenderíamos para un depósito o cisterna pero no desde la perspectiva de un pequeño edificio sacro. Oliva (1955, 405-406) señaló la aparición en su interior de fragmentos de un opus signinum con decoración de teselas destrozado, con fragmentos vertidos boca abajo revueltos con materiales cerámicos ibéricos y de barniz negro junto a materiales medievales. Es pues probable que este pavimento proceda de un edificio vecino y que el templo, único, fuera en realidad el edificio contiguo hoy oculto bajo el Museo.

De cualquier forma, mayores seguridades aportan los hallazgos de M. Oliva en torno a estas estancias y en el interior de una cisterna delantera de un total de 29 fragmentos de máscaras de terracota policromadas en blanco del más puro estilo helenístico (Oliva 1955, figs. 5253; Oliva 1958, fig. 25). Estas piezas han sido analizadas someramente por M. J. Pena (1993) y de forma algo más detallada por M. Miró (1990). No se trata de antefijas. Las partes traseras planas, sin reborde superior, y algunas perforaciones permiten asegurar su carácter de máscaras de aplique. Una ofrenda votiva característica del mundo púnico pero que los griegos también utilizaron conjuntamente con las protomai.

Entre estas máscaras podemos identificar la imagen grotesca de un joven sátiro (si estuvieramos en un contexto griego en Sicilia diríamos que se trata de una máscara teatral), un fragmento de frente cornuda, atribuible a una divinidad fluvial o acuática tipo Aqueloo, y dos tipos diferentes de rostros femeninos. Uno de ellas es una cabeza joven que presenta ceñido bajo el mentón el nudo (de serpientes) que nos permite identifi- carla como un Gorgoneion, la cabeza cortada de la Gorgona. El segundo rostro, fragmentado, es una imagen femenina de expresión severa, con cabellos rizados. Bajo el pómulo derecho se intuye también el cordón de una serpiente.

Es cierto que las antefijas del templo tardorepublicano de Caravaca, cuyo origen itálico ha estudiado con detalle S. Ramallo (1993) representan ménades y junto a ellas jovenes sátiros que llevan anudadas al cuello las patas de la nebris, la piel de ciervo con que se cubrían los miembros del séquito dionisíaco. Pero en las máscaras de Ullastret el nudo ceñido bajo el mentón apunta mejor a las serpientes anudadas de un Gorgoneion tratado al modo helenístico, cuando la expresión endemoniada con lengua colgante típica del arcaismo fue sustituida por la mirada serena propia de la nueva sensualidad del arte helenístico (cf. LIMC, s.v. Gorgo-Gorgones, p.ej. num. 111, de Eretria, s. IV a.C. -I. Krauskopf-).

Los ritos dionisíacos de sátiros y ménades sin duda formarían parte de un imaginario ibero que conocía el vino desde sus propios orígenes como cultura y la expresión iconográfica de sus mitos a través de las pinturas de los vasos áticos. Una divinidad acuática de tipo griego sería también fácilmente comprensible en un oppidum que presidía un paisaje lagunar. Pero debemos también preguntarnos que papel jugaban en Ullastret estos Gorgoneia y cómo eran entendidos por los iberos. Nada podemos precisar sobre su origen concreto, pero sí recordar la fabricación en Rhode de las protomai antes citadas. En Ullastret, la importación de ritos protectores está también atestiguada por dos figuritas de terracota policromada del dios Bes, llegadas con toda probabilidad a través del comercio ebusitano.

No es necesario insitir sobre la virtudes apotropaicas que para un griego tenía el sagrado gorgoneion incorporado a la égida, el pectoral de la invulnerabilidad que Zeus regalaría a Atenea. En el frontón del templo arcaico de Artemis en Corfú, la Gorgona de cuerpo entero y mirada terrible intimidaba con su presencia al devoto, purificándole. El gran Gorgoneion esculpido en uno de los muros de la Acrópolis ateniense, sobre el teatro de Dionisos (Pausanias 1, 21, 3), era el emblema que defendía simbólicamente la ciudad ante cualquier ataque, la misma función que cumplía en Argos el túmulo cerca del ágora donde según la tradición local el propio Perseo habría enterrado la cabeza "auténtica" de Gorgona (Pausanias 1, 21, 5). Esta función defensora de la comunidad cuadraría bien en la acrópolis de Ullastret, aun si estas imágenes eran aquí 
parte de un ciclo iconográfico más amplio, que incluía tambien antefijas y acróteras no conservadas explicando con motivos "griegos" la historia y poderes de la divinidad / divinidades ibéricas.

Y en la identificación de esta divinidad puede resultar útil recordar uno de los aspectos de la Artemis arcaica que ha recordado L. Kahil (1978, 82-83): su carácter de Potnia Theron, diosa de los animales y del espacio exterior no urbanizado, que instalaba sus santuarios sobre dunas, marismas y fuentes. Una Artemis que en un plato rodio es representada explícitamente como una Potnia / Gorgona, ¿ podrían ser estas máscaras de Ullastret la única evidencia -tardía- atribuible en Hispania a los Artemisia massaliotas?

Resulta significativo que todos estos dones votivos de la acrópolis de Ullastret sean por igual máscaras que hemos de imaginar clavadas en las paredes del templo o colgadas de las ramas de algunos árboles dentro de su témenos. $\mathrm{Al}$ igual que las protomai, las máscaras fueron objetos sacros característicos del mundo feno-púnico (Ciasca 1988), pero están igualmente presentes en los santuarios de la Sicilia griega. En Morgantina, los depósitos votivos de los distintos santuarios suburbanos dedicados en su totalidad a los cultos agrícolas y femeninos a Deméter y Koré, incluyen junto las figuras y las cabecitas femeninas de terracota, también la presencia de máscaras de tipo teatral, tanto dramáticas como burlescas, que allí son interpretadas de dos formas posibles: como exvotos de los propios actores o como muestra votiva de las farsas y danzas cómicas que acompañaban la celebración de las Thesmophorias (Bell III 1981, 97-98). En los depósitos votivos de los santuarios de Deméter y Koré en el Acrocorinto, en Knossos o en el Eleusinion del ágora ateniense aparecen por igual estas máscaras dramáticas y grotescas (Bell III 1981, nota 186). Ullastret no nos permite este tipo de aproximaciones, pero nos basta con destacar el sentido culto y urbano que presupone su presencia. Como en Emporion y Pontós, también en Ullastret aparecen las figuras femeninas drapeadas (tanagras) y los mal llamados pebeteros con cabeza femenina, estos últimos aparecidos en lugares diferentes, probablemente formando parte de capillas domésticas y con una serie variada de tipos distintos.

Pero si todos estos elementos nos muestran el aspecto más helenizado del oppidum, tambien aquí aparece de forma explícita la componente celta que hemos visto en Pontós. En primer lugar a través de una serie de copas de asas y cuencos ibéricos con decoración de pequeñas cabezas aplicadas estudiadas por F. Horn (2003, núms. 20-28). Y una vez más, de nuevo volvemos a contemplar en la última fase urbana del oppidum de Ullastret la presencia de los cráneos y las espadas enclavadas.

Este rito específico era ya conocido al publicar M. Oliva en 1969 los hallazgos del silo 146 situado extramuros junto a una de las poternas de la muralla del Itsmo: dos cráneos enclavados depositados en su interior junto a una espada envainada de La Tene II en posición vertical. La espada presentaba también un clavo de perforación muy poco visible por la corrosión y que ha sido identificado mediante rayos X por C. Rovira (1998, 170-171). Su estudio le ha permitido además detectar otra posible ofrenda en la espada y clavo aparecidos en el silo 23 (Oliva 1958, fig. 18).

Dentro de las construcciones de la última fase urbanística de l'Illa d'en Reixac, datables en el siglo III a.C., los excavadores observaron las características especiales de un gran edificio singular (zona 15), adosado a la muralla, accesible por un pasillo y definido por un gran patio interior rectangular al que abrían una hilera de habitaciones y dependencias. El pavimento de la sala central num. 8, estaba decorado con alineaciones de 35 conchas dispuestas en tres hileras (Martin, Mataró, Caravaca 1997), y bajo los suelos de las dos habitaciones contiguas al pasillo de entrada a la vivienda (1 y 2 ) aparecieron los habituales depósitos de ofrendas fundacionales conteniendo vasitos miniaturizados y restos de ovricápridos.

Pero los estratos de abandono de estas habitaciones proporcionaron evidencias de los elementos almacenados en sus interiores: páteras, platitos, pequeña jarra, ungüentario, ofrendas de diversa fauna (caballo, cerdo, ovicapridos) junto a una espada envainada La Tene 1, tres mandíbulas humanas y un fragmento de cráneo. Los restos humanos continuaban en el exterior de estas dos habitaciones, a lo largo del pasillo de acceso a la gran casa, con tres nuevos fragmentos de cráneos y otro de mandíbula. El rito de las espadas y los cráneos enclavados se reproducía pues en la casa principal de esta isla amurallada en medio de la laguna (Martin, Mataró, Caravaca 1997; Rovira 1998)

A partir de 1995, la continuación de las excavaciones en el interior del oppidum del Puig S. Andreu ampliando la zona 14, un antiguo sector excavado por J. Maluquer, permitió descubrir un amplio sector urbanizado de la última fase urbana del yacimiento. Aquí, una vez más, en los denominados sectores 11 y 12 , contiguos a la muralla, aparecieron cuatro mandíbulas inferiores y tres fragmentos de cráneo (Martin 2000, 116), y junto a ellos un nuevo fragmento laminar 
de la vaina de una espada con perforación enclavada (Rovira 1998, 171).

\section{Cráneos enclavados / gorgoneia / VASOS VOTIVOS /CERNOS DE KORÉ, ¿CUES- TIONES DE CEFALOMANCIA?}

En 1955, los hallazgos de cráneos enclavados en la sala hipóstila de Entremont motivarían a F. Benoit escribir el primero de una serie de artículos dedicados al tema de la cefalomancia: la creencia multicultural en la eficacia mágica de la cabeza humana. En 1969, Benoit publicaría en ArchEspA un nuevo trabajo dedicado a este tema cuyo título nos parece ahora muy apropiado para la realidad arqueológica que estamos describiendo en Ullastret: "Gorgone et 'tete coupee', du rite au mythe". Los nuevos hallazgos nos obligan a volver de nuevo la atención hacia estas "viejas" síntesis cuyas sugerencias podemos ahora entender y discriminar mejor gracias a los nuevos hallazgos y estudios.

En Ullastret y Pontós, los cráneos enclavados o simplemente conservados tienen como paralelos directos los contextos galos bien conocidos y estudiados en las regiones de Provenza y Aude: sala hipóstila del oppidum de Entremont (c. 125 a.C.), con 22 cráneos, de ellos 6 enclavados junto a las estatuas sedentes de los ancestros heroificados; santuario de pórtico de Roquepertuse (destruido por un asalto en el II a.C.) con cráneos encajados en cavidades cefaliformes sobre pilastras rodeando idénticas estatuas sedentes de los ancestros; cráneos enclavados de Glanon en rellenos de finales del II a.C. y un dintel de piedra con encajes cefaliformes cuidadosamente dispuestos; los famosos tres cráneos enclavados sobre el dintel de la entrada principal del oppidum de La Cloche (destruido por un asalto romano a mediados del s. I a.C., Chabot 1983, Chabot y Feugere 1993); y al menos cinco cráneos en torno a un pilar-estela cerca de la entrada del oppidum de Pech Mahó (Arcelin, Dedet, Schwaller 1992, 214-226; García ed. 1992).

A estas evidencias hemos de añadir además las imagenes escultóricas y los relieves en piedra con idéntica simbología, ya que en Entremont las estatuas de la sala hipóstila con los héroes sentados con las piernas cruzadas sobre altos zócalos estaban también rodeados de pilastras mostrando grupos de cabezas cortadas y una de las estatuas hacía ostentación de un lote de cabezas apiladas (Deyts 1992, 12-13; Arcelin, Dedet, Schwaller 1992, 216-225; Salviat 1993).

También aparecen estas ofrendas craneales en los grandes santuarios de Picardía como Gournay o Ribemont, la germana Manching o la británica Danebury con una abundante bibliografía (Bruneaux 1989; 1993). Y hoy sabemos además que se trató de una costumbre ritual también extendida entre diferentes pueblos hispánicos. La ofrenda de un cráneo femenino acompañando a un depósito votivo subterráneo en Garvao (Ourique, PT) a fines del siglo III a.C. acredita esta práctica como ofrenda sacra entre los lusitanos, mientras que una ofrenda similar se ha documentado recientemente de forma magnífica entre los astures, con el cráneo conservado dentro de una cista y enterrado bajo el acceso principal al castro de Chao Sanmartín en Navia (Villa 2003).

Los autores griegos, por su parte, quedaron impresionados por los trofeos militares galos. Aunque se trata de citas bien conocidas (Arcelin, Dedet, Schwaller 1992, 216; Horn 2003) queremos recordar de nuevo por su claridad las menciones coincidentes de Diodoro y Estrabón referidas a como los galos practicaban la decapitación de los enemigos vencidos y su conservación como trofeos:

"[Los galos] cortan la cabeza a sus enemigos muertos y las cuelgan del cuello de sus caballos y despues de entregar a sus servidores los despojos ensangrentados los llevan como trofeos cantando un peán y entonando una canción de victoria, y ellos clavan en sus casas estas primicias del botín como si se tratara de cacerías en que hubieran abatido fieros animales. En cuanto a las cabezas de sus enemigos más ilustres, impregnadas de aceite de cedro, las conservan con gran cuidado dentro de un cofre y las muestran a los extranjeros, glorificándose de que por tal o tal cabeza uno de sus ancestros o su padre o él mismo había rechazado una gran suma de plata..." (Diodoro $\mathrm{V}, 29$ )

"[En los galos] su falta de reflexión es acompañada de barbarie y salvajismo, como ocurre a menudo con los pueblos del Norte: pienso en la costumbre que consiste en suspender del cuello de su caballo las cabezas de sus enemigos cuando vuelven de la batalla y llevarlas con ellos para clavarlas delante de las puertas principales (propilaia). Poseidonio dice haber visto él mismo este espectáculo en muchos lugares, que al principio le repugnaba, pero al que acabó finalmente por acostumbrarse. Embalsamaban con aceite de cedro las cabezas de sus enemigos ilustres para mostrarlas a los extranjeros y rechazaban venderlas aunque fuera a cambio de su peso en oro...” (Estrabón, IV , 4,5).

Tal sería la funesta suerte del procónsul L. Postumius, emboscado por los boyos de la Galia Cispadana en un bosque cercano a Módena en el 
216 a.C., cuya cabeza acabó incrustada en oro sirviendo como vaso de libaciones para el sacerdote del templo principal de sus vencedores en una cita recordada por Livio (XXIII, 24, 11-12). Pero Diodoro (XIII, 56) también menciona una costumbre bélica similar entre los mercenarios iberos utilizados por los púnicos contra Agrigento:

"[Los iberos] mutilaban los cuerpos según los usos de su pueblo, algunos llevaban con ellos racimos de manos colgadas al cinto y otros cabezas ensartadas en jabalinas y estacas)".

Manos cortadas, lanzas verticales (Arist., Polit. 1324b: y los iberos, pueblo belicoso, clavan alrededor de sus tumbas tantas lanzas como enemigos hubieran muerto en combate) y cabezas humanas aparecen repartidas en los pedestales funerarios ibéricos al norte del Ebro (La Vispesa en Tamarit de Llitera, estela ibérica de Cretas, estela de S. Martí Sarroca, etc.), evidenciando un ambiente cultural "galo" sobre el que se llamó la atención en los años 70 (Guitart 1975; Maluquer 1978, 180). F. Quesada (1997) siempre nos ha recordado que el armamento ibérico del noreste

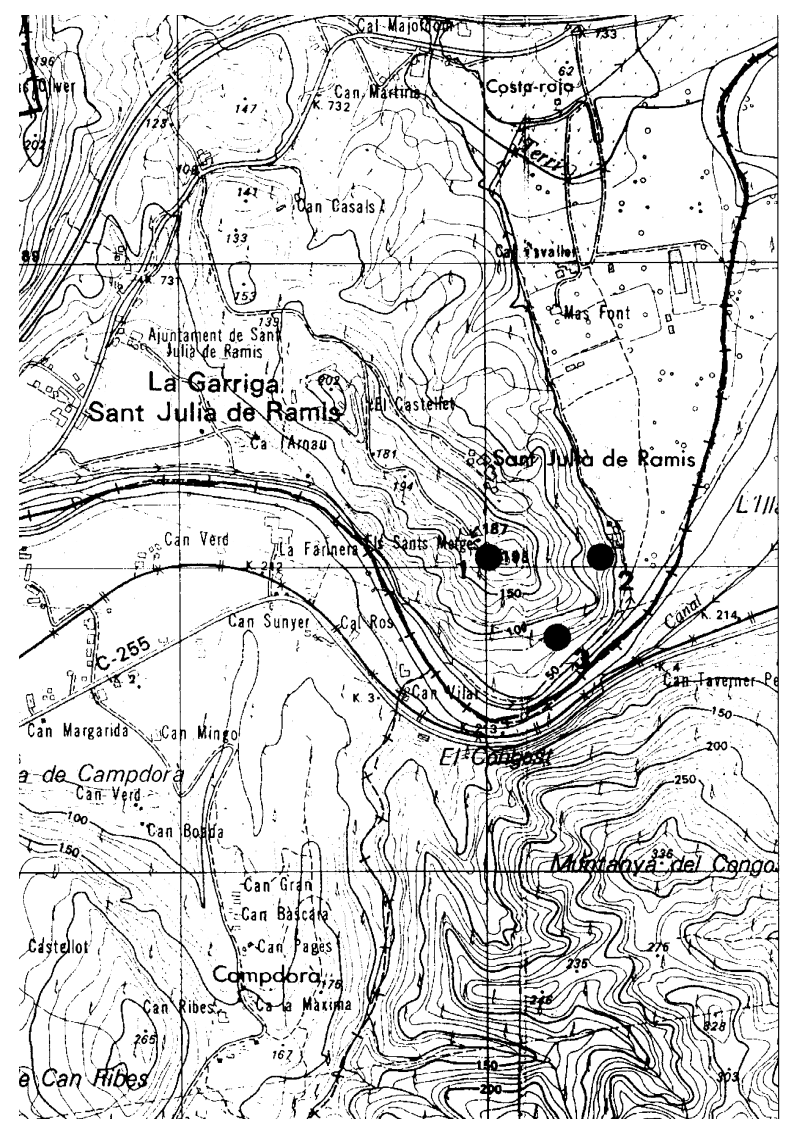

Fig. 23.- Panta topográfica de S. Julià de Ramis (de Agustí et alii 1995). 1. Oppidum ibérico y templo romano. 2. Campo de silos del Bosc del Congost. 3. Villa romana. hispano, con presencia abrumadora de largas espadas rectas de La Tène, tiene muy poco de "ibero" y mucho de "celta". C. Rovira (1998) ha dedicado un trabajo específico a esta asociación de cráneos y espadas enclavadas en los yacimientos de Pontós, Ullastret, Turó del Vent (Llinás del Vallés), el Puig Castellar de Sta.

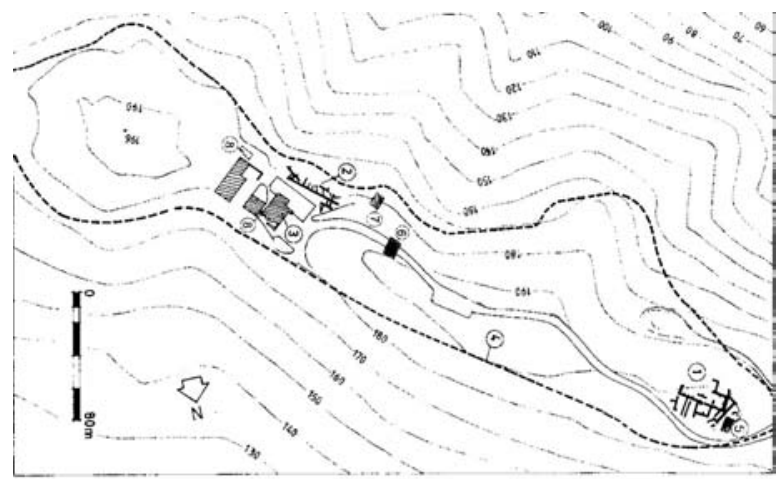

Fig. 24.- Planta general del oppidum de S. Julià de Ramis (de Burch et alii 2001).

Coloma y Tornabous. Por su parte, F. Horn (2003) ha estudiado de forma detallada esta cuestión a partir de las decoraciones plásticas con cabeza humana en cerámicas ibéricas y celtibéricas, contextualizando de forma amplia y útil los ritos de la cabeza cortada.

Junto a esta imagen "celta" de los cultos heroicos encontramos en Ullastret elementos de clara raigambre helénica pero que curiosamente conducen de nuevo al tema iconográfico de la cabeza cortada: máscaras de terracota (cंofrendadas como exvotos?) con la cabeza de la Gorgona cortada por Perseo; pequeñas copas votivas ibéricas en cuyos laterales vuelven a aparecer cabecitas con un tratamiento muy rústico. En último lugar, la cabeza de una tanagra del silo de Pontós y los mal llamados pebeteros con cabeza femenina nos muestran una amplia iconografía votiva girando en torno a la cabeza humana, pero esta vez ligada a la paz, la procreación y el trabajo femenino en el interior de los hogares.

En el mundo griego las cabezas femeninas surgiendo de la tierra representaban el ánodos o ascensión de Perséfone que abandonaba a Hades, su raptor y ahora marido en los Infiernos, para volver a ser la hija Koré reclamada por su afligida madre Deméter. En sincretismo o adaptación directa con ritos púnicos, itálicos e ibéricos, las terracotas con cabeza de Koré testimonian con su presencia en capillas domésticas, templos y tumbas el más popular de los ritos agrarios circunmediterráneos, expresión anual de las ceremonias que acompañaban a las actividades de la siembra y la cosecha (Ruiz de Arbulo 1994 b). 
Este mestizaje que contemplamos una y otra vez en el mundo ibero indiceta es también característico del mundo celta que rodea Massalia. Un caso paradigmático es el de Glanon / Glanum, el santuario del dios Glan y las Madres Glánicas nacido junto a un manantial situado en un desfiladero rocoso cercano a St. Remy de Provence. Allí se sucedieron durante el siglo II a.C. magníficos edificios del más puro estilo helénico (muralla almenada que servía de períbolos, pozo con dromos de acceso, bouleuterion, pritaneon, etc.) y junto a ellos también edículos para héroes sentados con las piernas cruzadas como los de Roquepertuse y Entremont, rodeados por pilares decorados con caballos pintados (Glanum 1989; Barbet 1991; Roth Conges 1992). Edificios griegos para la religiosidad de una población de onomástica únicamente celto-ligur, con dioses plenamente indígenas, que fue atacada por Roma a fines del siglo II a.C., sitiada y tomada al asalto, como atestiguan las piedras de catapulta, para ser más tarde sustituida por una nueva ciudad de corte itálico: la Glanum tardo-republicana.

\section{El fin de Ullastret y Mas Castellar de Pontós.}

Si los hallazgos dispersos y amontonados encima de los pavimentos en Mas Castellar de Pontós parecían propios de una destrucción violenta que había acabado con la vida en el yaci- miento, otro tanto parece suceder en el oppidum de Ullastret. J. Oliva había ya observado labores de emparedamiento defensivo en la puerta principal, un fenómeno ahora bien documentado en el Castellar de Meca y otros yacimientos del Levante destruidos por ataques romanos. Además, la dispersión de materiales por el yacimiento con idénticas cronologías apuntan a una destrucción generalizada seguida de un abandono que se produce en los inicios del siglo II a.C., la misma fecha observada en Pontós.

Resulta pues necesario remarcar estos hechos arqueológicos singulares recordando los acontecimientos bélicos de la campaña del cónsul Catón en el año 195 a.C. descritos por Livio (Martínez Gázquez 1974). Una de las eras (areae) saqueadas por Catón para aprovisionar a sus tropas bisoñas según el relato de Livio fue sin duda Pontós, y el abandono definitivo del gran oppidum de Ullastret que durante dos siglos había jerarquizado el territorio de los indicetas, tuvo que ser consecuencia de la derrota ibérica en la famosa batalla cercana a Emporion. Una batalla en la que según Livio el cónsul rodeó el campamento de los iberos en rebeldía (castra hostium) en una maniobra audaz para obligar a sus tropas a un ataque sin posibilidad de retirada.

Tras la batalla, el campamento, descrito por Livio (XXXIV, 15) como si se tratara de unos castra legionarios con empalizada y diversas puertas, fue conquistado al asalto con ayuda de la

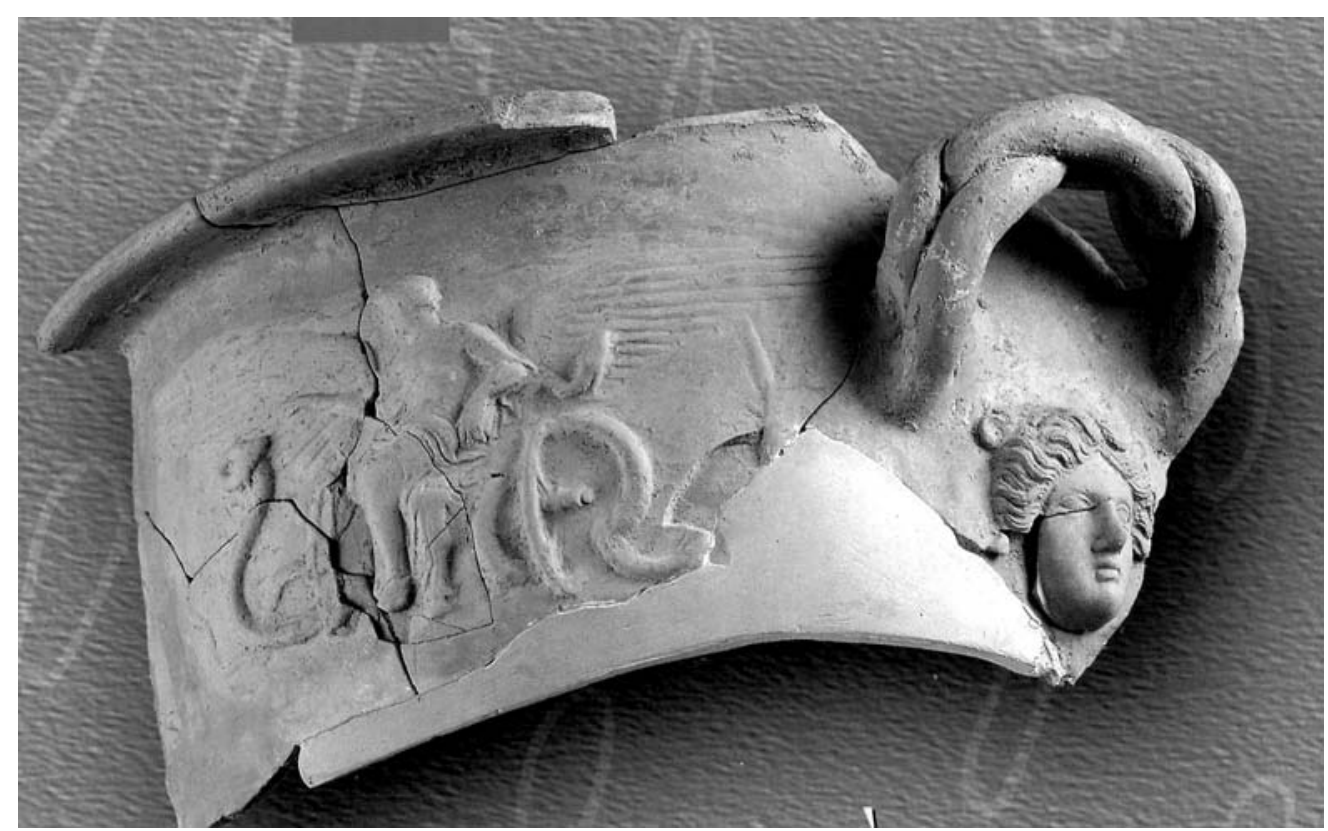

Fig. 25.- S. Julia de Ramis. Campo de silos del Bosc del Congost. Cálato ibérico aparecido en el silo 53, con decoración aplicada a relieve mostrando la imagen de Triptólemo (de Agustí et alii 1995). 


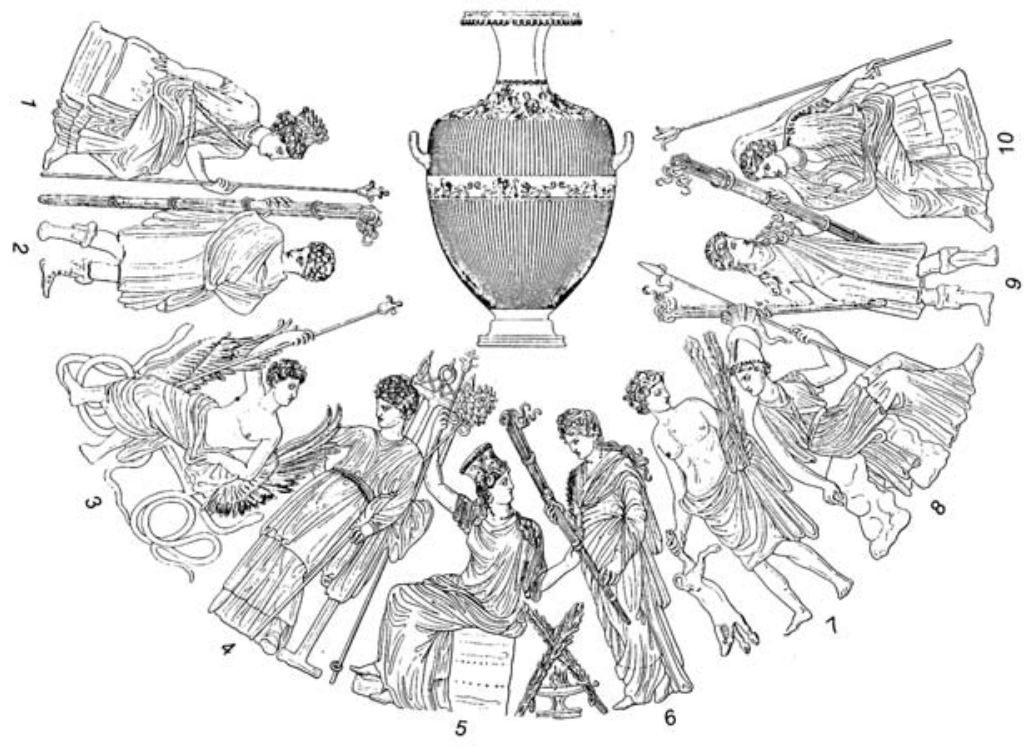

\section{EL OPPIDUM Y CAMPO DE SILOS DE S. Julià de RAmis (GIRONA).}

En la Antigüedad, el río Ter podía remontarse desde su desembocadura en el puerto emporitano, atravesando la zona de lagunas y marismas litorales en torno al Montgrí, para ganar altura lentamente entre llanos y colinas onduladas penetrando después en la comarca del Gironès cortando las sierras de baja altura. Antes de llegar a su confluencia con el río Onyar, donde Roma levantaría la nueva fundación de Gerunda en las primeras décadas del siglo I a.C., el río debía atravesar una garganta

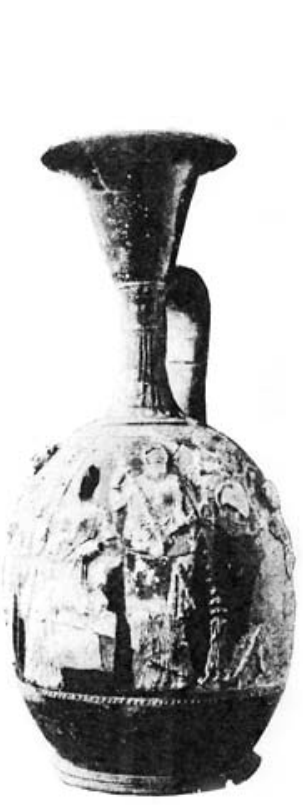
angosta y alargada presidida por la colina de S. Julià de Ramis: un esperón de unos 500 m. de longitud y $80 \mathrm{~m}$ de anchura con una cota máxima de 197 m.s.n.m. Esta colina alargada y escarpada está hoy ocupada por la iglesia dels Sants Metges y el cementerio municipal del vecino pueblo de S. Julià, junto a los cuales aparecieron los restos de un poblado iberico localizado por F. Riuró en los años 30, e investigado despues por J. Maluquer e I. Rodà (cf. Agustí, Burch, Merino 1995, 88-90).

En 1991 y 1992 todo el entorno de la estrecha garganta fluvial fue objeto de importantes trabajos arqueológicos de salvamento al construirse una nueva variante de la carretera N-II rodeando Girona. Estos trabajos permitieron localizar yacimientos de diversas épocas entre los que ahora destacamos el campo de silos excavado en el Bosc del Congost (Agustí, Burch, Merino 1995; Agustí et alii 1998). Desde 1996, un proyecto de investigacion de la Univ. de Girona investiga los yacimientos de lo alto de la colina: los restos del oppidum ibérico, un mausoleo tardo-antiguo y un castellum que controlaba el paso de la vía Augusta. Reaprovechados en la construcción de éste último, aparecen hasta 40 bloques desmontados de un templo monumental romano en piedra (Burch et alii 2001, 98-107). En realidad, esta vía terrestre tardo-antigua vigilada desde $\mathrm{S}$. Julià no es sino la mítica via Heráclea prehistórica, camino inmemorial de transhumancia, convertida a fines del siglo II a.C. en la vía romana amojonada que mencionaran Polibio y Estrabón.

El poblado ibérico de $\mathrm{S}$. Julià comenzó a ser habitado en el siglo VI a.C. y dos siglos más tarde estaba ya dotado de un hábitat doméstico diferenciado con casas simples unicelulares y 
también casas complejas de hasta 7 departamentos. La extensión del poblado en estos momentos no puede ser de momento precisada pero en su momento de mayor extensión alcanzó las 4 ha de superficie.

Los 119 silos excavados en el Bosc del Congost se encuentran situados en la falda de la montaña, a lo largo de una estrecha parcela de $2000 \mathrm{~m} 2$, en posicion claramente extraurbana a $2 \mathrm{kms}$. de distancia del oppidum y claramente desplazados respecto a los campos de cultivo del entorno. Esta concentración se sitúa a apenas 50 m. del cauce fluvial actual. Los niveles de amortización de los silos que han proporcionado materiales datables han permitido cuantificar 15 rellenos datables en los siglos IV-III a.C. mientras que otros 60 silos fueron obliterados a lo largo de los siglos II y I a.C. El equipo de investigación concluye que la situación de estos silos ha de ser explicada en función del río y la exportación de los excedentes locales de cereal hacia el puerto emporitano (Agustí, Burch, Merino 1995; Agustí et alii 1998).

El repertorio cerámico aparecido en estos rellenos muestra un $93 \%$ de vajilla ibérica, en buen número ánforas y tan solo un 5\% de importaciones de vajilla ática de b. negro, y más tarde barniz negro de Rosas y Campaniense A y B, junto a ánforas massaliotas, ebusitanas, cartaginesas e itálicas y algunos elementos residuales de cerámica común itálica y cartaginesa y un mortero itálico (Agustí et alii 1998).

\section{Triptólemo en S. Julià de Ramis.}

Pero el elemento más singular de este campo de silos es una pieza única del todo excepcional aparecida en el relleno del silo 53. La parte superior de este silo estaba cortada por la erosión y los estratos de relleno se concentraban sobre un nivel de tierra quemada situado en la parte media del silo, sobre un relleno estéril (Agusti et alii 1998, 85-89, y fig. 10). Encima de esta "tierra quemada" (¿'hemos de identificar una éschara como la de Pontós?) apareció un vertedero con 467 fragmentos cerámicos -en su mayoría informes y sin conexión- de cerámica ibérica pintada, común ibérica, ánfora ibérica, gris y oxidada emporitanas, además de fragmentos de ánfora massaliota, punicoebusitana y grecoitálica, sin presencia de material de barniz negro. Los excavadores datan estos niveles a partir de la tipología de los platos emporitanos en la primera mitad del siglo II a.C. Pero entre las tierras cenicientas aparecieron también varios fragmentos del borde y cuerpo de un cálato ibérico con asas trenzadas, cocción oxidante y engobe marrón, una pieza característica de la vajilla ibérica, pero que presenta la única decoración en relieve hasta ahora documentada en este tipo de vasos. La decoración no puede ser más significativa para la problemática que venimos exponiendo porque aparece nada menos que el héroe Triptólemo cabalgando sobre su carro alado tirado por serpientes y una cabeza frontal situada debajo del asa.

La pieza ha sido ya presentada en diversas ocasiones (Burch et alii 1993; Agusti et alii 1995; 1998) pero todavía no ha tenido creemos un reconocimiento suficiente de su importancia. Bajo el asa trenzada aperece una imagen femenina frontal con un peinado de cabellos ondulados y ralla central ceñida por una diadema que parece acabada en dos bucles. Presenta un tratamiento de busto que recuerda al ánodos o "surgimiento" de Koré. Un busto semejante corona una placa votiva de Eleusis realizada en mármol acompañando una imagen de ojos (representando a la divinidad que "todo lo ve") y una dedicatoria a Deméter (Clinton 1992, fig. 78); pero no sabemos identificar esta imagen con precisión. Por el contrario, la actitud independiente de Triptólemo acariciando la cabeza de una de las serpientes con el chitón anudado en la cintura, y su posición lateral junto al asa permite imaginar con toda probabilidad que el vaso estaba decorado en todo su perímetro con cuatro o cinco personajes del amplio ciclo eleusino que encontramos en la hidria de Cumas o la urna Lovatelli: Deméter, Koré, Hades, Pluto, Yakos, Eumolpos, Euboleos, los iniciados Dionisos y Heracles, Atenea..., que en los relieves votivos de Eleusis aparecen además acompañados por los sacerdotes e iniciados (mistai) junto a los objetos sacros necesarios para el culto (cf. Mylonas 1961; Clinton 1992).

Creemos que este vaso único tuvo que ser fabricado en Emporion, cuyos talleres cerámicos fabricaban indistintamente en los siglos III y II a.C. cerámicas ibéricas junto a las emporitanas grises y oxidadas (Conde 1992). El ceramista que modeló este vaso conocía la tipología de las cerámicas ibéricas pero también las nuevas modas mediterráneas y supo crear un "vaso de relieves" imitando la nueva vajilla de lujo inventada a fines del V a.C. por el ateniense Jenofantes que tuvo la fantasía de decorar los lecitos con pequeños relieves dorados (Courby 1922). La moda pasó después a imitar la rica vajilla en plata y bronce y se popularizó entre las sociedades helenísticas en los siglos III y II a.C., ya fuera mediante los boles con relieves antes llamados "megáricos" y que sabemos fueron producidos en Atenas (Hausmann 1959; Rotroff 1982) y la 
Jonia (Lamonier 1977); los cuencos decorados con escenas homéricas en relieve acompañadas de explicaciones producidos en Beocia, o los bellísimos "jarros ptolemaicos" fabricados en fayenza con imagenes en relieve de las reinas de la dinastía Lágida del siglo III a.C., (Thompson 1973). Al mismo tiempo, los talleres itálicos de vajilla de barniz negro, sobre todo en Cales, comenzaron también a incorporar relieves figurados a la vajilla de pequeño formato: páteras con medallón central, fíalas umbelicadas, ascos y gutti (Pagenstecher 1909).

En el catálogo de G. Schwarz (1987) dedicado a la iconografía de Triptólemo aparecen recogidas tan solo cuatro imágenes en relieve sobre vasos cerámicos de los que este calato será ahora el quinto ejemplar. Son todas ellas piezas de gran lujo: la Regina Vasorum o Hidria de Cumas, hoy en el Hermitage, una magnífica hidria ática con cuerpo agallonado y diez personajes del ciclo eleusino representados en un relieve adaptado a la ligera curvatura del arranque del cuello; el lecito de Kertch, hoy en el Louvre, con los distintos personajes representados en relieve a gran tamaño llenando todo el cuerpo del vaso; ambos vasos del siglo IV a.C. Han de añadirse otros dos ejemplares más sencillos producidos en los talleres de Cales en los siglos III y II a.C.: un guttus encontrado en Capua y un ascos procedente de Apulia conservado en el Museo de Nápoles (Schwarz 1987, 163-167, núms. V 149-152; v. imágenes en Courbin 1922, láms V y VI; también Clinton 1992, figs. 17-19 -friso de la hidria de Cumas-). No es posible en este contexto proponer una cronología precisa para este cálato de $\mathrm{S}$. Julià pero si observar que todos estos materiales mediterráneos orientales o itálicos llegaban a las costas ibéricas durante siglo III a.C. e inicios del II a.C. siendo sustituidas casi completamente por la nueva producción masiva de bajo coste de la Campaniense A en torno al 150 a.C. Una cronología que cuadra perfectamente con lo observado por los excavadores en el yacimiento sin permitirnos mayores precisiones.

Se ha discutido a menudo cual era la función de los cálatos ibéricos que sabemos exportados a los puertos itálicos en el siglo II a.C. (Conde 1992). Tanto su forma como el nombre con que nos son conocidos conducen directamente a los $k a l a t h o i$, los vasos utilizados en los gineceos helénicos para contener la lana durante el cardado. Unos vasos, por lo tanto, que debían ser propios del mundo femenino ibérico pero en cuyas decoraciones pintadas aparecen en ocasiones magníficas decoraciones de caza y guerra asociables con mitos o escenas emblemáticas. No fue por tanto casual el soporte que el ceramista empori-

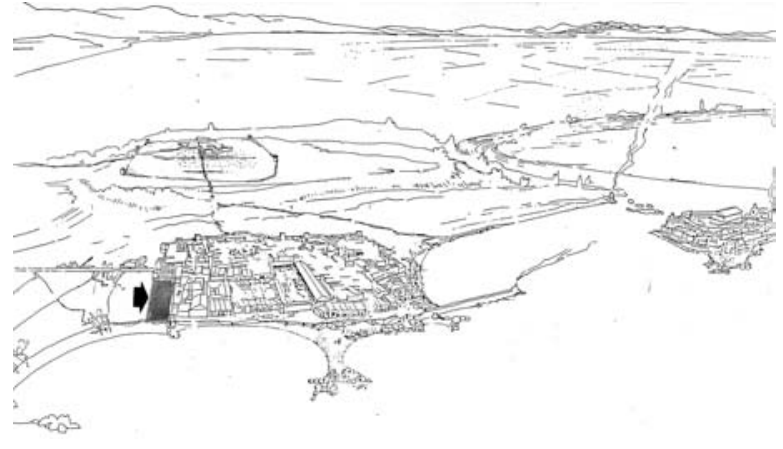

Fig. 27.- Vista de Emporion en el siglo II a.C., con la Neápolis remodelada y el nuevo castrum romano en lo alto de la colina, rodeado de un campo de silos (dibujo de R. Mar en Mar y Ruiz de Arbulo 1993). La trama señala el lugar de construcción del nuevo gimnasio.

tano escogió para su "novedad artística" insertando una decoración en relieve del ciclo eleusino ¿Pero que hacía una pieza así en un campo de silos al pie del oppidum de S. Julià de Ramis? La búsqueda de la inmortalidad por los iniciados en los misterios eleusinos era un tema secreto de tremenda trascendencia como para convertirse en un mero pasatiempo iconográfico itinerante. Sus personajes, además, resultaban incomprensibles fuera del estricto y selecto grupo de los iniciados (Mylonas 1961; Clinton 1992). Pero entre las divinidades eleusinas Triptólemo y su carro alado revisten una importancia singular y casi ecuménica pues les corresponde el mérito de divulgar con su enseñanza la cerealicultura. De la misma forma que en Pontós se entregaron sin dudar útiles agrícolas en perfecto uso como ofrenda votiva subterránea a las grandes diosas, también esta pieza excepcional pudo ser ofrendada dentro de un silo transformado en bothros, quizás sobre un hogar / altar central, más tarde afectado por la erosión. Pero también es posible, como piensan los excavadores, que se tratara de una pieza singular amortizada junto a otras muchas en un basurero cerámico posterior.

De cualquier forma, este campo de silos, almacén de excedentes agrícolas junto al puerto fluvial, parece que estuvo de nuevo "señalizado" mediante rituales religiosos concretos en los cuales los comerciantes emporitanos introducían hábilmente su propio imaginario sacro. Una herramienta sin duda destinada a favorecer los contactos comerciales con ocasion de las grandes fiestas anuales. Y una vez más debemos señalar el papel importante que en todo este fenómeno pudieron jugar los "misioneros" itinerantes, portadores de los imprescindibles objetos sagrados (hiera) que conocemos a través de ejemplos con- 


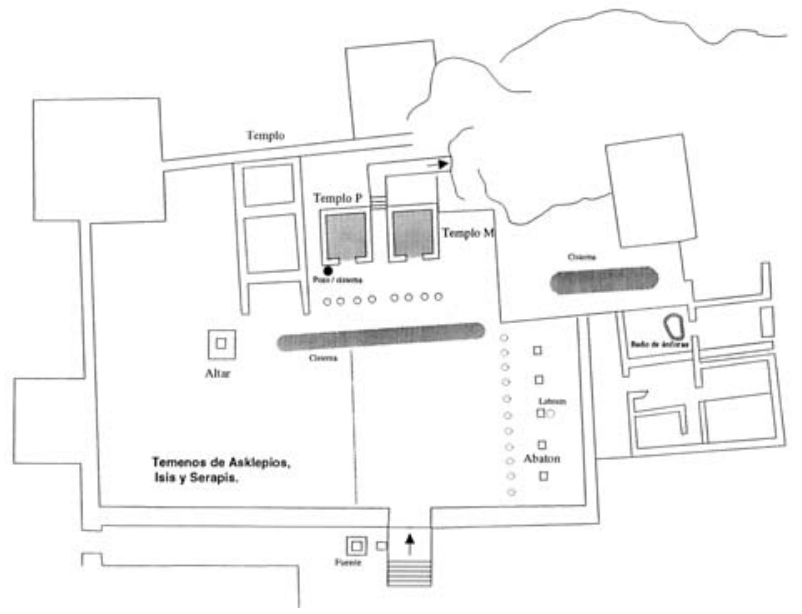

Fig. 28.- Restitución esquemática de la última fase del santuario de Asklepios, Isis y Serapis (de Ruiz de Arbulo1995 a).

cretos en la difusión mediterránea de los culto alejandrinos de Isis y Serapis (cf. Mar y Ruiz de Arbulo 2001, 312-313).

La vida en S. Julià de Ramis se prolongó a lo largo del siglo II a.C. superando en varias décadas el final de Ullastret y Pontós y quizás sustituyéndoles, pero finalmente fue abandonado al

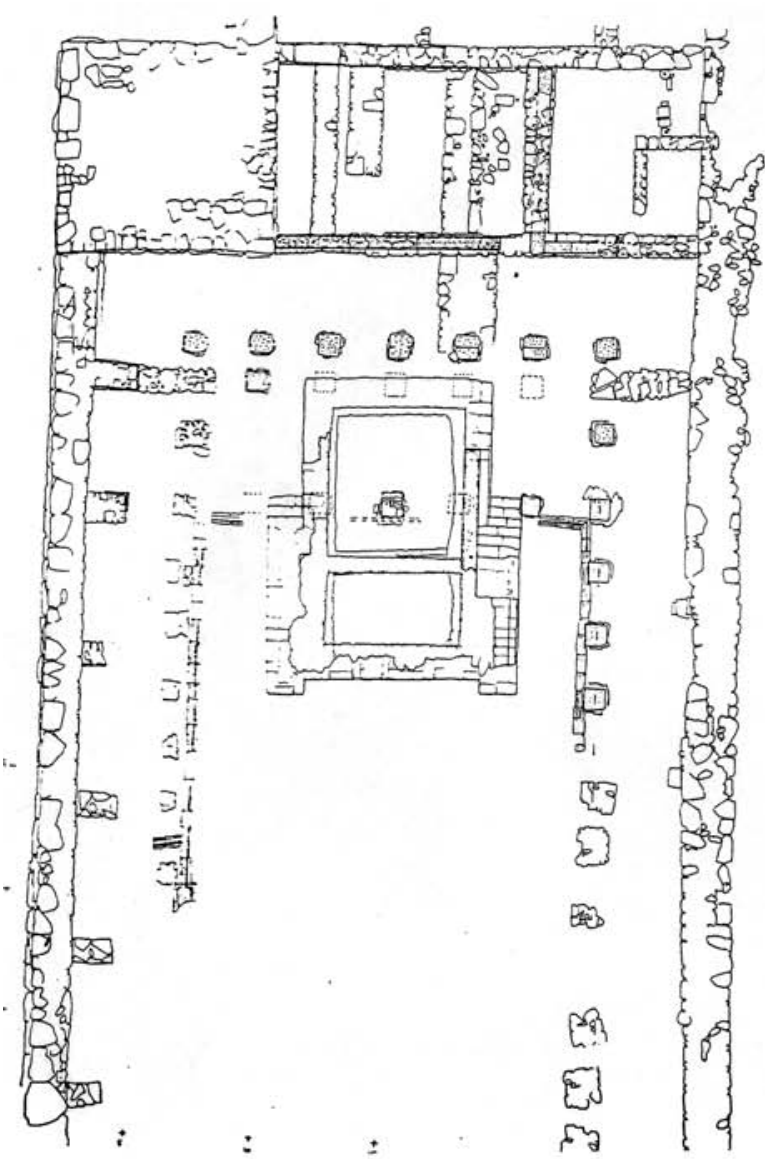

producirse la nueva fundación urbana de Gerunda en la primera mitad del siglo I a.C. Significativamente, el oppidum abandonado dejó paso en lo alto de la colina a un gran templo en piedra levantado sobre un podio forrado con ortostatos. La presencia de este templo, de tamaño excepcional para los usos de la región, nos justificaría la existencia precedente de un santuario que señalizaba y sacralizaba el emporion de la garganta fluvial. Con su construcción, como ocurriera en los grandes santuarios ibéricos meridionales (Ramallo 1993 b), Roma levantaba en piedra un nuevo mensaje iconográfico de control del territorio dirigido a las viejas y nuevas comunidades del entorno.

\section{El FINAL DEL MUNDO IBÉRICO Y LA NUEVA RIQUEZA DE EMPORION}

Al igual que Massalia, Emporion fue siempre una aliada fiel de Roma. Emporitanos y saguntinos acudieron a Roma ante el peligro que les representaban los Bárquidas, provocando la firma del tratado del Ebro en el 226 a.C.; en Emporion desembarcaron por primera vez en Hispania los legionarios romanos de Cn.

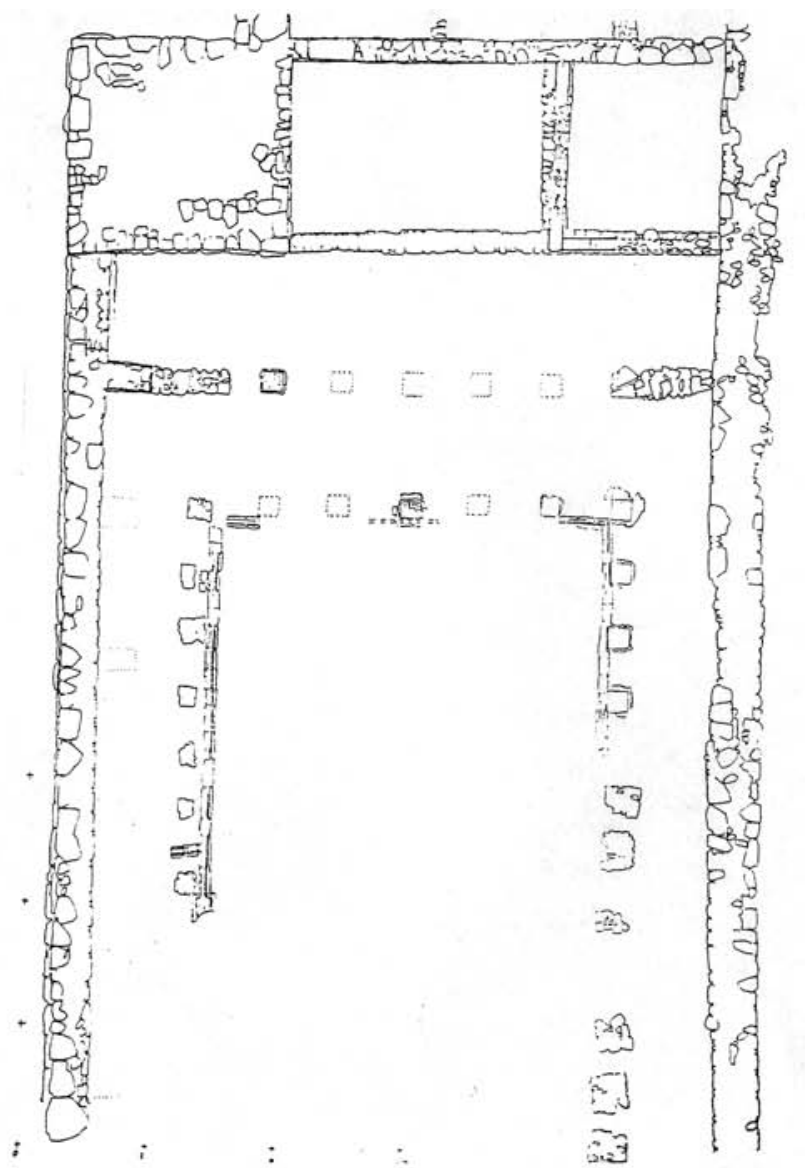

Fig. 29.- Fases constructivas del gimnasio de la Neápolis (denominado tradicionalmente santuario de Serapis). A la derecha, fase inicial correspondiente al gimnasio (s. II a.C.). A la izquierda, transformación global (en torno al cambio de Era) y construcción de un templete sobre podio dedicado probablemente al culto imperial. 
Escipión en el 218 a.C. y la ciudad destinó sus nuevas acuñaciones de dracmas al pago de las tropas romanas en el transcurso de la guerra. En el 195 a.C., frente a la rebelión de los iberos, Catón encontró en Emporion una ciudad "neutral" que le facilitó todo lo necesario en los dificiles momentos iniciales de una campaña en suelo hostil (cf. Mar y Ruiz de Arbulo 1993).

Amparada por su amistad con Roma, Emporion fue adquiriendo a lo largo del siglo II a.C. un nuevo estatuto económico y político que confirman por igual las fuentes escritas y la Arqueología. La Emporion del siglo I a.C. que describió Estrabón era la ciudad dueña de un amplio territorio (chora) que se extendía hasta las vertientes del Pirineo y las tierras del interior, incluyendo también el dominio sobre Rhode,
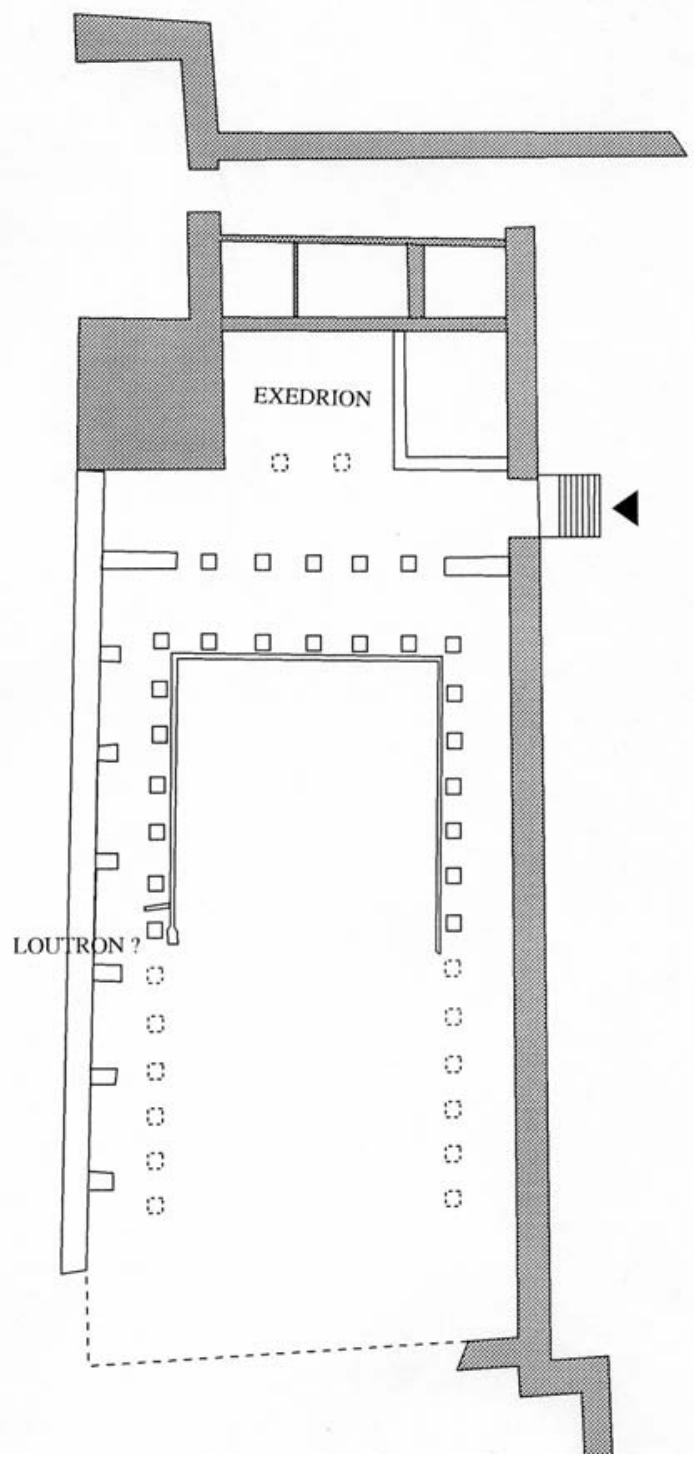

Fig. 30.- Restitución esquemática del gimnasio de la Neápolis de Emporion (de Ruiz de Arbulo 1994 a). definida ahora por Estrabón como una pequeña ciudad o factoría (polikhnion). El barrio ortogonal de los ceramistas del siglo III a.C. en Rhode fue abandonado sin solución de continuidad, por lo cual asistimos a un nuevo traslado del hábitat que controlaba el fondedero. Una situación pues que debemos interpretar estrictamente como el resultado directo de la acción romana a lo largo del siglo II a.C. y de una política de alianzas análoga a la ejercida por C. Sextio Calvino respecto a Massalia: la chora emporitana, tal como la describe Estrabón, tuvo que ser un regalo de Roma (Ruiz de Arbulo 1992).

Con ello, la ciudad emprendió a lo largo del siglo II a.C. una transformación urbanística sin precedentes de toda la Neápolis (Mar y Ruiz de Arbulo 1993): nuevo recinto amurallado; ampliación del ágora con la construcción de una monumental stoa de doble nave con locales traseros, nuevas casas "a la moda", con peristilo o atrio y peristilo pavimentadas con mosaicos de opus signinum y cartelas escritas en griego. Entre estas reformas, dos elementos singulares nos acreditan la bonanza económica emporitana y su nueva situación social: la transformación del tradicional santuario suburbano en un santuario poliado intramuros en el que un comerciante alejandrino levantaría un nuevo témenos a Isis y Serapis (IRC III, 15; Ruiz de Arbulo 1995 a) y la construcción vecina de una palestra o gimnasio (Ruiz de Arbulo 1995 b).

En 1987, la espectacular unión por G. Fabre, M. Mayer e I. Rodà de los dos fragmentos de la lápida bilingüe greco-latina IRC III, 15, permitieron finalmente su comprensión como una dedicatoria del alejandrino Numas, hijo de Numenio, de un templo, con estatuas y un pórtico a Serapis (e Isis). Dado que uno de estos dos fragmentos apareció en una cisterna contigua al santuario denominado de Asklepios, pudimos abandonar la interpretación tradicional propuesta por J. Puig i Cadafalch y seguida después sin discusión de denominar "templo de Serapis" a un recinto porticado que amortizaba la nueva muralla de la Neápolis pero cuyo templete central, sobre podio y con escaleras laterales, se insertaba claramente sobre una construcción anterior.

Propusimos entonces considerar el recinto superior como un santuario compartido por Asklepios, Isis y Serapis (Ruiz de Arbulo 1995 a). Al mismo tiempo, una reinterpretación de $\mathrm{S}$. Schroeder (1996) de la gran estatua marmórea de Asklepios como un original helenístico del siglo II a.C. correspondiente a una imagen con cornucopia y sin serpiente, le condujo hacia la iconografía de Serapis, pero la ausencia de la habitual 
túnica bajo el manto le hizo proponer mejor un monumental y muy poco usual Agathos Daimon. En realidad, la huella de grapa superior que presenta la estatua (ipara situar un cálato sobre la cabeza?) nos debe permitir reconocer una imagen de Serapis tratada al modo tardo-republicano (como la estatua conocida en Delos) todavía sin el himatión pegado al cuerpo bajo el chitón que caracterizará después a las copias imperiales del famoso Serapis de Alejandría.

Los comerciantes mediterráneos de paso por Emporion dispondrían así del solaz proporcionado por los locales de ocio emplazados en la gran stoa monumental del ágora (Mar y Ruiz de Arbulo 1988) y al mismo tiempo gozarían de la protección de los dioses de la navegación, cuyos santuarios oraculares, curativos y residenciales, fueron también cajas de depósito y lonjas de contratación, las mismas virtudes que hemos imaginado para los Artemisia del arcaismo, pero ahora ya plenamente acreditados por la documentación epigráfica y arqueológica (Bruneau 1970, 1978; Ruiz de Arbulo 1999, 28; Mar y Ruiz de Arbulo 2001).

Además, los emporitanos levantaron en el siglo II a.C. un amplio recinto porticado junto a la entrada fortificada de la ciudad: un gran peristilo o patio porticado relacionado con una gran sala axial separada del pórtico por una nave transversal. Analizando los paralelos para una estructura arquitectónica de este tipo rechazamos los santuarios heroicos de época helenística y el Pompeion ateniense para comprobar que la planta correspondía de forma estricta a la que nos describe Vitrubio $(\mathrm{V}, 11)$ y presenta el gimnasio helenístico de Priene (Ruiz de Arbulo 1995). En la primera mitad del siglo II a.C., los emporitanos levantaron una palestra o gimnasio.

Sabemos que en las ciudades griegas del Mediterráneo Oriental, los gimnasios eran instituciones públicas esenciales que garantizaban la formación intelectual, física y moral de los jovenes y de los ciudadanos. En las ciudades no griegas del amplio mundo helenístico, "los que van al gimnasio" era la forma de designar a los habitantes helénicos. En el siglo III a.C., Delos poseía tres palestras y un gimnasio (Audiat 1970). Las listas conservadas en este gimnasio muestran los mismos nombres familiares que aparecen en las necrópolis, es decir los residentes en la isla, pero no aparecen turistas ni peregrinos que sin embargo dejaron ofrendas votivas en los santuarios.

Empleando un lenguaje actual podríamos considerar la palestra o gimnasio emporitano un auténtico "club privado" reservado a la élite local. Una institución donde las reglas de la xenia y la philía permitirían quizás, como en el caso de la Massalia descrita por Estrabón, la atracción y "educación" de las nuevas élites del entorno provincial, gentes ibéricas y ahora también emigrantes itálicos: los labradores, pastores y hombres de negocios que describiera Cicerón en sus discursos forenses. Para un visitante procedente de Oriente existiría sin embargo un grave problema conceptual. La ley del gimnasio de Beroia, en Macedonia, excluía explícitamente de la institución en uno de sus preceptos "al esclavo, al liberto, a sus hijos, a las personas con defectos físicos, al prostituido, al borracho, al loco.... y a los que ejerzan un oficio de ágora" (Gauthier, Hatzopoulos 1993, cara B, 1. 26-29). Nuestra propuesta, en una ciudad denominada Emporion, reconoce evidentemente que estos preceptos "clásicos" debían ser sencillamente ignorados por una élite que basaba su riqueza no en la tierra, la ganadería y la guerra sino en la artesanía y el comercio marítimo. A no ser que la nueva situación política y el amplio territorio que ahora dependía de la ciudad hubiera formado una nueva élite social de emporitanos que se consideraban a sí mismos terratenientes agrícolas.

Con su producción de tejidos de lino como única actividad económica que describe Estrabón para los emporitanos, la ciudad suministraría también a las comunidades del entorno el gusto por las ropas finas que Ateneo habría tan injustamente criticado a los massaliotas. Pero el auge emporitano no fue solo producido por este comercio. El establecimiento del tributum provincial romano, los impuestos que todas las comunidades estipendiarias tenían que pagar anualmente, debían ser entregados y registrados por el magistrado o publicano responsable de su recogida. Y sabemos que estos impuestos, en las grandes zonas cerealísticas, se pagaban directamente en grano. Cicerón nos recuerda la trampa inventada por Verres en Sicilia, que consistía en fijar como puntos de recogida del impuesto en cereal aquellas ciudades en las que el precio del producto fuera más barato, pero anotando en los registros destinados al aerarium una compra con los precios más caros entonces vigentes en otros mercados de la isla. La diferencia entre ambos precios, que nuestros auditores de hoy en día denominarían "ingeniería contable", era una ganancia directa para el bolsillo del gobernador.

El sentido de la amistad romana y la amplitud de la chora emporitana tardo-republicana cobran así todo su sentido administrativo: los impuestos de Roma sustituyeron final y brutalmente al comercio culturizador del pasado. Un amplio campo de silos surgió en lo alto de la colina 
emporitana en torno al castrum romano, apareciendo a decenas bajo el foro de la nueva ciudad romana construida a fines del siglo II a.C.

Y la vida siguió su curso. A fines del siglo II a.C. se levantaría en lo alto de la colina emporitana una nueva ciudad de planta ortogonal, con un espacio urbano dividido en dos por una muralla intermedia (Ruiz de Arbulo 1998). Ampurias fue así durante unas décadas del siglo I a.C. una auténtica ciudad cuádruple, formada por dos ciudades contiguas cada una con una planta doble. Finalmente, la instalación de un contingente de veteranos cesarianos tras la batalla de Munda condujo a la fusión de ambas ciudades en un único municipio de nombre plural: Emporiae. Un pequeño templo, probablemente dedicado a César deificado se construyó presidiendo el recinto del gimnasio/palestra de la Neápolis. El ágora fue paulatinamente privatizada trasladándose la actividad pública al nuevo foro de la ciudad alta junto a la que se construyó un campus suburbano junto a la muralla sur. Personajes de nombre latino fueron ahora la nueva élite ciudadana. La Emporion greco-ibérica se había así, definitivamente, romanizado.

Tarragona, 12/07/04

\section{Bibliografía}

(Abreviaturas según la Archäologische Bibliographie)

Adroher, A.M., Pons, E. y Ruiz de Arbulo, J. 1993: El yacimiento de Mas Castellar de Pontós y el comercio del cereal ibérico en la zona de Emporion y Rhode (s. IV-II a.C.), ArchEspA, 66, Madrid, 31-70.

Agusti, B., Burch, J., Merino, J. 1995: Excavacions d urgencia a S. Julià de Ramis. Anys 1991-1993, Girona.

Agusti, B., Burch, J., Carrascal, C., Merino, J., NAVARRO, N. 1998: El reompliment de les sitges del Bosc del Congost, Cypsela, 12, 81-98.

AQUILUÉ X. (Dir.) et alii 1999: Intervencions arqueologiques a Sant Martí d Empuries (1994-1996). De l assentament precolonial a $l$ Empúries actual, Girona.

Aquilué X, Castanyer, P., Santos, M., Tremoleda, J. 2002: Nuevos datos acerca del hábitat arcaico de la Palaia Polis de Emporion, LUCE, J.M. (Coord.), Habitat et urbanisme dans le monde grec de la fin des palais myceniens à la prise de Milet, Pallas, 58, Toulouse, 301-327.

ArCelin, P. 1990: Arles, Voyage en Massalie. 100 ans d Archeologie en Gaule du Sud, Marseille, 195-201.

Arcelin, P., Dedet, B., Schwaller, M. 1992 : Espaces publics, espaces religieux protohistoriques en Gaule meridionale, Dossier Espaces et monuments publics protohistoriques de la Gaule méridionale, DocAMerid, 15, Lattes, 181-241.

Arribas, A. Y Trias, G. 1961 : Un interesante hallazgo cerrado en el yacimiento de Ullastret, ArchEspA, 34, Madrid, 18-40.

Asensio, D., Frances, J., Pons, E. 2002 : Les implicacions economiques i socials de la concentració de reserves de cereals a la Catalunya costanera en epoca iberica, Cypsela, 14, 125-140.

Audiat, J. 1970: Exploration Archeologique de Delos, 28. Le Gymnase, París.

Badie, A., Gailledrat, E., Moret, P., Ruillard, P., Sanchez, M.J., Sillieres, P. 2000: Le site antique de La Picola à Santa Pola (Alicante, Espagne), Madrid.

BARBET, A. 1991: Roquepertuse et la polychromie en Gaule meridionale, DocAMerid, 14, 53-81.

Bats, M., Bertucchi, G., Conges, G., Treziny, H. (Dirs y Eds.) 1992: Marseille Grecque et la Gaule (Marsella 1990), Etudes Massaliètes, 3, Aix-en-Provence.

Bell III, M. 1981: Morgantina Studies, I. The terracottas, Princeton.

BENOIT, F. 1955: Le sanctuaire aux esprits d'Entremont, CahLig, 4, 38-69.

1969: Gorgone et "tete coupee", du rite au mythe, ArchEspA, 42, 81-93.

BLECH, M. 1994: Terracotas de Ampurias, Iberos y griegos: lecturas desde la diversidad (Empuries 1991), Huelva, 87-113.

Brenot, C. (1990): La monnaie de Marseille, Marseille dans le Monde Antique, Les Dossiers d Archeologie, 154, 88-93.

Bresson, A. 1993: Les cités grecques et leurs emporia, BRESON, A. y ROUILLARD, P., L'Emporion, París, 163-226.

Bruneau, PH. 1970: Recherches sur les cultes de Delos à $l$ epoque hellenistique et à epoque romaine, Paris.

1978: Les cultes de l'etablissement des Poseidoniastes de Berytos à Delos, Hommages à Maarten J. Vermaseren, vol. I, 160-190.

Brunaux, J.L. 1989: Les os humains dans les sanctuaires Lateniens. Presentation; Les cranes humains sur les oppida. Extension de l'aire sacree aux limites de la ville, ambos en Dossier: Archeologie et rituel. Le point de vue sur les sanctuaires de La Tene, Les Nouvelles de l Archeologie, 35, 7-9 y 20.

(Dir.) 1991: Les Sanctuaires celtiques et le monde mediterraneen (St. Riquier 1990), Ed. Errance, París. 
BuRCH, J. 1996 a: L'emmagatzematge de cereals en sitjes depoca iberica al nord-est de Catalunya, tesis doctoral leida en la Univ. de Girona.

BuRCH, J. 1996 b : Ĺus de sitjes en epoca republicana al nord-est de Catalunya, RAPon, 6, 207-217.

Burch, J. 2000 : L'emmagatzematge en sitges durant l'epoca iberica, BUXÓ, R. y PONS, E. (Dirs.), Els productes alimentaris d origen vegetal a lEdat del Ferro de IEuropa Occidental: de la producció al consum (Girona 1999), Girona, 325-331.

Burch, J., Carrascal, C., Casellas, Ll.F., Merino, J., NAVARro, N. 1993 : Triptólemo. El culto a Deméter y los misterios eleusinos, Revista de Arqueología, 144, 40-45.

Burch, J., Nolla, J.M., Palahí, Ll., Sagrera, J., SuredA, M., VIVÓ, D. 2001: Excavacions arqueologiques a la muntanya de S. Julià de Ramis. 1. El sector de t antiga esglesia parroquial, Girona.

Buxo, R., Pons, E. y Vargas, A. 1998: El graner de l Empordà. Mas Castellar de Pontós a ledat del Ferro, Catálogo de Exposición, Girona.

Cabrera, P., Olmos, R., Sanmartí, E. (Eds.) 1994: Iberos y griegos: lecturas desde la diversidad, (Ampurias 1991), Huelva Arqueologica, 13, 2 vols., Huelva.

Cabrera, P. y SAntos, M. (Eds.) 2000: Ceramiques jonies depoca arcaica: centres de producció $i$ comercialització al Mediterrani Occidental, (Ampurias 1999), Monografies Emporitanes, 11, Barcelona.

CABrera; P. y SÁNCHEz, C. (Coords.) 2000: Los griegos en España. Tras las huellas de Heracles, Catal. Expos. MAN Madrid / MAC Barcelona, Madrid.

CAmpo, M., Sanmartí, E. (1994): Nuevos datos sobre la cronología de las monedas fraccionarias de Emporion (revisión del tesoro de la Neápolis 1926). Iberos y Griegos: lecturas desde la diversidad (Ampurias, 1991), Huelva Arqueologica, 13,1, 151-170.

CAPOT-Rey, R. 1956: Greniers domestiques et greniers fortifiés au Sahara. Le cas de Gourara, Trabaux de I Institut de Recherches Sahariennes d Alger, 14, 139-158.

Casas, S., Codina, F., Margall, J., de Prado, G. 2002: Noves aportacions al coneixement de l'ampliació nord de loppidum del Puig de S. Andreu (Ullastret). Estudi d'una inscripció sobre pedra trobada en aquesta zona, Cypsela, 14, 237-250.

CASELlas, S. 2002: Els macromamifers i la dieta carnica, PONS, E. (Dir.) et alii, Mas Castellar de Pontós (Alt Empordà). Un complex arqueologic depoca iberica (Excavacions 1990-1998), Monografies del Museu d'Arqueologia de Catalunya/Girona, 21, Girona, 483-498.
Castanyer, P., Santos, M., Tremoleda, J. 1999: Estudi de conjunt dels materials ceramics de les fases IIIa, IIIb i IIIc, AQUILUÉ X. (Dir.) et alii, Intervencions arqueologiques a Sant Martí d Empuries (1994-1996). De l assentament precolonial a lEmpúries actual, Girona, 231-276.

Castro, Z. 1979: Piezas discoidales en yacimientos ibéricos del NE de Catalunya, Cypsela, 2, 173-195.

Chabot, L. 1983: Lóoppidum de La Cloche aux PennesMirabeau (B. du Rh.), RANarb, 16, 39-80.

Chabot, L. y Feuguere, M. 1993: Les armes de l'oppidum de la Cloche et la destruction du site au Ier siecle avant notre ère, DocAMerid, 16, 337-351.

CiascA, A. 1988: Le protomi e le maschere, I Fenici, Catál. Expos. Venecia, Milán, 354-369.

Clinton, K. 1992: Myth and Cult. The iconograhy of the Eleusinian Mysteries, Estocolmo.

Conde, M.J. 1992: Una producció ceramica característica del mon iberic tardà: el kalathos "barret de copa", Fonaments, 8, 117-169.

Courby, F. 1922: Les vases grecs à reliefs, París.

Croisant, F. 1983: Les protomés féminines archaïques, BEFAR, 250, París.

Culican, W. 1976: Some phoenician Masks and other terracottas, Berytus, 24, 1975-, 47-87.

De Hoz, J. 1993: La lengua y la escritura ibéricas, y las lenguas de los íberos, Actas del V Coloquio, 635-666.

1994: Griegos e íberos: testimonios epigráficos de una cooperación mercantil, Iberos y griegos: lecturas desde la diversidad, (Ampurias 1991), Huelva Arqueologica, 13, 2 vols., Huelva, 245-271.

1999: Los negocios del señor Heronoiyos. Un documento mercantil, jonio clásico temprano, del sur de Francia, LOPEZ FREIRE, J.A. (Ed.) Desde los poemas homéricos hasta la prosa griega del siglo IV d.C. Veintiseis estudios filológicos, Ediciones Clásicas, Madrid, 61-90.

De la Fuente, P. 1998: Les fortificacions reials del golf de Roses en l epoca moderna, Col. Papers de Recerca, 3, Ajunt. de Roses, Figueres.

Derrotero 1945: Derrotero General del Mediterráneo, Madrid.

Despois, J. 1953: Greniers fortifiés de l'Afrique du Nord, Cahiers de Tunisie, 1, Tunez, 38-58.

DeYts, S. 1992: Images des dieux de la Gaule, París.

Domíngue Monedero, A. 2000: Los mecanismos del emporion en la práctica comercial de los foceos y otros griegos del Este, Ceramiques jonies depoca arcaica: centres de producció $i$ comercialització al Mediterrani 
Occidental, (Ampurias 1999), Monografies Emporitanes, 11, Barcelona, 27-45.

2001: La religión en el emporion, Gerion, 19, 221-257.

Fernández, M.J., Pons, E. Peces discoidals. Vasets votius-fireta, PONS, E. (Dir.) et alii 2002: Mas Castellar de Pontós (Alt Empordà). Un complex arqueologic depoca iberica (Excavacions 1990-1998), Monografies del Museu d'Arqueologia de Catalunya/Girona, 21, Girona, 375-380.

Ferrer, E. 2002: Topografía sagrada del extremo Occidente: santuarios, templos y lugares de culto de la Iberia púnica, Ex Oriente Lux: Las religiones orientales antiguas en la Península Ibérica, Sevilla, 185217.

GARCíA, D. 1987: Observations sur la production et le commerce des cereales en Languedoc méditerraneen durant l'Age du fer: les forme de stockage des grains, RANarb, 20, 43-98.

(ed.) 1992: AAVV, Dossier. Espaces et monuments publics protohistoriques de Gaule meridionale, Documents d Archeologie Meridionale, 15.

2000: Sistemas agrarios, cultivos de los cereales y urbanizacion en Galia meridional (s. VIII-IV a.C.), BUXO, R. y PONS, E. (Dirs.), Els productes alimentaris dorigen vegetal a lEdat del Ferro de lEuropa Occidental: de la producció al consum (Girona 1999), Girona, 189-196.

GARcíA, M. 2000: L'epigrafia amforica, PONS, E. (Dir.) et alii 2002, 565-575.

GaST, M. 1968: Alimentation des populations de l Ahaggar. Etude ethnografique, París.

Gauthier, Ph., Hatzopoulos, M.B. 1993: La Loi Gimnasiarchique de Beroia, Atenas.

Glanum 1989: AAVV, Glanum. Cité Grecque et Romaine de Provence, Les Dossiers de $t$ Archeologie, 140.

Gonzalo, C., López, A., Pons, E., Vargas, A. 2000: Producción y almacenamiento en la zona emporitana: Mas Castellar de Pontós, BUXO, R. y PONS, E. (Dirs.) Els productes alimentaris d origen vegetal a l Edat del Ferro de $l$ Europa Occidental: de la producció al consum (Girona 1999), Girona, 311-323.

Gracia, F. 1995: Producción y comercio de cereal en el N.E. de la Península Ibérica entre los siglos VII-II a.C., Pyrenae, 26, 91-113.

GrAS, M. 1987: Le temple de Diane sur l'Aventin, REA, 89, 46-61.

GUITART, J. 1975: Nuevas piezas de escultura prerromana en Cataluña: restos de un monumento con relieves en Sant Martí Sarroca (Barcelona), Pyrenae, 11, 7179.
Hausmann, U., 1959: Hellenistische Reliefbecher aus attischen und böottischen Werkstätten : Untersuchungen zur Zeitstellung und Bildüberlieferung, Stuttgart.

Hermary, A., Hesnard, A., Treziny, H. 1999: Marseille Grecque. La cité phoceenne (600-49 av. JC), París.

HoRn, F. 2003 : Les ceramiques pre-romaines à decor de têtes plastiques en Peninsule Iberique. Leur lien avec le rituel de la «tête coupée ", MelCasaVelázquez, 33-1, 275-314

IGAI: Rodríguez, H. 1998, Inscriptiones Graecae Antiquissimae Iberiae, MANGAS, J. y PLACIDO, D. (eds) La Peninsula Iberica en los autores griegos: de Homero a Platón, Madrid.

IRC III: FABre, G., MAYer, M., RodÀ, I. 1991: Inscriptions Romaines de Catalogne III. Gerone, París.

JaCQues-Meunie, Dj. 1951: Greniers-citadelle au Maroc, París (2 vols.).

JoAn-Treserras, J. 2002: Estudi dels residus organics per a la identificació de possibles ritus i ofrenes, PONS, E. (Dir.) et alii, Mas Castellar de Pontós (Alt Empordà). Un complex arqueologic depoca iberica (Excavacions 1990-1998), Monografies del Museu d'Arqueologia de Catalunya/Girona, 21, Girona, 548-556.

KAHIL, L. 1978: La deesse Artemis: Mythologie et iconographie, XI Classical Archaeological International Congress, (Londres, 1978), Londres, 73-87.

LAMONIER, L. 1977: Exploration archéologique de Délos. 31, La céramique hellénistique a reliefs. 1, Ateliers "ioniens", París.

Lejeune, M., Poullloux, J., Solier; Y. 1988: Etrusque et ionien archaiques sur un plomb de Pech Mahó (Aude), RANarb, 21, 19-59.

LLINAS, J. et alii 1998: La Perelada iberica i medieval segons l Arqueologia. Les excavacions de 1989 a 1995, Monografies Empordaneses, 4, Figueras.

MALUQUER, J. 1978: Els ibers: art, arquitectura, llengua i escriptura, Història de Catalunya, 1, Ed. salvat, Barcelona, 176-196.

Mar, R. y Ruiz de Arbulo, J. 1988: Sobre el agora de Emporion, AEspA, 61, 39-60.

1993: Ampurias Romana. Historia, Arquitectura y Arqueología, Ed. Ausa, Sabadell.

2001: El Serapeo en el contexto histórico de Ostia, MAR, R. (Dir.), El Santuario de Serapis en Ostia, Tarragona, 309-335.

Marcet, R. y Santimartí-Grego, E. 1989: Empuries, Barcelona.

Martin, A. 1977: Excavaciones de salvamento en el 
tramo de la autopista Gerona-Figueras, XIV Congreso Nacional de Arqueología (Vitoria 1975), Zaragoza, 1113-1123.

1978: Noticia de la troballa d'un motlle per a fabricar terracotes procedente de Roses, Revista de Girona, 85, 376-377.

1979: El yacimiento indígena preromano de Mas Castellar de Pontós (Girona), XV Congreso Nacional de Arqueología (Lugo 1977), Zaragoza, 677-690.

1983: Aportacions de les excavacions de Roses a l'estudi del comerç massaliota a l'Alt Empordà en els segles IV i III a.C., Cypsela, 4, 113-122.

1993: El iberismo en el nordeste de la Cataluña española, DocAMerid, 16, 14-18.

1998: Les cabanes enfonsades de l'Illa d’en Reixac: el poblament de la primera edat del Ferro a Ullastret, Baix Empordà, Cypsela, 12, 47-61.

2001: L'oppidum del Puig de San Andreu d'Ullastret. Aportació de les intervencions arqueologiques recents al coneixement dels sistemes defensius i de l'urbanisme, BUXÓ, R. y PONS, E. (Dirs.), L'Habitat protohistoric a Catalunya, Roselló $i$ Llenguadoc Occidental. Actualitat de l Arqueologia de lEdat del Ferro (Girona 2000), Girona, 107-121.

Martín, A, Buxo, R., López, J.B., Mataró, M., (Dirs.), 1999: Excavacions arqueologiques a tIlla den Reixac (1987-1992), Monografies d'Ullastret, Girona.

Martín, A. y Genis, M.T. 1998: El jaciments iberics del Puig de Serra (Serra de Darò). Segles VI- IV a.C., Estudis del Baix Empordà, 12, S. Feliu de Guixols, 548.

Martín, A, Mataro, M., Caravaca, J. 1998: Un edifici cultual de la segona mitad del segle III aC a l'Illa d'en Reixac (Ullastret, Girona), Espacios y lugares cultuales en el mundo ibérico, Quaderns de Prehistoria $i$ Arqueologia de Castelló, 18, 43-70.

Martín, A. y Plana, R. 2001: El nord-est catala en epoca iberica i l'entitat territorial de l'oppidum d'Ullastret, en MARTIN, A. y PLANA, R. (dirs.), Territori politic $i$ territori rural durante $l E d a t$ del ferro a la Mediterrania Occidental (Ullastret 2000), Monografies d'Ullastret, 2, Girona, 39-52.

Martín, A. y Puig, A.M. 2001: Rhode y loorganització del territori de l'Alt Empordà, en MARTIN, A. y PLANA, R. (dirs.), Territori politic i territori rural durante $I$ Edat del ferro a la Mediterrania Occidental (Ullastret 2000), Monografies d'Ullastret, 2, Girona, 53-68.

Martin, A. y Sanmartí, E. 1978: Aportación de las excavaciones de l'Illa d'en Reixach al conocimiento del fenomeno de la iberizacion en el norte de Cataluña,
El Origens del Mon Iberic (Barcelona-Ampurias 1977), Ampurias, 38-40, 431-447.

Martínez Gazquez, J. 1974: La campaña de Catón en Hispania, Barcelona.

Mele, A. (1979): Il commercio greco arcaico, prexis ed emporíe, Nápoles.

Miro, M. 1990: Les mascares del temple d'Ullastret, Zephyrus, 43, 305-309.

Moneo, T. 2000: Religio iberica. Santuarios, ritos y divinidades (siglos VI- I a.C.), Madrid.

Moret, P. 2002: Mastia Tarseion y el problema geográfico del segundo tratado entre Cartago y Roma, Mainake, 24, 257-276.

Moret, P. y Rouillard, P. 2000: La Picola aux Ve et IVe siecles av. J.C.: un port entre grecs et iberes, BADIE, A. et alii: Le site antique de La Picola à Santa Pola (Alicante, Espagne), Madrid, 255-265.

Mylonas, G.E. 1961: Eleusis and the eleusinian mysteries, Princeton.

Nieto, J. 1993: El edificio A de la Ciudadela de Roses. La Terra sigillata africana, Girona.

Nieto, J. y RAURICH, X. 1998: La infraestructura portuaria ampuritana, IIIJornades d Arqueologia Subaquatica, (Valencia 1997), Valencia, 57-76.

2003: Els treballs arqueològics subaquàtics al port romà d'Empuries, Tribuna d'Arqueologia 1999-2000, Barcelona, 165-178.

Oliva, M. 1955: Excavaciones arqueológicas del Plan Nacional en la ciudad indiketa o prerromana de Ullastret... Sexta campaña de trabajos, Anales del Instituto de Estudios Gerundenses, 10, 322-411.

1959: Excavaciones arqueológicas en la ciudad ibérica de Ullastret (Gerona)... Octava y Novena campaña de trabajos, Anales del Instituto de Estudios Gerundenses, 12, 319-337.

1967: Ullastret. Guía de las excavaciones y su Museo, Gerona.

OnRubia, J. 1986: Sellos y marcas de propiedad de graneros fortificados del Aures (Argelia). Consideraciones etnoarqueológicas en torno a las conexiones norteafricanas de las pintaderas de Gran Canaria, TrabPrehist, 43, 281-307.

Pagenstecher, R. 1909: Die calenische reliefkeramik, Berlín.

Pena, M.J. 1974: Artemis-Diana y algunas cuestiones en relación con su iconografía y su culto en Occidente, Ampurias, 35, 109-134.

1993: Terracotas votivas de Ampurias y Ullastret, Empuries, 48-50, vol. 2, 200-205. 
Perea, A., Aarmbruster, B., Demortier, G., Montero, I. 2003: Tecnología atlántica para dioses mediterráneos. Los candelabros de oro tipo Lebrija, TrabPrehist, 60-1, 99-114.

PiCARD, C. 1966: Etude sur les masques et rasoirs de Carthage, Karthago, 13, 1965-, 7-115.

Plana, R. 1994: La chora d Emporion. Paysage et structures agraires dans le Nord-Est catalan à la periode pré-romaine, ALUBesançon, 544, París.

Plana, R. y Martin, A. 2000: L'oppidum d'Ullastret et son territoire: premiers resultats, BUXO, R. y PONS, E. (Dirs.) ; L'Habitat protohistoric a Catalunya, Roselló $i$ Llenguadoc Occidental. Actualitat de r Arqueologia de lEdat del Ferro (Girona 2000), Girona, 123-134.

Plana, R. y Martin, A. 2001: L'organització de l'espai rural entorn de l'oppidum d'Ullastret: formes i dinamica del poblament, MARTIN, A. y PLANA, R. (dirs.), Territori politic i territori rural durante $l E d a t$ del ferro a la Mediterrania Occidental (Ullastret 2000), Monografies d'Ullastret, 2, Girona, 157-175.

Polignac, F. De 1984: La naisance de la cité grecque. Cultes, espaces et societé VIII-VII s. av. JC., París.

1990: Demeter ou l'alterité dans la fondation, DETIENNE, M. (Dir.), Tracés de Fondation, Lovaina-París, 289-299.

Pons, E, 1984: L'Empordà de lEdat del Bronze a lEdat del Ferro (1100-600 a.C.), Girona.

1997: Estructures, objectes i fets puntuals en el jaciment protohistoric de Mas Castellar (Pontós, Girona), Espacios y lugares cultuales en el mundo ibérico, Quaderns de Prehistoria i Arqueologia de Castelló, 18, 71-90.

Pons, E. et alii 2000: El establecimiento agrario de Mas Castellar de Pontós (s. III-II a.C.), BUXO, R. y PONS, E. (Dirs.) ; L'Habitat protohistoric a Catalunya, Roselló $i$ Llenguadoc Occidental. Actualitat de I Arqueologia de lEdat del Ferro (Girona 2000), Girona, 147-159.

Pons, E. (Dir.) et alii 2002: Mas Castellar de Pontós (Alt Empordà). Un complex arqueologic depoca iberica (Excavacions 1990-1998), Monografies del Museu d'Arqueologia de Catalunya/Girona, 21, Girona.

Pons, E. y Rovira, M.C. 1997: El diposit dofrenes de la fossa 101 de Mas Castellà de Pontós: un estudi interdisciplinari, Estudis Arqueologics,4, UdG, Girona.

Pons, E., Ruiz de Arbulo, J., Vivó, D. 1998: El yacimiento ibérico de Mas Castellar de Pontós (Girona). Análisis de algunas piezas significativas, ARANEGUI, C. (dir.), Los Iberos. Príncipes de Occidente (Barcelona 1998), Barcelona, 55-64.
Puig, A.M., Carrascal, C., Teixidor, M., Vieyra, G. 1996 : Els principals punts d'actuació al jaciment multiple de la Ciutadella de Roses, III Jornades d Arqueologia de les comarques de Girona (S. Coloma de Farnés 1996), Univ. de Girona, ed. fotocopiada, 242-251.

QUeSADA, F. 1997: El armamento ibérico. Estudio tipológico, geográfico, funcional, social y simbólico de las armas en la cultura ibérica (siglos VI-I a.C.), Montagnac.

Ramallo, S. 1993 a: Terracotas arquitectónicas del santuario de la Encarnación, (Caravaca, Murcia), ArchEspA, 66, 71-98.

1993 b : La monumentalización de los santuarios ibéricos en época tardo-republicana, Ostraka, 2, 1, 117-144.

RAMALlo, S. y BRotons, F. 1997 : El santuario ibérico de la Encarnación (Caravaca de la Cruz, Murcia), Espacios y lugares cultuales en el mundo ibérico, Quaderns de Prehistoria i Arqueologia de Castelló, 18, 257-268.

RIU, E. en prensa : L'Afrodision o Venus Pirinea. El santuari antic, Sant Pere de Rodes i la partició de Catalunya entre Espanya i França, RAPon, 14, Lleida.

Roth Conges, A. 1992 : Monuments publics d'époque tardo-hellénistique à Glanon (B.-du-Rh), Dossier Espaces et monuments publics protohistoriques de la Gaule méridionale, DocAMerid, 15, Lattes, 50-56.

Rotroff, S. 1987 : Megarian bowls in the Athenian Agora, Ann Arbor.

Rovira, C. 1998 : L'exhibició d'armes i cranis enclavats en els habitats ibers septentrionals, Cypsela, 12, 167182.

2002 : Els objectes metal.lics, PONS, E. (Dir.) et alii 2002: Mas Castellar de Pontós (Alt Empordà). Un complex arqueologic depoca iberica (Excavacions 19901998), Monografies del Museu d’Arqueologia de Catalunya/Girona, 21, Girona, 333-367.

Ruiz de Arbulo, J. 1984: Emporion y Rhode, dos asentamientos portuarios en el golfo de Roses, Arqueologia Espacial (Teruel 1984), vol. 4, 115-140.

1991: Rutas marítimas y colonizaciones en la Península Ibérica. Una aproximación náutica a algunos problemas, Cuadernos TEEHAR, 18, Madrid-Roma, 79-115.

1992: Emporion. Ciudad y territorio (s. VI-I a.C.). Algunas reflexiones preliminares, RAPon, 2, Lleida, 59-74.

1993: Contextos cerámicos de la primera mitad del siglo II a.C. en la Neápolis emporitana, Homenatge a $M$. Tarradell, Barcelona, 629-646.

1994 a: El gimnasio de Emporion, Butlleti Arqueologic, 16, Tarragona, 11-41. 
1994 b: Los cernos figurados con cabeza de Core. Nuevas propuestas en torno a su denominación, función y origen, Saguntum, 27, Valencia, 155-171.

1995 a: El santuario de Asklepios y las divinidades alejandrinas en la Neápolis de Ampurias (s. II-I a.C.). Nuevas hipótesis, Homenaje a A.M. Muñoz, Verdolay, 7, Murcia, 327-338.

1995 b: El gimnasio de Emporion, Butlleti Arqueologic, Tarragona, 11-44.

1996: Las asociación de jarras y palanganas de bronce tartesias e ibéricas. Una propuesta de interpretación, REIb, 2, 173-199.

1998 a: Rutas marítimas y tradiciones náuticas. Cuestiones en torno a las primeras navegaciones tirias al Mediterraneo Occidental, COSTA, B. y FERNANDEZ, J.H. (eds.), Rutas, navios y puertos fenicio-punicos, XI Jornadas de Arqueología FenicioPunica (Eivissa, 1996), Eivissa, 25-48.

1998 b: La evolucion urbana de Emporion en epoca tardo-republicana. La complejidad de una tradición, De les estructures indigenes a lorganització provincial romana de la Hispania citerior. Homenatge a J. Estrada, (Granollers 1987), Anexos Itaca, 1, Barcelona, 539554.

2000 : El papel de los santuarios en la colonización fenicia y griega de la Península Ibérica, XIV Jornadas de Arqueología Fenicio-púnica (Eivissa 1999), Eivissa, 956.

Salviat, F. 1993: La sculpture de Entremont, Archeologie dEntremont aux Musee Granet d Aix-en-Provence, 2 ed., Aix, 165-242.

SANMARTÍ-Grego, E. 1978 : La cerámica campaniense de Emporion y Rhode, 2 vols., Barcelona.

1992: Massalia et Emporion: une origine commune, deux destins differents, Marseille Grecque et la Gaule, Marsella, 27-41.

1993: Grecs et iberes à Emporion. Notes sur la population indigene de $1^{\prime}$ Empordà et des territoires limitrophes, DocAMerid, 16, 19-25.

Sanmartí-Grego, E., Castañer, P., Tremoleda, J.
1992: Nuevos datos sobre la historia y la topografía de las murallas de Emporion, MM, 33, 102-112.

Santiago, R.A. 1989: En torno al plomo de Pech Mahó, Faventia, 11/2, 163-179.

1995: Enigmas en torno a Saguntum y Rhoda, Faventia, $16 / 2,51-64$

Schroeder, S.F. 1996: El Asclepio de Ampurias ciuna estatua de Agathodaimon del ultimo cuarto del siglo II a.C.?, Actas de la II Reunion sobre escultura romana a Hispania (Tarragona 1995), Tarragona, 223-238.

SchWARZ, G. 1987: Triptolemos. Ikonographie einer Agrarund Mysteriengottheit, Horn-Graz.

SCODELlari, E. 2003: Le temple servien de l'Aventin: essai de réinterpretation des données traditionelles, Athenaeum, 91-2, 417-434.

Thompson, D. 1973: Ptolemaic Oinochoai and Portraits in Faience. Aspects of the ruler cult, Oxford.

UHLENBROCK, J.P. 1988: The terracotta protomai from Gela. A discussion of local style in Archaic Sicile, Roma.

VAn Berchem, D. 1960: Trois cas d'asylie archaique, Museum Helveticum, 17, 21-33.

Velissaropoulos, J. (1980): Les naucleres grecs. Recherches sur les institutions marítimes en Grece et dans lOrient hellenisé, Ginebra-París.

VilLA, A. 2003: Depósito funerario y recinto fortificado de la Edad del Bronce en el castro del Chao Sanmartín: argumentos para su datación, TrabPrehist, 60 / 2, 143-151.

Villard, F. 1960: Ceramique Grecque de Marseille. Essai d historire economique, París.

VIVÓ, D. 1996: Rhode. Arquitectura i urbanisme del barri hel.lenistic, RAPon, 6, Lleida, 81-117.

Voyage en Massalie 1990: AAVV, Voyage en Massalie. 100 Ans d Archeologie en Gaule du Sud, (Catal. Expos. Marsella 1990-91), Musees de Marseille, Marsella.

Zevi, F. Y Claridge, A. (Eds.) 1996: Roman Ostia revisited. Archeological and Historical Papers in Memory of $R$. Meiggs, Roma. 